\title{
AVALIAÇÃO DO PROCESSO DE SANIFICAÇÃO QUÍMICA NA LINHA DE PRODUÇÃO DE SALADAS CRUAS EM UM RESTAURANTE INDUSTRIAL
}

\author{
Maria laurentina Pereira Gomes Perdigão \\ Nutricionista
}

Orientador: Prof. Dr. ERNANI PORTO

\begin{abstract}
Dissertação apresentada à Escola Superior de Agricultura "Luiz de Queiroz", Universidade de São Paulo, para obtenção do título de Mestre em Ciências, Área de Concentração: Ciência e Tecnologia de Alimentos.
\end{abstract}

P I R A C I C A B A

Estado de São Paulo - Brasil

Agosto - 2004 
MARIA LAURENTINA PEREIRA GOMES PERDIGÃO. Avaliação do processo de sanificação química na linha de produção de saladas cruas em um restaurante industrial

\begin{tabular}{|c|c|c|c|}
\hline p. & item & linha & onde se le \\
\hline ix & RESUMO & quinta & ... foram em média de 1,46 ciclo $\log \ldots$ \\
\hline $\mathrm{ix}$ & RESUMO & $\begin{array}{l}\text { décima e décima } \\
\text { primeira }\end{array}$ & Em 8 das 14 análises ... \\
\hline $\mathrm{ix}$ & RESTMMO & décima terceira & ... mas consumia $7,68 \%$ do cloro. \\
\hline $\mathbf{x}$ & RESUMO & segunda e terceira & ... havendo redução de $28,1 \%$ de cloro livre. \\
\hline $\mathbf{x i}$ & SUMMARY & quinta & $\ldots$ an average of $1.46 \mathrm{log}$ cycles ... \\
\hline xi & SUMMARY & décima & ... in eight out of the 14 analyzes conducted. \\
\hline xi & SUMMARY & déeima segunda & ... consumed $7.68 \%$ of the chlorine. \\
\hline xii & SUMMARY & décima quinta & ... consumption ( $28,1 \%$ reduction) was observed.. \\
\hline 35 & 3.4 .2 & segunda. & ... concentraçôes dosadas à $200 \mathrm{mg} \mathrm{L}^{-1}$ de cloro livre ... \\
\hline 39 & 4.1 & $\begin{array}{l}\text { decima quarta e } \\
\text { décima quinta }\end{array}$ & $\begin{array}{l}\text {... de alface de } 1,46 \text { ciclo } \log \text {, acima das } \\
\text { relatadas, de năo mais do que } 1 \text { ciclo } \log \ldots\end{array}$ \\
\hline 40 & 4.1 & quarta & ... rabanete com redução de $>0,03$ ciclo $\log \ldots$ \\
\hline 41 & Figura 6 & $\begin{array}{l}\text { Coliformes } \\
\text { Totais }\end{array}$ & $\begin{array}{l}\text { Repolho / Lavado 2,19 Repolho / Redução 0,47 } \\
\text { Tomate /s/Lavar 1,19 Tomate / Lavado 0,52 } \\
\text { Rabanete / s/Lavar 2,94 Rabanete / Lavado 2,91 }\end{array}$ \\
\hline 41 & Figura 7 & E. coli & $\begin{array}{llc}\text { Alface / Lavada } & 0,53 \text { Alface / Redução } & 0,64 \\
\text { Repolho / s/Lavar } & 0,48 \text { Repolho / Lavado } & 0,70 \\
\text { Tomate / s/Lavar } & 0,48 \text { Tomate / Lavado } & 0,48 \\
\text { Rabanete / Lavado } & 0,48\end{array}$ \\
\hline 45 & 4.2 & segunda: & $\begin{array}{l}\text {.. pelo teor entre } 43 \text { a } 98 \mathrm{mg}^{-1} \text { de cloro livre em } 75 \% \\
\text { das amostras analisadas, ... }\end{array}$ \\
\hline 46 & 4.2; Tabela 1 & décima oitava & Média $\quad 97,18 \pm 33,32^{3} \quad 64,18 \quad 89,71 \pm 30,77 \quad 8,09$ \\
\hline 50 & 4.5 & primeira & ... identificaram $67 \%$ das amosiras $(26 \mathrm{em} 38) \ldots$ \\
\hline 50 & 4.5 & terceira & $\ldots$ apenas $20 \%(8 \mathrm{em} 38), \ldots$ \\
\hline 55 & 4.6.1; Tabela 6 & nona & Média $\begin{array}{llll}15,7 & 10,1 & -14,8 & -11,6\end{array}$ \\
\hline 56 & 4.6.; & quarta & $\ldots$ e $36,6 \%(r p)$ \\
\hline 59 & 4.6 .2 & nona & ... (Tabela 7$)$ \\
\hline 59 & 4.6 .2 & décima terceira & ... Tabela 11 \\
\hline 59 & 4.6 .2 & décima sexta & ... (Tabela 11). \\
\hline 65 & $\begin{array}{l}4.6 .5 \\
\text { Tabela } 14\end{array}$ & $\begin{array}{l}\text { primeira e } \\
\text { segunda }\end{array}$ & $\begin{array}{l}\text { Tabela 15. Estimativa de consumo de cloro livre } \\
\text { em soluções de } \mathrm{NaOCl} \text { e } \mathrm{NaDCC} \text { a } 200 \mathrm{Cl}_{2} \\
\mathrm{mgL}^{-1} \text { após terceiro em hortaliças }\end{array}$ \\
\hline 65 & $\begin{array}{l}4.6 .5 \\
\text { Tabela15 }\end{array}$ & $\begin{array}{l}\text { primeira e } \\
\text { segunda }\end{array}$ & $\begin{array}{l}\text { Tabela 16. Soluçôes remanescentes de } \mathrm{NaOCl} \text { e } \\
\mathrm{NaDCC} \text { a } 200 \mathrm{Cl}_{2} \mathrm{mgL}^{-1} \text { após terceiro } \mathrm{em} \\
\text { hortaliças }\end{array}$ \\
\hline 66 & 4.6 .5 & sétima e oitava & $\begin{array}{l}\text { Assim, a variação percentual de custo foi de } 0 \text { a } \\
79 \% \text { a mais para o NaDCC em relação à solução } \\
\text { de } \mathrm{NaOCl} \text { (Tabela 19). }\end{array}$ \\
\hline $\begin{array}{l}66 \mathrm{e} \\
67\end{array}$ & 4.6 .5 & $\begin{array}{l}\text { décima } \\
\text { primeira; } \\
\text { primeira a } \\
\text { terceira }\end{array}$ & $\begin{array}{l}\text { A diferença percentual de até } 79 \% \text { a menos no } \\
\text { custo do } \mathrm{NaOCl} \text { em relação ao } \mathrm{NaDCC} \\
\text { compensaria, inclusive, o maior consumo de } \\
\text { cloro ativo do } \mathrm{NaOCl} \text { em hortaliças fracionados, } \\
\text { em torno de } 18 \% \text {, após } 3 \text { usos da solução. }\end{array}$ \\
\hline 67 & $\begin{array}{l}\text { 4.6.5; } \\
\text { Tabela } 19\end{array}$ & $\begin{array}{l}\text { primeira e } \\
\text { segunda }\end{array}$ & $\begin{array}{l}\text { Tabela 19. Diferença percentual entre a relação de custo } \\
\text { por litro das soluções sanificantes a base de } \mathrm{NaOCl} \text { e... }\end{array}$ \\
\hline 67 & $\begin{array}{l}\text { 4.6.5: } \\
\text { Tabela } 19\end{array}$ & quarta a sétima & $\begin{array}{l}\text { Hipoclorito } 1 / \text { Dicloro }^{1} \\
74 \quad 0 \quad 79 \quad 19\end{array}$ \\
\hline 68 & CONCLUSÓES & quarta & ... a redução foi de 1,46 ciclos $\log$.. \\
\hline 68 & CONCLUSÖES & décima quarta. & ... o método titulométrico identificou $67 \%$ Em 8 de $14 \ldots$ \\
\hline 68 & CONCLUSOES & sétima & ... processo de sanificação. \\
\hline 69 & CONCLUSOES & sétima & ... soluçōes de hipoclorito de sódio ... \\
\hline 69 & CONCLUSŌES & nona & ... soluções de dicloroisocianurato de sódio ... \\
\hline 69 & CONCLUSÖES & $\begin{array}{l}\text { décima segunda } \\
\text { e décima } \\
\text { terceíra }\end{array}$ & $\begin{array}{l}\text {... de cloro ativo: } 31,2 \% \text { para hipoclorito de } \mathrm{Na} \text { e } \\
57,9 \% \text { para o dicloroisocianurato de } \mathrm{Na} \text { e maior } \\
\ldots\end{array}$ \\
\hline 69 & CONCUUSÕES & $\begin{array}{l}\text { vigésina } \mathrm{e} \\
\text { vigésima primeira }\end{array}$ & $\begin{array}{l}\text {... ap̣ós o } 3^{\circ} \text { wso de suras soluções, } 0,05 \mathrm{mg} \text { e } \\
0,071 \mathrm{mg} \text { de sujidades em soluçäo; }\end{array}$ \\
\hline 69 & CONCLUSÖES & vigésima segunda & ... o hipociorito de sódio foi ate $79 \%$ mais barato do \\
\hline
\end{tabular}

leia-se

... foram em média de 0,46 ciclo $\log .$.

Em 26 das 38 análises...

... mas consumiu $7,47 \%$ do cloro.

... havendo reduçẫo de cloro livre, em média, de $50,5 \%$

$\ldots$ an average of 0.46 log cycles ...

... in twenty six out of the $\mathbf{3 8}$ analyzes conducted.

... consumed $7.47 \%$ of the chlorine.

... consumption ( $50,5 \%$ reduction) was observed ...

... concentrações determinadas de cloro livie...

... de alface de 0,46 ciclo log, abaixo das contagens

relatadas de até 1 ciclo $\log . .$.

... rabanete com redução de 0,03 ciclo $\log$...

Repolho / Lavado <2,19Repolho / Redução $>0,47$

Tomate /. s/Lavar $<0,19$ Tomate / Lavado $<0,52$

Rabanete / $\mathrm{s} /$ Lavar $\geq 2,94$ Rabanete / Lavado $\geq 2,91$

Alface/ Lavada $<0,56$ Alface/ Redução $>0,61$

Repolho/s/Lavar $<0,48$ Repolho/Lavado $<0,70$

Tomate $/$ s/Lavar $<0,48$ Tomate / Lavado $<0,48$

Rabanete / Lavado $<0,48$

pelo teor médio de cloro livre a $97 \mathrm{mgL}^{-1}$ nas amostras iniciais e $90 \mathrm{mgL}^{-1}$ nas amostras finais aralisadas, ..

Média $\quad 97,18 \pm 33_{3}, 3264,18 \quad 89,71 \pm 30,77^{3} \cdot 7,47$

... identificaram $68 \%$ das amostras (26 em 38 ) ...

... apenas $21 \%(8 \mathrm{em} 38), \ldots$

Média $15,7 \quad 10,1$

$14,8 \quad 11,6$

... e $36,3 \%$ (rp).

... (Tabelas 11 - 12).

... Tabelas 11 e 12 .

... (Tabelas 11 e 12)

Tabela 15. Estimativa de Redução absoluta e percentual de cloro livre em soluções teóricas de $\mathrm{NaOCl}$ e $\mathrm{NaDCC}$ a 200 $\mathrm{Cl}_{2}$ mgL $^{-1}$ após terceiro uso na sanificação de hortaliças

Tabela 16. Estimativa de cloro livre em soluçồes teóricas de $\mathrm{NaOCl}$ e $\mathrm{NaDCC}$ a $200 \mathrm{Cl}_{2} \mathrm{mgL}^{-1}$ após o terceiro uso na sanificação de hortaliças

Assim, a diferença de custo entre as soluções foi de 0 a $367 \%$ maior para as soluções de $\mathrm{NaDCC}$ em relação ao custo das soluções de $\mathrm{NaOCl}$ (Tabela 19). O menor custo das soluções de $\mathrm{NaOCl}$ em relaçâo às soluçōes de $\mathrm{NaDCC}$ em até $367 \%$ compensaria, inclusive, o maior consumo de cloro livvre nas soluções $\mathrm{NaOCl}$ em hortaliças fracionados (Tabela 15)

Tabela 19. Diferença de custo absoluta e percentual de soluções a base de $\mathrm{NaOCl} \mathrm{e} . .$.

Hipoclorito ${ }^{1}$ - Dicloro ${ }^{1}$ $-0,025-278 / 0 \ldots 0 /-0,033 \ldots-367 /-0,008-23$

... a redução foi de 0,46 ciclo $\log$...

.. o método títulamétrico identificou $68 \%$ Em 26 das 38 ..

... processo de sanificação da alface

... soluçốes de dicloroisocianurato de sódio.

... soluçẽes de hipoclorito de sódio ...

... de cloro livre ao final do terceiro uso das soluçōes: $31,2 \%$ para dicloroisociamurato de sódio $57,9 \%$ para o hipoclorito de sódio, além de levar a uma maior reduçăo do pH (1.8).

... ajós $3^{\circ}$ uso acumularam, respectivamente,

$17 \mathrm{mg} \mathrm{L}^{-1}$ e $25 \mathrm{mgL}^{-1}$ de sujidades;

... as soluções de hipoclorito de sódio foram até $367 \% \mathrm{~m}$ baratas do que as soluções de dicloroisocianurato de só́ 
Dados Internacionais de Catalogação na Publicação (CIP) DIVISÃO DE BIBLIOTECA E DOCUMENTAÇÃO - ESALQ/USP

\section{Perdigão, Maria Laurentina Pereira Gomes}

Avaliação do processo de sanificação química na linha de produção de saladas cruas em um restaurante industrial / Maria Laurentina Pereira Gomes Perdigão. - Piracicaba, 2004.

91 p.: il.

Dissertação (mestrado) - - Escola Superior de Agricultura Luiz de Queiroz, 2004. Bibliografia.

1. Higiene dos alimentos 2. Hortaliças 3. Refeições 4. Restaurantes 5. Saladas

6. Segurança alimentar I. Título

CDD 664.8

"Permitida a copla totalou parcialyes te doctmento desdevaue citada a fonte - O autor" 
Aos meus pais,

Adélio e Lodovina

pelo exemplo de luta .

Às minhas irmãs

Maria Madalena e Maria Paula

pelo exemplo de dedicação

Ao Douglas pelo companheirismo e amor.

Aos meus filhos Vinicius e Luiza.

Dedico e ofereço 


\section{AGRADECIMENTOS}

Ao meu orientador, Prof. Dr. Ernani Porto, pelos ensinamentos, orientação, e apoio na realização deste trabalho.

À Universidade Federal de São Carlos, em especial ao Sr. Marco Antonio Zanni, Secretário de Assuntos Comunitários, pela valorização e incentivo à formação técnicoacadêmica.

À nutricionista Maria Sylvia Carvalho de Barros e aos demais funcionários do Restaurante Universitário da UFSCar, pelo apoio dado durante o período do meu afastamento para o mestrado.

À nutricionista do Restaurante Universitário da ESALQ/USP, Maria Luisa L. S. Campos, por propiciar e disponibilizar todos os recursos para a realização deste trabalho e aos demais funcionários, pela receptividade.

Aos membros da Banca Examinadora, pelas valiosas contribuições e sugestões apresentadas.

À Emanuella e Tarsila, futuras nutricionistas e estagiárias da sessão de Microbiologia de Alimentos da ESALQ/USP, pela grande colaboração prática na realização deste trabalho. 
À amiga Marina Vieira da Silva, profa. do Departamento de Agroindústria, Alimentos e Nutrição da ESALQ/USP, pelo estímulo e apoio dado durante o mestrado.

À amiga Emanuella Trevisan, pela presença, carinho e dedicação.

Aos colegas do mestrado por termos compartilhando as mesmas dificuldades e conseguido vencer todas.

Às Técnicas de laboratório da sessão de Microbiologia de Alimentos, Cecília, Cleomar, Denise e Rose, pelo apóio dado durante o período de realização deste trabalho.

À técnica de laboratório Sheila Roberta Wenzel Perdigão e ao Prof. Dr. Boaventura Freire dos Reis da sessão de Química Analítica do Centro de Energia Nuclear na Agricultura (CENA/USP).

Ao Prof. Dr. Cláudio Gallo, pelos ensinamentos de Microbiologia

À equipe da biblioteca setorial do Departamento de Agroindústria Alimentos e Nutrição pelo trabalho sempre dedicado.

À todos os docentes e funcionários do Departamento de Agroindústria Alimentos e Nutrição da ESALQ/USP.

A Deus e Mãe Maria a quem sempre peço luz, força e proteção. 


\section{SUMÁRIO}

Página

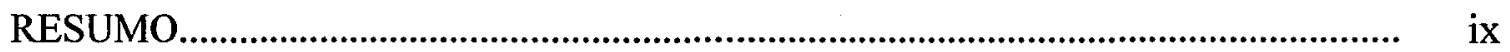

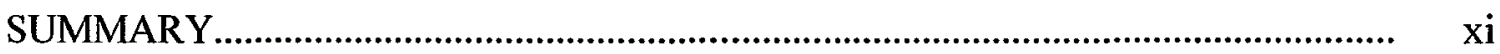

1 INTRODUÇÃO................................................................................................. 1

2 REVISÃO DE LITERATURA.......................................................................... 3

2.1 Hortaliças na alimentação e nutrição humana................................................................ 3

2.2 Alimentação e refeições coletivas..............................................................................

2.3 Microbiologia de hortaliças e as doenças de origem alimentar.................................... 4

2.4 Microrganismos indicadores de qualidade higiênico-sanitária...................................... 5

2.4.1 Contagem total de bactérias aeróbias mesófilas....................................................... 6

2.4.2 Contagem de coliformes totais.................................................................................... 6

2.4.3 Contagem de coliformes fecais................................................................................. 7

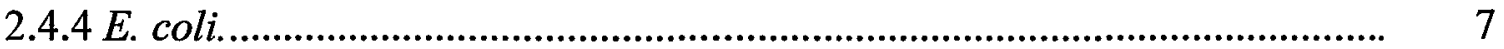

2.5 Higiene e o processamento de alimentos....................................................................... 8

2.6 Sanificantes químicos.......................................................................................... 10

2.7 Sanificação química e eficiência microbicida ............................................................. 15

2.8 Sanificação química e a higiene dos alimentos........................................................ 19

2.9 Sanificação química na linha de processamento de hortaliças................................ 20

2.10 Compostos sanificantes clorados e a segurança alimentar...................................... 22

3 MATERIAL E MÉTODOS................................................................................ 24

3.1 Descriçãa do local...................................................................................................... 24

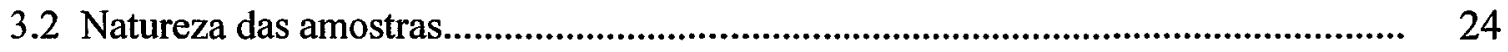

3.3 Fluxo de produção de saladas cruas.......................................................................... 25

3.4 Planejamento experimental .............................................................................. 26 
3.4.1 Qualidade microbiológica inicial e eficiência do procedimento de lavagem e sanificação de hortaliças

3.4.1.1 Preparo das amostras para as análises microbiológicas.

3.4.1.1.1 Determinação da contagem total de microrganismos aeróbios mesófilos...... 31

3.4.1.1.2 Determinação da contagem de coliformes totais............................................... 31

3.4.1.1.3 Determinação da contagem de E.coli.......................................................... 32

3.4.1.2 Preparo das amostras para as determinações químicas......................................... 33

3.4.1.2.1 Solução Clorada................................................................................................. 33

3.4.1.2.1.1 Determinação de cloro livre............................................................................. 34

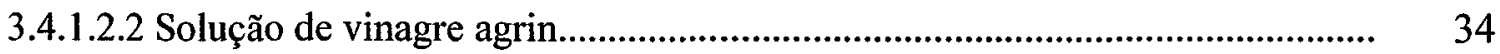

3.4.1.2.2.1 Determinação de $\mathrm{pH}$....................................................................................... 34

3.4.1.2.2.2 Determinação de acidez total e em ácido acético............................................ 35

3.4.1.3 Dosagem de cloro livre pelo uso do kit colorimétrico.......................................... 35

3.4.2 Estudo laboratorial sobre o comportamento de soluções a base de dicloroisocianurato de sódio e hipoclorito de sódio na sanificação de hortaliças........................................................................................................... 35

3.4.2.1 Preparo das amostras.................................................................................. 36

3.4.2.2 Determinações de cloro livre e pH.............................................................. 36

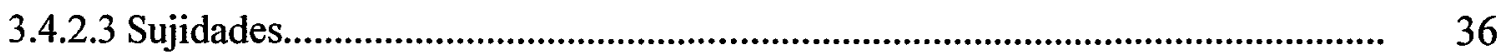

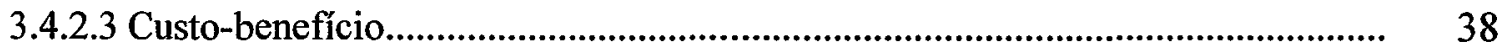

4 RESULTADOS E DISCUSSÃO................................................................. 39

4.1 Qualidade sanitária inicial de hortaliças e eficiência da lavagem.......................... 39

4.2 Eficácia da sanificação em alface......................................................................... 42

4.3 Eficácia do tratamento complementar com solução de vinagre agrin em alface sanificada.

4.5 Avaliação do kit dosador de cloro livre como instrumento de monitoração do teor crítico de cloro livre em soluções.

4.6 Estudo laboratorial com soluções sanificantes no tratamento de hortaliças

4.6.1 Cloro livre........................................................................................................ 52

4.6.2 $\mathrm{pH}$. 
4.6.3 Cloro livre e pH em soluções de hipoclorito de sódio sob condições habituais de processamento na produção de saladas cruas.

4.6.4 Sujidades em soluções pós-sanificação......................................................... 64

4.6.5 Custo-benefício da sanificação em hortaliças.................................................... 64

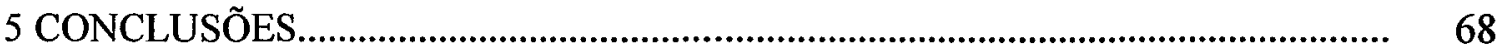

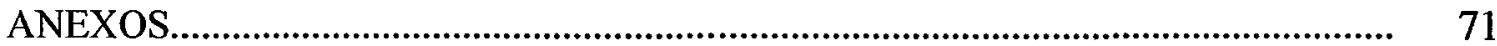

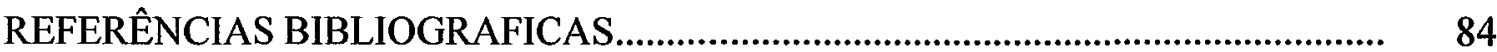




\title{
AVALIAÇÃo DO PROCESSO DE SANIFICAÇÃO QUÍMICA NA LINHA DE PRODUÇÃO DE SALADAS CRUAS \\ EM UM RESTAURANTE INDUSTRIAL
}

\author{
Autora: MARIA LAURENTINA PEREIRA GOMES PERDIGÃO \\ Orientador: Prof. Dr. ERNANI PORTO
}

\section{RESUMO}

Foi feito estudo do processo de sanificação de hortaliças no Restaurante Universitário da Escola Superior de Agricultura "Luiz de Queiroz". Foram analisadas as hortaliças recebidas, antes e após a lavagem, antes e após a sanificação e prontas para servir. Todas as amostras analisadas estiveram dentro dos padrões da portaria ANVISA RDC 12/2001. As reduções obtidas na lavagem da alface foram em média de 1,46 ciclo log para mesófilos totais e Escherichia coli abaixo do limite de deteç̧ão. O processo completo de sanificação com dicloroisocianurato de $\mathrm{Na}$ foi eficiente no caso, reduzindo a população de mesófilos em 1,0 ciclo logarítmico e 0,12 ciclo logarítmico para E. coli. O enxágüe com solução de vinagre não contribuiu para a redução bacteriana. O kit de dosagem de cloro utilizado no restaurante falhou na detecção das concentrações críticas de $100 \mathrm{mg} \mathrm{L}^{-1}$. Em 8 das 14 análises ficou demonstrado que a concentração de cloro esteve abaixo do previsto pela legislação. A reutilização das soluções sanificantes não afetou sua eficiência sobre a redução bacteriana, mas consumiu $7,68 \%$ do cloro. Foi também estudado laboratorialmente o comportamento de 2 sanificantes à base de cloro: hipoclorito de sódio a e Dicloroisocianurato de sódio frente ao processo utilizado: vegetais inteiros e fracionados e três reutilizações. $O$ 
hipoclorito de sódio foi o que teve maior consumo, quando utilizado em vegetais fracionados, havendo redução de $28,1 \%$ de cloro livre. Nos vegetais inteiros não houve diferenças entre os 2 produtos, mas no geral o dicloroisocianurato foi menos consumido durante os processos. 0 sanificante hipoclorito de sódio foi mais afetado durante o processo de sanificação do que o dicloroisocianurato de sódio. Por outro lado, seus custos são mais reduzidos. 


\title{
VALUATION OF THE CHEMICAL SANITIZING PROCESS IN THE PRODUCTION LINE OF RAW SALADS IN AN INDUSTRIAL RESTAURANT
}

\author{
Author: MARIA LAURENTINA PEREIRA GOMES PERDIGÃO \\ Adviser: Prof. Dr. ERNANI PORTO
}

\section{SUMMARY}

A study on vegetables sanitization process was carried out at the campus restaurant of the "Luiz de Queiroz" Agronomy College. Vegetables were inspected before and after washing, before and after sanitization, and when ready to be served. All analyzed samples complied with ANVISA RDC 12/2001 Brazilian sanitary standards. Washing lettuce reduced total mesofilic microorganisms by an average of $1.46 \mathrm{log}$ cycles and Escherichia coli to levels below detection. Complete sanitization with Sodium Dichloro Isocyanurate was effective in this study, reducing mesofilic population by $1.0 \log$ cycle and E. coli by $0.12 \log$ cycle. Rinsing with vinegar solution did not reduce the bacterial population. The chlorine dosage kit used failed to detect critical concentrations of $100 \mathrm{mg} \mathrm{L}^{-1}$. Chlorine concentrations were below legal standards in eight out of the 14 analyzes conducted. The reuse of sanitization solutions did not affect their efficiency at reducing the bacterial population, but consumed $7.68 \%$ of the chlorine. A laboratorial studied was also carried out on the performance of two chlorine-based sanitizing solutions (Sodium Hypochlorite and Sodium Dichloro Isocyanurate) under two processing procedures (whole or cut vegetables) and three reuses of the sanitizing solution. The highest solution consumption ( $28.1 \%$ reduction) was observed for Sodium Hypochlorite in cut vegetables. No differences between the two solution consumptions were observed for whole vegetables, although there was lower overall Dichloro Isocyanurate consumption during the processes. Sodium Hypochlorite was more 
affected during the sanitizing process than Sodium Dichloro Isocyanurate. On the other hand, the use of this solution resulted in lower sanitizing costs. 


\section{INTRODUÇÃO}

Mudanças no hábito alimentar surgiram nas últimas décadas, em função da necessidade do controle das doenças crônico-degenerativas, juntamente com o apelo estético à boa forma e qualidade de vida.

Adequando-se cada vez mais aos desejos dos consumidores, são oferecidas opções variadas de cardápios, e as saladas têm atendido a esta necessidade de diversificação e novidade, com a inclusão de novos ingredientes, tornando-as ainda mais apreciáveis.

Dificuldades no controle sanitário de produtos hortícolas, quanto às medidas que evitem a contaminação acima do aceitável ao longo da cadeia de produção - no campo, durante o transporte, armazenamento e comercialização, justificam a sanificação química como etapa fundamental dentre as boas práticas de fabricação para a qualidade sanitária das hortaliças consumidas cruas, segundo critérios técnicos estabelecidos pela portaria da Comissão de Vigilância Sanitária da Secretaria de Estado da Saúde de São Paulo (CVS/SES-SP) (1999).

O hipoclorito de sódio e o cloro orgânico são os únicos sanificantes aprovados, por legislação, em alimentos, contudo alternativas começam a ser pesquisadas, visando a estudar a eficiência do ponto de vista microbiológico e sensorial.

O conhecimento da eficácia dos procedimentos adotados durante o processo de sanificação, com base em uma linha de produção de saladas, pode trazer importantes contribuições para o controle deste ponto crítico. 
Assim, com a crescente preocupação com a segurança alimentar, inclusive quanto ao aspecto qualitativo, espera-se que os resultados da pesquisa subsidiem administradores e técnicos de serviços de alimentação, entre outros, na avaliação do procedimento de sanificação de hortaliças servidas cruas, otimizando-o, passando inclusive pela avaliação do custo-benefício do sanificante empregado. 


\section{REVISÃO DE LITERATURA}

\subsection{Hortaliças na alimentação e nutrição humana}

A Comissão Nacional de Normas e Padrões para Alimentos - CNNPA (Brasil, 1978) define hortaliça como planta herbácea da qual uma ou mais partes são utilizadas como alimento na sua forma natural, sendo designada verdura, quando utilizadas as partes verdes; legumes, quando utilizado o fruto ou a semente, especialmente das leguminosas e, raízes, tubérculos e rizomas, quando utilizadas partes subterrâneas. São classificadas em extra, de primeira, de segunda, de acordo com graus relativos ao estado de desenvolvimento, firmeza, coloração, defeitos e danos físicos e/ou mecânicos.

As hortaliças são essenciais para uma dieta equilibrada em macro e micro nutrientes. Pesquisas em nutrição humana indicam que o consumo de frutas e hortaliças ajuda na prevenção e redução de doenças, incluído as crônico-degenerativas com alta prevalência nos países desenvolvidos e em desenvolvimento, em função de sua composição em fibras, baixo teor em sódio e ação nutracêutica (Mazza, 2000).

Nos Estados Unidos, durante a década de 1990, o consumo per capita anual aumentou, em média, 13\%, em relação à década anterior, muito em função dos produtos minimamente processados como saladas (Meng \& Doyle, 2002).

No Brasil, a disponibilidade de frutas e hortaliças tem aumentado da mesma forma que o consumo de frutas e de produtos frescos, devido à necessidade de se adequar a alimentação a menores teores de colesterol, gordura, sal e outras substâncias que possam causar danos a saúde (Neves et al., 2000). 


\subsection{Alimentação e refeições coletivas}

A partir da década de 90 , no Brasil, verifica-se mudança em relação ao consumo de refeições fora do domicílio pela grande expansão dos fast food ( $30 \%$ ao ano, durante os anos 90), de restaurantes "por quilo", empresas de serviços de alimentação, (inclusive atendendo ao PAT - Programa de Alimentação do Trabalhador) e caterers (refeições em aviões, aeroportos, trens e outros). $\mathrm{O}$ número de estabelecimentos de refeições coletivas praticamente dobrou entre 1991 e 1998, servindo 38 milhões de refeições diárias (Neves et al., 2000).

\subsection{Microbiologia de hortaliças e as doenças de origem alimentar}

As bactérias deteriorantes (pecticnolíticas), leveduras e bolores filamentosos formam a microbiota dominante das hortaliças. Espécies patogênicas podem ocorrer devido ao uso de água de irrigação contaminada, esterco e vegetais indevidamente compostados ou como conseqüência da má higiene durante o transporte, armazenamento e processamento (Beuchat, 2002; Oliveira \& Valle, 2000). Sobrevivência e crescimento de patógenos humanos têm sido demonstrados em produtos frescos (Meng \& Doyle, 2002).

Meng \& Doyle (2002) citam dados da Organização Mundial da Saúde (OMS), em que centenas de milhões de pessoas em todo o mundo sofrem de doenças causadas por alimentos contaminados, e dados do Centro de Prevenção e Controle de Doenças dos Estados Unidos (CDC), que indicam que as doenças de origem alimentar causam aproximadamente 76 milhões de doentes, 325.000 hospitalizações e 5000 mortes a cada ano só nos Estados Unidos.

O número de casos confirmados de doenças associadas ans consumos de frutas e hortaliças cruas é menor em comparação ao número de casos por consumo de produtos de origem animal. No entanto, as doenças de origem alimentar associadas a frutas e vegetais crus tiveram frequiência aumentada durante a última década, associadas 
a mudanças nas práticas agronômicas e de processamento, aumento per capita de produtos frescos minimamente processados, incremento do comércio internacional e da distribuição e ao aumento do número de consumidores imuno-comprometidos (Beuchat, 2002; Meng \& Doyle, 2002).

A Agência Nacional de Vigilância Sanitária (ANVISA), segundo a Comissão Nacional de Normas e Padrões para Alimentos (CNNPA) (Brasil, 1978), regulamenta a comercialização de hortaliças através de critérios gerais (cultivo, colheita, etc), microbiológicos e microscópicas para a avaliação dos produtos próprios para o consumo.

Nogueira \& Chocken-Iturrino (2002), avaliando as condições higiênicosanitárias de 35 hortas do município de Jaboticabal-SP, constataram que no período chuvoso, quando há maior possibilidades de contaminações, 17,9\% das amostras avaliadas de hortaliças após tratamento de lavagem, estavam em desacordo com a legislação e que no período seco a freqüência caiu para $6,7 \%$.

Takayanagui et al. (2001) avaliaram a microbiota de verduras como a alface, almeirão, rúcula, agrião e chicória, comercializadas no município de Ribeirão Preto, SP, em todos os pontos de venda ao consumidor, num total de 172 estabelecimentos, e os resultados do exame microbiológico revelaram que $63 \%$ das amostras com população de coliformes fecais acima do máximo permitido pela legislação e presença de Salmonella em 9\%. O tipo de contaminação apresentou distribuição uniforme em relação ao tipo de estabelecimento comercial e à variedade da verdura avaliada.

\subsection{Microrganismos indicadores de qualidade higiênico-sanitária}

A grande variedade de microrganismos nos vegetais reflete freqüentemente a microbiota presente no campo no momento da colheita. Determinantes climáticos e agrícolas afetam o ecossistema microbiano, incluídos a localização geográfica, o histórico de precipitações, vento, práticas de irrigação, práticas de pré-colheita, colheita 
e pós-colheita, a presença de insetos, animais e pássaros. As bactérias Gram-negativas dominam a microbiota associada com a maioria dos vegetais (Beuchat, 2002).

A microbiota presente nas hortaliças não significa necessariamente um perigo para o consumidor ou um comprometimento de sua qualidade. No entanto, quando submetidas a condições que permitam a contaminação e/ou multiplicação de agentes infecciosos ou toxigênicos, podem se tornar veículos de transmissão de doenças (International Commission on Microbiological Specification for Food) (ICMSF) (1995).

Os microrganismos indicadores são pertencentes a grupos ou espécies, cuja enumeração ou contagem é feita com maior facilidade do que seriam os métodos específicos para a identificação das espécies de patógenos, que a um determinado número, de acordo com o tipo de alimento, indicam se o alimento foi exposto a condições de risco sanitário (ICMSF, 1995).

\subsubsection{Contagem total de bactérias aeróbias mesófilas}

É o método mais comumente utilizado para indicar, de uma forma geral, a qualidade sanitária dos alimentos. A maioria das bactérias patogênicas é mesófila, e a alta contagem em placas indica uma maior probabilidade da presença destas. Contudo, para alimentos in natura é um indicador que reflete mais a contaminação do ambiente do que propriamente riscos (ICMSF, 1995).

\subsubsection{Contagem de coliformes totais}

São bactérias da família Enterobacteriaceae, capazes de fermentar a lactose, com produção de gás, quando incubadas a $35-37^{\circ} \mathrm{C}$ por $48 \mathrm{~h}$. São bastonetes Gramnegativos, não formadores de esporos. Quatros gêneros formam este grupo: Escherichia, Enterobacter, Citrobacter e Klebsiella. Estão presentes no solo, vegetais e nas fezes. No entanto, apenas a espécie Escherichia coli faz parte do trato gastrintestinal do homem e de animais de sangue quente (ICMSF, 1995). 
É um indicador muito utilizado na avaliação sanitária de alimentos, exigindo condições instaladas em termos de material e equipamentos menos complexas do que seriam a identificação e quantificação dos patógenos envolvidos em surtos de toxinfecções alimentares.

\subsubsection{Contagem de coliformes fecais}

Os coliformes fecais são capazes de fermentar a lactose, com produção de gás, quando incubados a $44-45,5^{\circ} \mathrm{C}$, dependendo do método. Nestas condições, incluem-se 90\% das E.coli e algumas cepas de Enterobacter e Klebsiella, o que o torna um bom indicador de qualidade sanitária (ICMSF, 1995).

A ANVISA (Brasil, 2001) estabelece para o grupo de hortaliças frescas in natura, preparadas (descascadas, selecionadas ou fracionadas), sanificadas, refrigeradas ou congeladas para consumo direto, com exceção de cogumelos, contagem de $100\left(10^{2}\right)$ $\mathrm{NMP} / \mathrm{g}$ de coliformes a $45,5^{\circ} \mathrm{C}$ como parâmetro tolerável de qualidade sanitária para amostras indicativas.

\subsubsection{E. coli}

É o único microrganismo indicador válido na análise dos alimentos vegetais frescos. A presença deste microrganismo nos alimentos indica geralmente uma contaminação direta ou indireta de origem fecal. Sua presença não significa necessariamente a presença de patógenos, e sim um risco (ICMSF, 1995).

O meio LST-MUG (caldo lauril triptose complementado com $50 \mathrm{mg} / \mathrm{L}$ de ácido 4-metilumbeliferil-beta-D-glucoronídeo - MUG) é um meio rápido para a determinação da $E$. coli já que $94 \%$ são produtoras da enzima beta-glucoronidase (GUD) que ao clivar a molécula do MUG, produz o 4-metilumbeliferil, substância fluorogênica quando submetida à luz ultravioleta $365 \mathrm{~nm}$ em câmara escura (APHA, 1992; Silva, 2001). 


\subsection{Higiene e o processamento de alimentos}

A higiene dos alimentos busca conservar ou promover a saúde, assegurando a sua inocuidade e sanidade. Em qualquer estudo sobre higiene alimentar é fundamental o conhecimento do que é contaminação e as formas de como pode ser controlada.

A contaminação pode ser provocada por agentes físicos, químicos ou biológicos. A biológica é originada por seres vivos nos alimentos que, quando capazes de provocar enfermidades, são denominados de patógenos. Os alimentos podem conter um elevado número de patógenos sem que aparentem estar contaminados. As bactérias são os contaminantes biológicos mais importantes nos alimentos (Johns, 1995).

As bactérias abundam o solo e os excrementos humanos e animais, estando presentes no intestino e sobre a pele destes. Algumas espécies de bactérias podem produzir toxinas no interior do organismo e outras várias são capazes de crescer e multiplicar-se nos alimentos, causando distúrbios gastrintestinais e, em casos de infecção intensa, podem invadir órgãos e as correntes sanguíneas, causando enfermidades graves que podem levar à morte (Johns, 1995).

Os contaminantes biológicos se encontram presentes na maioria dos alimentos crus e devem ser tratados de alguma maneira para que, se contaminados, não se tornem veículos de toxinfecção alimentar. Os alimentos submetidos a um processo de produção podem chegar a ser veículos de enfermidade, principalmente quando o contaminante presente no alimento sobrevive ao processo de produção; a contaminação ocorre no alimento durante o processo de produção; as bactérias se multiplicam no alimento, de forma que um número, inicialmente inofensivo, pode alcançar níveis perigosos (Johns, 1995).

$\mathrm{O}$ único procedimento seguro para matá-las é o tratamento térmico em tempo $\mathrm{e}$ temperatura adequados para as formas vegetativas e esporuladas. $\mathrm{O}$ controle de acidez, do $\mathrm{pH}$ alimento, a atividade de água, a presença de oxigênio e compostos químicos acrescentados ou originados do próprio alimento são condições que podem regular o crescimento bacteriano (Marriot, 1985; Johns, 1995). 
Um componente importante para o processamento dos alimentos é a limpeza geral. Nas partículas de sujeira podemos encontrar bactérias. Os principais tipos de sujeira associados que podem estar nos objetos, superfícies, equipamentos e no ambiente são os resíduos de alimentos, óleos e gorduras, lixo, embalagens, pó e areia, manchas e corrosão.

O processo de limpeza consiste em 5 etapas básicas (Martins \& Kuaye, 1996, Johns, 1995, Marriot, 1985):

1) preparo e pré-limpeza: etapas que facilitam ou propiciam que a etapa de lavagem seja feita de forma adequada. Exemplos: eliminação de resíduos soltos, desmanche das partes de equipamentos em contato direto com o alimento ou o demolho em agentes de pré-limpeza (digestão de proteínas);

2) limpeza: eliminação da sujeira, geralmente com o uso de água e um detergente. $\mathrm{O}$ detergente tem o objetivo fundamental de reduzir a tensão superficial da água, suspender ou emulsionar a gordura e a sujeira;

3) enxágüe: eliminação dos resíduos deixados pelo processo de limpeza;

4) sanificação: $O$ uso de água quente ou produtos químicos não eliminam as bactérias de forma imediata, exigindo o chamado tempo de contato. A sanificação tem como objetivo destruir as bactérias que sobrevivem ao processo de limpeza. Os desinfetantes químicos mais comumente usados são os compostos halogênicos (clorados e os iodóforos), os surfactantes catiônicos (quaternário de amônio), os surfactantes anfóteros (anfotensivos) e os derivados fenólicos.

5) secagem: necessária para a eliminação da água que atua como meio de transferência e crescimento bacteriano. É feita mediante evaporação ou uso de toalhas ou papel apropriados.

Uma efetiva higiene na unidade processadora de hortaliças requer os mesmos cuidados necessários ao processamento de alimentos de uma forma geral. Os vegetais estão expostos a muitas fontes de contaminação e podem estar expostos a adicionais 
contaminações durante o recebimento, armazenamento e ao longo do seu processamento (Marriott, 1985).

\subsection{Sanificantes químicos}

Entre os sanificantes mais utilizados, o cloro destaca-se devido ao seu baixo custo e facilidade de obtenção. Cloro é um termo genérico para denominar diferentes compostos sanificantes representados pelo cloro elementar, hipocloritos, cloraminas inorgânicas, cloraminas orgânicas e o dióxido de cloro (Marriott, 1985).

O cloro tem sido utilizado há mais de cem anos no tratamento da água de abastecimento público e na desinfecção em águas de piscina, com o propósito fundamental de destruir microrganismos patógenos, prevenindo enfermidades como febre tifóide, cólera, desinteria e hepatite (Pinto \& Rohring, 2003).

$\mathrm{Na}$ indústria de alimentos os derivados clorados têm sido utilizados principalmente na desinfecção da água de resfriamento, superfície de alimentos, tubulações, equipamentos, ambientes, pisos e paredes, com o objetivo tanto de eliminar microrganismos patogênicos quanto o de reduzir a população dos deteriorantes a níveis considerados seguros (Macedo \& Barra, 2002; ABERC, 2001).

O hipoclorito de sódio e o hipoclorito de cálcio são os dois sanificantes mais frequientemente usados em indústrias processadoras de frutas e vegetais, embora os compostos de cloro orgânicos sejam considerados mais apropriados para desinfetar equipamentos destinados à manipulação de alimentos (Marriott, 1985).

Embora o cloro elementar seja mais barato em termos de cloro disponível, os hipocloritos de sódio e de cálcio são mais facilmente aplicáveis em baixas concentrações de rápida ação e menor custo do que outros halogênios. No entanto, são sensíveis às mudanças de temperatura e $\mathrm{pH}$, material orgânico e tendem a ser mais corrosivos e irritantes da pele (Marriott , 1985).

Quando o cloro é adicionado à água, uma pequena quantidade, normalmente 0,25-0,75 $\mathrm{mg} \mathrm{L}^{-1}$, reage com impurezas da água. A quantidade exigida depende da quantidade e qualidade das impurezas, o $\mathrm{pH}$, o tempo de contato, temperatura e a 
quantidade de cloro aplicado. A diferença entre a quantidade de cloro aplicado (dosagem de cloro) e a quantidade de cloro residual é conhecida como demanda de cloro da água. Suprida a demanda de cloro, temos o cloro disponível, que é o desinfetante ativo (Marriott , 1985 , Leitão, 1975).

$\mathrm{O}$ cloro residual ocorre em solução aquosa sob duas formas: cloro residual livre e o cloro residual combinado. O primeiro, dependendo do $\mathrm{pH}$, pode assumir três formas: cloro molecular $\left(\mathrm{Cl}_{2}\right)$, presente na faixa de $\mathrm{pH}$ igual ou inferior a 2; ácido hipocloroso, que predomina entre os valores de $\mathrm{pH} 4,0$ e 7,5; íon hipoclorito, que predomina na faixa de pH entre 7,5 e 9,5 (Nascimento et. al., 2003; Martins \& Kuaye, 1996). O segundo, cloro residual combinado, pode assumir a forma de monocloramina $\left(\mathrm{NH}_{2} \mathrm{Cl}\right)$, dicloramina $\left(\mathrm{NHCl}_{2}\right)$ ou tricloramina $\left(\mathrm{NCl}_{3}\right)$ que são agentes oxidantes bactericidas menos ativos e vagarosos que o cloro livre. $\mathrm{O}$ cloro residual combinado é formado, quando o processo de cloração é efetuado na presença natural ou acrescido de amônia (tratamento da água de abastecimento). O cloro residual combinado em $\mathrm{pH}$ 9,0 está presente, principalmente, como monocloraminas, ao redor do $\mathrm{pH} 7,0$ são formadas as dicloraminas e entre esses 2 valores de $\mathrm{pH}$ existe a mistura de ambas (Richter \& Netto, 1995).

O cloro livre é a medida do poder oxidante ou biocida do cloro ativo em termos de cloro elementar $\left(\mathrm{Cl}_{2}\right)$, expresso em porcentagem por peso (Pinto \& Rohring, 2003).

O cloro elementar dissolve-se ligeiramente na água, formando o ácido hipocloroso $(\mathrm{HClO})$ e o ácido clorídrico $(\mathrm{HCl})$. O ácido hipocloroso é um ácido fraco que se dissocia parcialmente em $\mathrm{H}^{+}+\mathrm{ClO}^{-}$. O ácido hipocloroso é o principal desinfetante da água, e o íon hipoclorito ( $\mathrm{ClO}^{-}$), um agente oxidante forte. $\mathrm{O}$ hipoclorito se reduz ao ânion cloreto ( $\mathrm{Cl}^{-}$), que é inativo, quando cumpre seu papel oxidante. A ação bactericida do cloro molecular ou do ácido hipocloroso é muito superior ao íon hipoclorito, devido a sua não-dissociação. Assim, o pH da solução influencia na efetividade do cloro como um agente germicida. $\mathrm{O}$ cloro é mais eficiente em pH 7,4 a 7,6, do que em valores altos de $\mathrm{pH}$, quando o cloro está na sua maioria como hipoclorito (Pinto \& Rohring, 2003; Macedo 2002) . 
Macedo (2002) refere pesquisas que mostram que em $\mathrm{pH} 8,0,35 \%$ do cloro livre está como ácido hipocloroso, concentração considerada capaz de obter redução significativa dos microrganismos na água e que em pH acima de 8,5 , a concentração de HClO em solução é tão pequena que já não haveria uma ação sanificante eficiente.

O aumento da temperatura das soluções interfere na solubilidade do cloro, e a alta concentração e/ou menor $\mathrm{pH}$ podem levar à corrosão de metais, não podendo o tempo de contato ultrapassar 20 a 30 minutos (Marriott , 1985).

$\mathrm{Na}$ década de 70 , surgem os chamados derivados clorados orgânicos, denominados cloraminas orgânicas, destacando-se o dicloroisocianurato de sódio e o ácido tricloroisocianúrico. As cloraminas orgânicas são produtos de reação do ácido hipocloroso com aminas, iminas, amidas e imidas e possuem uma estabilidade maior no armazenamento do que os compostos clorados inorgânicos. Os derivados clorados inorgânicos possuem validade de 4 meses, enquanto os de origem orgânica de 3 a 5 anos. São mais estáveis em solução aquosa, o que implica numa liberação mais lenta do ácido hipocloroso, permanecendo efetivas por períodos de tempo maiores na presença de matéria orgânica (Macedo \& Barra, 2002).

Uma característica considerada vantajosa para o uso do dicloroisocianurato de sódio é o pH de sua solução a $1 \%$ que varia de 6,0 a 8,0 , enquanto o pH de outros derivados clorados, como o hipoclorito de sódio e/ou de cálcio, varia de 11,0 a 12,5, intervalo em que já é cáustico (Macedo \& Barra, 2002).

Adams et al. (1989) observaram que uma inclusão de $100 \mathrm{mg} \mathrm{L}^{-1}(\mathrm{pH} 9,0)$ de cloro disponível reduziu a contagem bacteriana em $97,8 \%$. $\mathrm{O}$ ajuste do $\mathrm{pH}$ das soluções de hipoclorito de 9,0 para 4,5-5,0 com ácidos orgânicos e inorgânicos produziram aumento de 1,5-4,4 vezes no efeito microbicida.

Bloomfield \& Miles (1979) verificaram que a acidificação do pH 9,5 para 6,0 aumentou em 20 vezes o teor do ácido hipocloroso, o que representou um aumento de 1,3 vezes na sua atividade biocida. Relataram que as diferenças de atividade entre as formulações do dicloroisocianurato (geralmente maior para o dicloro) e o hipoclorito de sódio não são inteiramente devidas ao efeito do $\mathrm{pH}$ e sim às diferenças fundamentais existentes entre as propriedades e modo de ação dos 2 sistemas. Relataram que a maior 
atividade do dicloro, comparado com o hipoclorito, pode ser o resultado de ação antibacteriana adicional exercida pelo isocianurato e clorocianurato presentes no sistema e, provavelmente, pelo fato de que para o dicloro apenas $50 \%$ do total de cloro está presente como cloro livre, comparado com $100 \%$ para o hipoclorito de sódio, o que afeta a química da reação bactericida.

Sant'Ana et al. (2002) referem que as concentrações mais indicadas para as soluções cloradas se situam na faixa de 50 a $100 \mathrm{ppm}$. Afirmam que vários fatores contribuem para a perda de efetividade do cloro e que a estocagem inadequada é um deles. Outro aspecto a ser considerado é a natureza hidrofóbica dos vegetais que protege os microrganismos da exposição ao cloro e outros produtos sanificantes que não penetram ou dissolvem as ceras protetoras. Deve-se implementar a monitoração do teor de cloro residual, através de kits colorimétricos e do $\mathrm{pH}$ da solução, para que se tenha controle rápido na eficiência da sanificação. Caso haja algum desvio dos parâmetros adotados, deve-se tomar como ações corretivas um reforço na cloração, ajuste do $\mathrm{pH}$ ou a troca sistemática da água de lavagem

Apenas soluções recentemente preparadas devem ser utilizadas, já que o armazenamento dessas soluções podem resultar em um declínio do poder e atividade do sanificante (Marriott, 1985).

O dióxido de cloro é outro composto clorado e conhecido por ter 2,5 vezes mais o poder de oxidação do cloro. Esse composto não é tão efetivo como o cloro a pH 6,5, mas sim a pH 8,5. Essas características sugerem que o $\mathrm{ClO}_{2}$ é menos afetado pelas condições de alcalinidade e matéria orgânica. Não é hidrolisado em solução aquosa e, sendo assim, a molécula intacta parece ser o princípio ativo (Marriott , 1985)

No grupo dos sanificantes halogênicos ainda existem os compostos iodóforos de rápida ação na faixa de $\mathrm{pH}$ ácido e em água fria e dura. Produtos que contenham iodo ou seus compostos aumentaram de popularidade em anos passados devido às propriedades não corrosivas, não irritantes e não tóxicas quando aplicados nas concentrações recomendadas. Outra razão para o aumento do uso dos iodóforos é que esses sanificantes deixam uma cor residual, a qual indica as áreas de aplicação. Iodóforos também possuem capacidade de umidificação, penetração e detergência, sem 
passar sabor e odor desagradáveis. São constituídos de surfactantes não iônicos mais o iodo. Destroem um amplo espectro de bactérias, vírus fungos e atuam rapidamente, como o cloro (Marriott, 1985).

Os compostos de cloro, principalmente a água sanitária, são alcalinos e os iodóforos são moderadamente ácidos. Em conseqüência, estes últimos são mais suaves e menos tóxicos, no entanto são mais caros. Os iodóforos são inativados por resíduos orgânicos e por alguns plásticos, tingem os alimentos que entram em contato e, quando não enxaguados, podem deixar uma coloração amarronzada (Johns, 1995).

$\mathrm{O}$ ozônio é outro sanificante químico que se presta ainda à desinfecção de vegetais, sem deixar resíduos, como na utilização de hipoclorito de sódio. A ozonização da água de lavagem apresenta duas vantagens: a reação com a matéria orgânica não produz compostos tóxicos como os compostos clorados e a adição de ozônio em solução é estável por curto período de tempo, revertendo-se a oxigênio. Estima-se que a meia vida do ozônio é de aproximadamente 20 minutos (Torres et al., 1996).

Os testes recomendados pela Food and Drug Administration (FDA), segundo Marriott (1985), para a verificação e monitoramento de cloro ativo em soluções sanificantes são:

\section{1) Médodo iodométrico :}

Teste de titulação em que o cloro toma o lugar do iodo do iodeto de potássio em uma solução ácida e forma cor azul com o amido. A descoloração ocorre pela adição de um tiossulfato padronizado. Esse teste é geralmente utilizado para medir altas concentrações residuais.

2) Ortotolidina colorimétrica de comparação :

Teste no qual uma solução incolor de ortotolidina é acrescentada a uma solução de cloro. Uma substância de coloração laranja-amarronzada proporcional a essa concentração é produzida, a qual é comparada a uma cor padrão.

3) Teste da Fita Indicadora:

Teste rápido de limitada precisão, na qual fitas testes usualmente impregnadas com amido iodo são imersas. A cor desenvolvida é comparada com um padrão. 


\subsection{Sanificação química e eficiência microbicida}

Uma substância química para ser reconhecida como um sanificante necessita passar pelo teste de eficiência sanificante - Teste de Chambers, que consiste em eliminar $99,999 \%$ de uma população 75 a 125.000 .000 células de Escherichia coli e Staphylococcus aureus no intervalo de 30 segundos após a aplicação a $20^{\circ} \mathrm{C}$ (Marriott, 1985).

A atividade do cloro como um agente antimicrobiano não foi completamente determinada. No passado, foi sugerido que o ácido hipocloroso, o mais ativo dos compostos, destrói as células microbianas por oxidação dos grupos sulfidrilas de certas enzimas importantes do metabolismo dos carboidratos. As aldolases foram consideradas os principais sítios de ação devido à natureza essencial destas no metabolismo (Marriott, 1985).

Outros modos de ação têm sido propostos como a interrupção da síntese protéica; descarboxilação oxidativa dos aminoácidos a nitrilas e aldeídos; reação com ácidos nucléicos, purinas e pirimidinas; desequilíbrio metabólico após a destruição de enzimas importantes; induzem à lesões no ácido desoxirribonucléico (DNA), inibição do fornecimento de oxigênio e da fosforilação oxidativa, acoplado como vazamento de algumas macromoléculas; formação do N-cloro tóxico derivado da citosina; surgimento de aberrações cromossomiais (Marriott, 1985).

Segundo Marriott (1985), as células vegetativas absorvem cloro livre , mas não o combinado. Cloraminas formadas no protoplasma das células não causam destruição inicial. Experiências com uso do $\mathrm{P}_{32}$ na presença do cloro sugeriram que há uma mudança de permeabilidade destrutiva na membrana celular microbiana. Ainda, refere estudos nos quais o cloro afetaria a função da membrana celular, especialmente o transporte de nutrientes extracelulares e que aminoácidos e carboidratos marcados não puderam ser absorvidos por células tratadas com cloro. Além disso, afirma que uso de aminoácidos marcados com $\mathrm{C}_{14}$ revelaram que o dióxido de cloro interrompia a síntese protéica em Escherichia coli, embora não determinado a que grau. 
Compostos liberadores de cloro são reconhecidos por estimular a germinação de esporos e a subseqüente inativação dos esporos germinados. Além disso, foi demonstrado que o cloro altera a permeabilidade do esporo através de mudanças tegumentares, com a subseqüente liberação do $\mathrm{Ca}^{+2}$, ácido dipicolínico (DPA), RNA e DNA (Marriott, 1985).

Mokgatla et al.(2002), em revisão bibliográfica, citam que nenhum microrganismo conhecido possui um mecanismo enzimático específico para a inativação do ácido hipocloroso (HOCl). Assim, embora o ácido hipocloroso seja um ácido não seletivo e oxidante altamente reativo, o qual age sobre uma enorme gama de compostos intra-celulares, seus mecanismos de ação não são completamente conhecidos. Relatam ainda que o ácido hipocloroso influencia a permeabilidade e atividade da membrana, ex. gliceraldeído-6-fosfato dehidrogenase e lactato (LDA) e glicerol-6-fosfato dehidrogenases, inativa enzimas, primariamente atingindo os grupos ferro-enxofre, e interferindo na síntese de DNA.

Tem sido demonstrado que a cloramina, formada da reação do ácido hipocloroso com amônia, induz a lesões no DNA e causa quebra na cadeia simples do DNA. O ácido hipocloroso pode gerar uma radical hidroxila altamente reativo ( $\mathrm{OH})$, quando reage com superóxidos ( $\mathrm{HOCL}+\mathrm{O}_{2}{ }^{-} \rightarrow \cdot \mathrm{OH}+\mathrm{Cl}^{-+} \mathrm{O}_{2}$ ). A maior fonte de superóxido $\left(\mathrm{O}_{2}{ }^{-}\right)$na bactéria é a autoxidação dos componentes da cadeia respiratória de transporte de elétrons, quando três divisões são criadas para cada 10.000 elétrons transferidos. Além disso, o ácido hipocloroso reage com o peróxido para formar oxigênio elementar $\left(\mathrm{OHCl}^{-}+\mathrm{H}_{2} \mathrm{O}_{2} \rightarrow\left({ }^{1} \mathrm{O}_{2}{ }^{*}-\mathrm{H}_{2} \mathrm{O}+\mathrm{Cl}^{-}\right)\right.$, demonstrando ser altamente reativo, danificando o DNA (Mokgatla et al., 2002),

O hipoclorito de cálcio e o hipoclorito de sódio são efetivos na desativação de células microbianas em suspensões aquosas e requerem tempo de contato de aproximadamente 1,5 -100 segundos. Uma redução na população celular para a maioria dos microrganismos pode ser alcançada em menos de $10 \mathrm{seg}$, com teores relativamente baixos de cloro livre disponível (FAC) (Marriott, 1985).

Os esporos bacterianos são mais resistentes ao hipoclorito do que as células vegetativas, e o tempo requerido para uma redução de $90 \%$ em uma população de 
células pode levar, aproximadamente, $7 \mathrm{seg}$ a $20 \mathrm{~min}$ ou mais. A concentração de cloro livre disponível necessária para a inativação de esporos bacterianos é aproximadamente 10-100 vezes maior: 1000 comparados a aproximadamente $6-13 \mathrm{mg} \mathrm{L}^{-1}$ para as células vegetativas. Assim, a aplicação de sanificantes em que a concentração de ácido hipocloroso e tempo de contato são menores, há limitado efeito sobre esporos bacterianos (Marriott, 1985).

Os sanificantes clorados são efetivos contra bactérias Gram-negativas e Gram-positivas e, condicionalmente, contra certos vírus e esporos. Tendem a uma baixa capacidade de penetração, por isso, microrganismos encontrados em sujidades minerais e entre fendas e rachaduras podem não ser destruídos. A formação de biofilmes pode também proteger microrganismos da ação sanificante (Marriott, 1985).

O cloro disponível originado dos hipocloritos e outras substâncias químicas liberadoras de cloro, como o dicloroisocianurato de sódio, reage e é inativado pela matéria orgânica residual. Assim, é recomendável que a quantidade e concentração de cloro em solução sejam suficientes para sua função sanificante (Marriott, 1985).

Cloraminas inorgânicas são compostos formados de reações do cloro com nitrogênio de amônia, enquanto as cloraminas orgânicas são formadas através de reações do ácido hipocloroso com aminas, amidas, iminas ou imidas. Células vegetativas e esporos bacterianos são mais resistentes às cloraminas do que aos hipocloritos. Outras cloraminas combinadas são igualmente ou mais efetivas do que os hipocloritos na inativação de microrganismos. O dicloroisocianurato de sódio é mais ativo do que o hipoclorito de sódio contra a $E$. coli, S. aureus e outras bactérias (Marriott, 1985).

Compostos clorados são usados em solução de imersão ou aplicados sobre superfícies onde o cloro livre pode reagir com as células. As células vegetativas são destruídas mais facilmente do que os esporos de Clostridium, os quais são destruídos mais facilmente do que os esporos de Bacillus (Marriott, 1985).

O hipoclorito de sódio é considerado efetivo na eliminação de alguns microrganismos patogênicos presentes nas superfícies dos vegetais. Contudo, a eliminação de patógenos presentes nas superfícies dos vegetais pelo uso do cloro é 
limitada e muitas vezes imprevisível. Considerando que o $\mathrm{pH}$ da água possui impacto tão significativo sobre a atividade do cloro, torna-se muito importante seu ajuste na solução sanificante (Oliveira \& Valle, 2000).

Mokgatla et al. (2002), em estudo a respeito do isolamento de Salmonella em abatedouros de frangos, que adquiriu tolerância ao ácido hipocloroso, revela que a população de Salmonella, após uma lavagem de carcaças de frango com cloro foi tão alta quanto a da etapa antes da lavagem, indicando a presença de cepas resistentes ao HOCl. Essas cepas resistentes crescem na presença de $28 \mathrm{mg} \mathrm{L}^{-1}$ de $\mathrm{HOCl}$. Nenhuma informação é disponivel sobre o mecanismo de resistência ao hipoclorito e nenhuma regulação do hipoclorito tem sido identificadas. Além disso, a resistência das cepas não expõe o mesmo grau de dano ao DNA como as cepas sensíveis. Assim, destacam que a ocorrência de Salmonella, capaz de crescer na presença de $28 \mathrm{mg} \mathrm{L}^{-1}$ de ácido hpiocloroso, é de relevância para as industrias de processamento de alimentos e de tratamento de água para consumo, contanto que essas cepas sobrevivam a regimes de sanificação.

Importante destacar o trabalho de Baruffaldi et al.(1984) que avaliou a contaminação de parasitária presentes em 6 diferentes tipos de hortaliças, através de exames bacteriológicos e parasitológicos e o efeito do tratamento químico sobre parasitas identificados em folhas de alface. Verificou a presença de coliformes fecais em $75 \%$ das amostras, com contagens de 10 a $10^{6}$, e de $E$. coli em $64 \%$, com contagens de 10 a $10^{3}$, e abundante e freqüente presença de protozoários ciliados, amebas e nematóides de vida livre, indicadores da possível coexistência de protozoários do gênero Entamoeba e de helmintos que podem representar risco a saúde. Verificou que o efeito conjugado da lavagem e desinfecção com solução de hipoclorito de sódio a $40 \mathrm{mg} / \mathrm{L}$ de cloro livre por 10 minutos, altamente eficiente do posto de vista parasitológico, confirmando estudos revisados pelo autor na desinfecção de hortaliças com hipoclorito de sódio visando minimizar os riscos da presença de bactérias e parasitas patogênicos ao homem. 


\subsection{Sanificação química e higiene dos alimentos}

Os alimentos para consumo humano necessitam ser tratados de alguma maneira, mediante cocção, lavagem, etc. para que não se tornem, durante o processo de produção, veículos de enfermidade, principalmente, por três formas: 1) um contaminante (toxinas, bactéria, vírus ou parasita) presente no alimento original não cozido, nem lavado, sobrevive ao processo de produção; 2) a contaminação (física, química ou biológica) é acrescida ao alimento durante o processo de produção; 3) as bactérias se multiplicam no alimento de forma que um número inicialmente inofensivo alcança patamares de risco (Sant'Ana et al., 2002).

A contaminação não surge de forma espontânea, as bactérias patogênicas chegam ao processo de produção de alimentos através das carnes e verduras cruas e também pelas mãos dos empregados. Os vetores introduzem contaminantes no processo de produção de álimentos. Assim, vetores são materiais, objetos ou seres vivos que são portadores de contaminação física, química ou biológica até o final do sistema de produção de alimentos. A produção de alimentos pode realizar-se totalmente em um só local (restaurante e cozinha juntos) ou pode efetuar-se em vários lugares, incluindo transporte entre os mesmos. O objetivo da higiene dos alimentos é o controle da contaminação no sistema de produção/serviço de alimentos (Johns, 1995).

A desinfecção é necessária para destruir as bactérias que sobrevivem ao processo de limpeza. A desinfecção se efetua mediante o aquecimento ou usando produtos químicos, como água sanitária. Os desinfetantes químicos não matam as bactérias de forma imediata, necessitam de tempo para atuar, o chamado tempo de contato. Os desinfetantes podem ser inativados por restos de alimentos, pelos tecidos dos panos de limpeza e por matérias de algumas superfícies. A água sanitária ataca tecidos, alguns plásticos e artigos de metal (Sant'Ana et al., 2002).

Há possibilidade de recontaminação do produto durante a etapa de embalagem, especialmente se esta for realizada manualmente. Sant'Ana et al.(2002) apresentam estudo mostrando o grau de contaminação das luvas de manipulação na etapa de seleção após a sanificação e a recontaminação do alimento, provavelmente em virtude do 
número de manipuladores e da ausência de sanificação das luvas. A medida de controle sugerida para prevenir este perigo seria o treinamento do pessoal envolvido, no aspecto de higiene pessoal.

Um importante passo no processamento mínimo de vegetais é a lavagem, freqüentemente acompanhada de imersão em solução antimicrobiana para reduzir a carga microbiana. A lavagem de alface em água contendo cloro livre na concentração de $100 \mathrm{mg} \mathrm{L}^{-1}$ reduz a população bacteriana mais de 100 vezes. O cloro leva à inativação de células vegetativas na água e sobre os equipamentos durante processamento, como parte do sistema análise de perigos e pontos críticos de controle (APPCC) evitando assim, o desenvolvimento de bactérias e a contaminação cruzada (Francis et al., 1999)

Nguyen-The \& Prunier (1989) afirmam que a estrita higiene durante a lavagem e desinfecção é fundamental para evitar a contaminação do produto. Na água clorada de banhos de lavagem na linha de processamento de saladas de chicória foram encontradas $10^{3}$ bactérias $\mathrm{ml}^{-1}$. O produto lavado em tais banhos, devido à reutilização da água de lavagem, pode resultar em transferência de microrganismo e possibilidade de contaminação.

\subsection{Sanificação química na linha de processamento de hortaliças}

A sanificação é um dos métodos de conservação aplicados aos alimentos processados, diminuindo a quantidade de microrganismos contaminantes presentes e aumentando a vida útil (Ferreira et al., 2003).

A CVS/SES-SP (São Paulo,1999) estabelece os produtos e as concentrações recomendadas para a desinfecção de alimentos : hipoclorito de sódio a 2,0-2,0\%, hipoclorito de sódio a $1 \%$ e cloro orgânico, em concentrações de 100 a 250 ppm $\left(\mathrm{mg} \mathrm{L}^{-1}\right)$

Pesquisa parasitológica desenvolvida em um restaurante universitário observou que $92,5 \%$ de 40 amostras de alface coletadas estavam contaminadas por ovos de oocistos e enteroparasitas e que uma reestruturação da rotina de tratamento de verduras foi conseguida através da apresentação de resultados à direção do R.U. e seus 
funcionários, fazendo com que em uma segunda etapa da pesquisa, $100 \%$ das amostras avaliadas das verduras consumidas não apresentassem contaminação. $O$ trabalho, levado a cabo no período de novembro de 1995 a janeiro de 1999, conseguiu provar que o tratamento das verduras, com a utilização de sanificantes, foi possivel eliminar por completo a contaminação por enteroparasitas (Lagaggio et al., 2002).

Sant'Ana et al. (2002), em pesquisa desenvolvida com produtos minimamente processados, avaliaram que $33,3 \%$ de um total de 42 amostras estavam em desacordo com as especificações da resolução da ANVISA n ${ }^{\circ} 12$ em relação aos coliformes a $45^{\circ} \mathrm{C}$, confirmando dados de revisão nos quais os vegetais minimamente processados apresentavam condições higiênico-sanitárias insatisfatórias, ligadas às etapas de obtenção da matéria prima, processamento e distribuição.

Os alimentos minimamente processados constituem um excelente meio de crescimento de microrganismos, devido à presença de tecidos lesados e do alto teor de umidade, que aumenta durante o seu armazenamento, elevando o seu potencial de deterioração. Assim, a sanificação é considerada, do ponto de vista da segurança alimentar, como etapa crítica de controle do processo e falhas no tempo de contato, bem como na concentração do agente sanificante, podem originar perigos biológicos (Ferreira et al., 2003; Sant'Ana et al., 2002). O cloro é grandemente utilizado na sanificação de vegetais e frutas minimamente processados, embora sua efetividade seja limitada a alguns produtos (Hurst, 1995).

Nascimento et al. (2002) avaliaram a eficiência da sanificação em 10 diferentes tipos de hortaliças (alface, acelga, cheiro-verde, repolho, pepino, pimentão, cenoura, cebola, tomate e vagem) coletados em restaurantes self-service de São Luiz, MA, sobre coliformes fecais. Os vegetais foram submetidos a 6 diferentes tipos de tratamento sanificante: soluções com 2 tipos de vinagre , o "ácido" e o de álcool, em soluções com $2,5 \mathrm{~mL}^{-1}$, por um período de 90 minutos; duas soluções com $1 \mathrm{~mL}$ de água sanitária, por período de 10 e 90 minutos. Concluíram que dos tratamentos de sanificação efetuados, a maior eficiência foi da solução de hipoclorito de sódio por 10 minutos, com eliminação total dos coliformes fecais, de um total inicial que variou de $10^{2}$ a $10^{4}$ 
$\mathrm{NMP} / \mathrm{g}$. Constataram que para os demais tratamentos o tempo deveria ser superior a 10 minutos.

\subsection{Compostos sanificantes clorados e a segurança alimentar}

A manutenção da integridade, capacidade e higidez dependem da ingestão diária de alimentos quantitativa e qualitativamente saudáveis e que não coloquem em risco a saúde do consumidor.

O hipoclorito de sódio, o mais usados dos sanificantes para assegurar a qualidade e a segurança microbiológica dos alimentos, apresenta uma grande desvantagem, por deixar sabor residual no alimento e poder reagir com o material orgânico e formar, potencialmente, produtos tóxicos (Ferreira et al., 2003, Oliveira \& Valle, 2000, Sapers \& Simmons, 1998).

Há discussões sobre a restrição do uso do cloro na água de processamento de alimentos. Estudos têm embasado a formação e persistência de compostos tóxicos chamados de trihalometanos (THM's) (ex. clorofórmio) e sua demonstrada carcinogenicidade. A não possibilidade do uso do cloro na indústria tão dependente deste traria um maior impacto sem que uma alternativa viável pudesse ser encontrada (Hurst, 1995; Sapers \& Simmons, 1998).

A importância dos THM's em âmbito mundial prende-se ao fato de que , além de serem considerados potencialmente carcinogênicos, são também indicadores da possível presença de compostos organoclorados (ácido acético clorado, haloacetonitrilos, clorofenóis, etc) também resultantes do processo de cloração e ainda mais perigosos que os próprios THM's (Macedo \& Barra, 2002).

Em 1974, nos Estados Unidos, estudos demonstraram pela primeira vez a correlação positiva entre água de abastecimento público, que sofreu processo de desinfecção com derivados clorados, e câncer. A partir de 1982, através de pesquisa epidemiológica, foi evidenciada uma correlação positiva entre os organoclorados em água potável e a carcinogênese, aumentando o risco com o número de anos de exposição (Macedo \& Barra, 2002). 
$\mathrm{O}$ aspecto importante que contribui para o aumento do uso de derivados clorados de origem orgânica é sua característica de não formar trihalometanos (THM), em níveis considerados significativos, como subprodutos do processo de desinfecção (Macedo \& Barra, 2002).

Prata (2000) afirma que oferecer segurança é matéria extremamente complexa, envolvendo os setores produtivos, transformadores, de comercialização, os próprios consumidores e os poderes públicos, esses últimos na forma de exigência, diretrizes, normas, limites padrões, exercendo tarefas inalienáveis de inspeção, controles, fiscalização e vigilância.

Numa economia de escala e em um mercado competitivo, todo e qualquer custo necessita ser eficientemente controlado, objetivamente contemplando custos/riscos e ou benefícios.

Exige da comunidade científica, das instituições e dos profissionais envolvidos a releitura de todo o conhecimento científico e tecnológico que possibilite a escolha e a adoção de práticas de inspeção e controle efetivamente baseadas em evidências cientificas, para que possam oferecer as garantias necessárias de um alimento "íntegro e seguro", atendendo às expectativas dos consumidores, a realidade e os custos de produção (Prata, 2000). 


\section{MATERIAL E MÉTODOS}

\subsection{Descrição do local}

O estudo de caso foi realizado no Restaurante Universitário da Escola Superior de Agricultura "Luiz de Queiroz" (ESALQ/USP), na cidade de Piracicaba/SP. Esta unidade de alimentação e nutrição (UAN) produz por volta de 1500 refeições dia entre almoço e jantar. A quantidade total de hortaliças processadas varia em função do tipo e combinações vegetais do cardápio que oferece 4 saladas diversas, das quais 3 cruas entre folhosas, frutos, raízes ou tubérculos, alcançando, diariamente, ao redor de $100 \mathrm{~kg}$ de hortaliças sanificáveis.

\subsection{Natureza das amostras}

As hortaliças são fornecidos à UAN por contrato com atacadistas de produtos adquiridos na Central de Abastecimento S/A (CEASA) da região e/ou produtores locais, além de fornecimentos eventuais vindo da Fazenda Areião/Esalq-USP.

As hortaliças foram escolhidas em função dos seguintes fatores: a alface, por ser o vegetal folhoso de maior aceitabilidade e, conseqüentemente, maior consumo; o repolho, além do seu custo acessível e resistência à estocagem, ter suas folhas menos expostas ao meio; o rabanete, por ser a porção subterrânea do vegetal consumido com casca; o tomate por crescer distante do solo, ter superfície lisa e, como o alface, ter demanda constante em UANs.

O fornecimento das hortaliças é feito diariamente no início da manhã, sendo retiradas imediatamente das caixas oriundas do mercado atacadista, para monoblocos de 
polietileno vazados específicos, seguindo diretamente para serem processadas ou armazenadas sob refrigeração ou à temperatura ambiente. A estocagem máxima se dá num prazo aproximado de 30 horas.

Os produtos adquiridos são os especificados como extra AA. o que corresponde aos de melhor qualidade dentro da classificação para vegetais, segundo o padrão da Companhia de Entrepostos e Armazenamento Gerais de São Paulo (CEAGESP).

As amostras foram coletadas no período de 7:30 a 10:30h, dentro do fluxo de produção de saladas a serem servidas no almoço.

\subsection{Fluxo de produção de saladas cruas}

O processamento das hortaliças destinadas a preparações servidas cruas segue etapas gerais e específicas, resumidas na Figura 1. Os manipuladores compõem grupo de 5 pessoas fixas no setor de processamento de hortaliças.

As hortaliças são retiradas do armazenamento refrigerado e/ou diretamente do fornecimento que chega à UAN diariamente, e são encaminhadas à área de processamento.

O primeiro procedimento é a lavagem em água corrente de abastecimento público. As folhas são soltas do pé, sendo descartadas as danificadas e envelhecidas; dos não folhosos são retiradas partes não comestíveis e danificadas. À medida que vão sendo lavadas, são acondicionadas em caixas de polietileno vazadas de uso específico na sanificação e enxágüe.

Após a lavagem as caixas de hortaliças são encaminhadas para a sanificação, feita mergulhando-as juntamente com as caixas em solução clorada previamente preparada, duas caixas por vez, num total aproximado de 12 a $48 \mathrm{~kg}$, dependendo dos vegetais processados. 
A alface passa por uma pré-lavagem de imersão, fora da área de processamento, antes de seguir para a lavagem.

O repolho é cortado longitudinalmente e transversalmente em 4 a 6 pedaços para facilitar a penetração da água entre suas camadas, também favorecida pela ação do manipulador.

O tomate e o rabanete são lavados um a um com o auxílio de um pano descartável (tipo Perfex) para auxiliar a remoção de sujidades.

Durante o processo de sanificação, as caixas são cobertas com placas de polietileno, conferindo peso necessário para que fiquem mergulhadas, permanecendo por período mínimo de 15 minutos, quando são retiradas e deixadas escorrer com o vegetal.

O enxágüe é feito em água corrente, com auxílio de uma mangueira, dentro da própria caixa de sanificação para a retirada do resíduo de cloro, auxiliado pela ação do manipulador.

Após o enxágüe, são retiradas das caixas de sanificação e transferidas para caixas com solução de vinagre agrin, e deixadas por 15 minutos, aproximadamente.

Após esse tratamento, as hortaliças são fracionadas, manual ou mecanicamente, e acondicionadas em cubas de inox do tipo gastronorm (cubas de dimensões padrão) próprias para balcão self-service refrigerado (previamente aspergidas com solução de álcool $70^{\circ} \mathrm{GL}$ ), e acondicionadas em passthru refrigerado (refrigerador para gastronorms com acesso duplo tanto pela cozinha quanto pelo refeitório) para serem consumidas, em geral, num período aproximado de 3 horas.

\subsection{Planejamento experimental}

O estudo foi realizado em duas etapas, a primeira com as amostras coletadas na UAN e processadas no Laboratório de Microbiologia de Alimentos, setor de lacticínios, da ESALQ / USP, no período de agosto a dezembro de 2003, e a segunda com 
amostras adquiridas no comércio local e processadas naquele laboratório durante o mês de junho de 2004 .

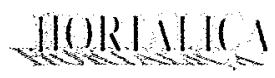

ARMAZENAMENTO

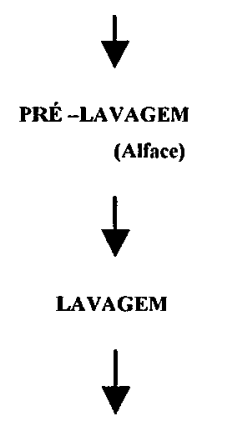

SOLUÇĀO CLORADA

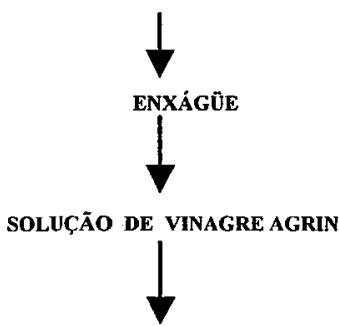

FFRACIONAMENTO

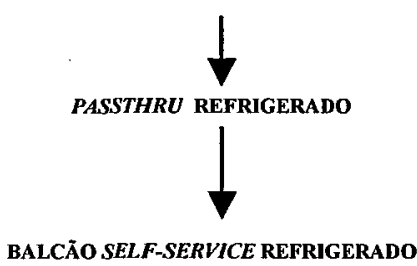

Figura 1 - Fluxograma geral de processamento para a obtenção de saladas cruas 


\subsubsection{Qualidade microbiológica inicial e eficiência do procedimento de lavagem e sanificação}

Em um primeiro momento, avaliou-se a eficiência do procedimento de lavagem em 4 tipos de hortaliças: a alface crespa, o repolho comum, o tomate e o rabanete. As amostras foram coletadas em dois pontos do fluxo processamento: 1hortaliça sem lavar, 2- hortaliça lavada. Foram realizadas 3 repetições em diferentes datas, à medida que as hortaliças foram sendo disponibilizadas no cardápio, perfazendo 24 amostras analisadas.

A qualidade sanitária inicial das amostras foi avaliada através da contagem do total de microrganismos aeróbios mesófilos, coliformes totais e E. coli, dentro de parâmetros indicativos, segundo a ANVISA (Brasil, 2001). A eficiência do procedimento de lavagem foi avaliada considerando-se a redução da população microbiana das amostras lavadas em relação às amostras sem lavar.

Em um segundo momento, avaliou-se a eficácia do procedimento de sanificação. $O$ vegetal escolhido foi a alface crespa, avaliada em 3 diferentes pontos do fluxo de processamento: alface lavada, alface clorada e alface enxaguada com solução de vinagre; em todos os 3 pontos de coleta foram retiradas 1 amostra da $1^{\text {a }}$ e 1 amostra da última caixa do lote processado. Foram realizadas 14 repetições, com as amostras coletadas em diferentes datas, perfazendo 71 amostras analisadas (13 não realizadas). A eficácia da sanificação foi avaliada considerando-se a redução da população dos aeróbios mesófilos, coliformes totais e $E$. coli conferida, por cada uma etapas de tratamento e pelo total dos tratamentos, em relação a amostra lavada

As análises microbiológicas foram realizadas segundo metodologia descrita por Silva et al (2002) . 


\subsubsection{Preparo das amostras para as análises microbiológicas}

Na primeira fase do estudo, foram retiradas unidades ou frações de unidades de cada uma das caixas do lote a ser processado: alface $\rightarrow 1,5$ de $30 \mathrm{Kg}$, aproximadamente; repolho $\rightarrow 2,0$ de $25 \mathrm{Kg}$, aproximadamente; tomate $\rightarrow 2,0$ de $48 \mathrm{~kg}$, aproximadamente; rabanete $\rightarrow 0,8$ de $15 \mathrm{~kg}$, aproximadamente.

$\mathrm{Na}$ segunda fase do estudo, foi coletado o correspondente a $1,0-1,2 \mathrm{Kg}$ de alface dos 3 diferentes pontos do processamento; uma amostra da primeira caixa e outra da última caixa do lote, somando 6,0 a 7,0 $\mathrm{kg}$ de um total aproximado de 25 a $30 \mathrm{Kg}$ do lote.

A coleta das amostras foi aleatória, procurando ser representativa do lote. A coleta foi feita em sacos plásticos para alimentos de primeiro uso e as amostras, imediatamente, acondicionadas em caixa de isopor com gelo. As determinações microbiológicas foram realizadas em até 6 horas após a coleta.

Os pontos de coleta dentro da planta de processamento de hortaliças cruas estão representados na Figura 2.

As análises microbiológicas da $1^{\mathrm{a}}$ fase iniciaram-se com a obtenção da $1^{\mathrm{a}}$ diluição seriada: alface e repolho por trituração; tomate e rabanete por lavagem superficial .

As hortaliças folhosas foram trituradas com uso de liquidificador doméstico em copo de alumínio autoclavado. Previamente, fatiou-se a hortaliça com uso de faca de inox e tábua de polietileno branca, sanificados com álcool $70^{\circ} \mathrm{GL}$ e secos próximos à chama do bico de Bussen. Após, o vegetal era revirado manualmente (com uso de luva estéril), pesada uma porção de $25 \mathrm{~g}$ e triturada com $225 \mathrm{~mL}$ de solução salina peptonada estéril, obtendo-se a $1^{\circ}$ diluição seriada.

As amostras processadas por lavagem superficial foram distribuídas em 3 porções dentro de sacos de alimento reforçado de $1^{\circ}$ uso. Cada porção foi pesada e acrescentada de água salina peptonada esterilizada, o correspondente em mililitro ao 
peso em gramas do vegetal. A lavagem foi efetuada agitando-se a embalagem fechada por 10 vezes, massageando cada unidade vegetal e removendo as sujidades para a solução, operação esta repetida por 5 vezes. Após a lavagem, as 3 soluções foram misturados, e cada $1 \mathrm{ml}$ correspondendo a uma grama do alimento, diluição $10^{\circ}$. Assim, acrescentando-se $1 \mathrm{~mL}$ desta solução $10^{0}$ a $9 \mathrm{~mL}$ de água salina peptonada estéril, obteve-se a diluição seriada $10^{-1}$.
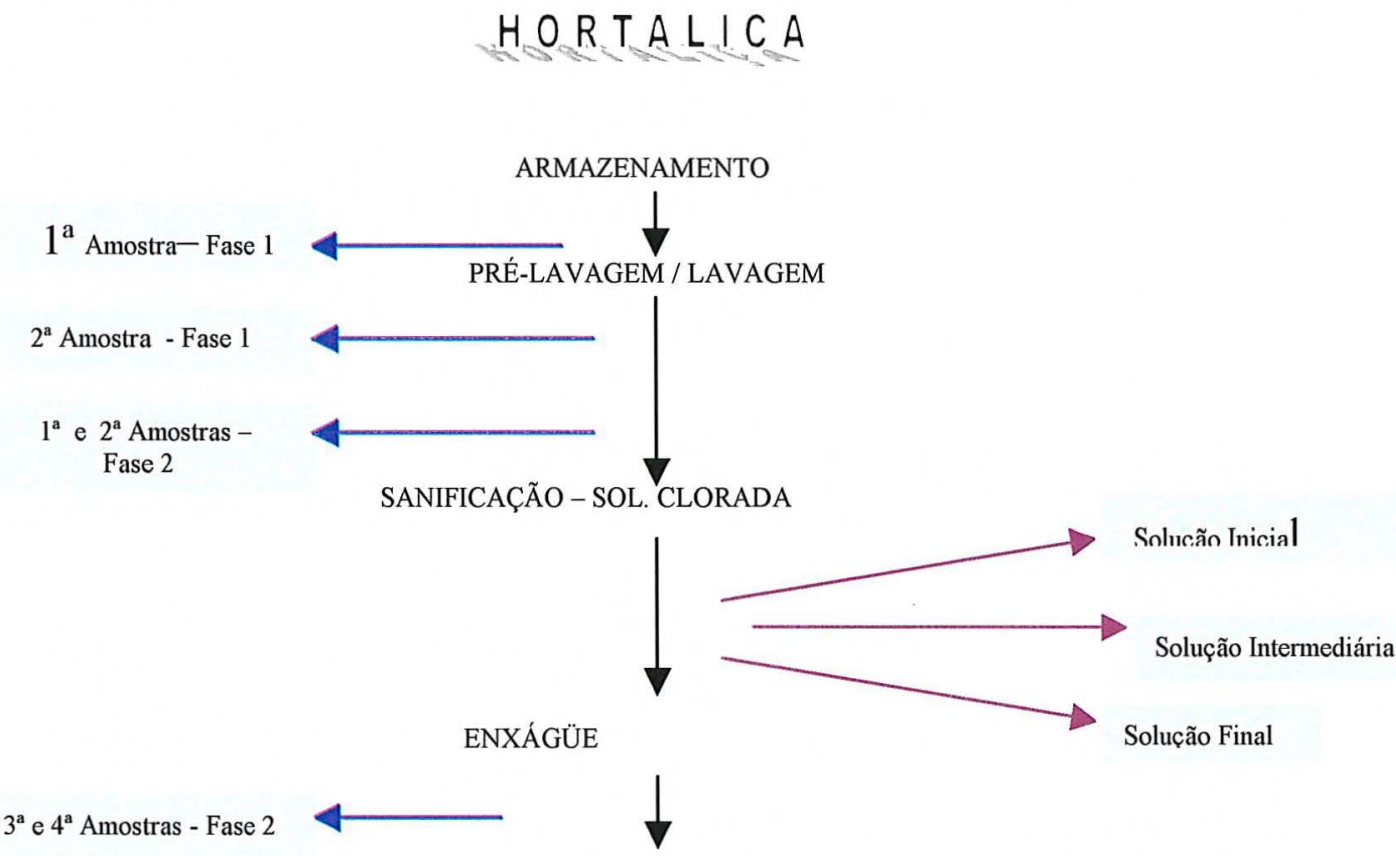

IMERSSÃO SOL. DE VINAGRE AGRIN

$5^{\mathrm{a}}$ e $6^{\mathrm{a}}$ Amostras - Fase 2

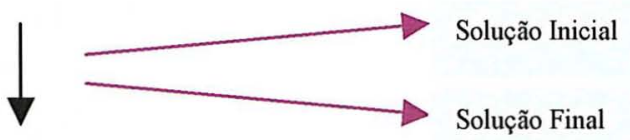

FRACIONAMENTO
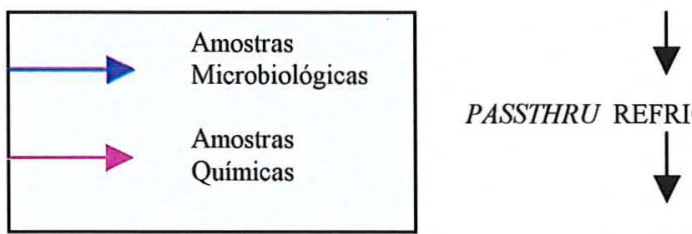

PASSTHRU REFRIGERADO

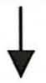

BALCÃO SELF-SERVICE REFRIGERADO

Figura 2 - Fluxograma da planta de processamento de saladas cruas com os pontos de coleta das amostras para as determinações microbiológicas e químicas 
As análises microbiológicas da $2^{\mathrm{a}}$ fase do estudo seguiram o roteiro das hortaliças folhosas da $1^{\mathrm{a}}$ etapa, exceto as amostras tratadas com cloro e vinagre agrin, respectivamente, trituradas com $223 \mathrm{~mL}$ de água salina peptonada estéril acrescida de 2 $\mathrm{mL}$ de solução de tiossulfato de sódio a $10 \%$ estéril e $225 \mathrm{~mL}$ de tampão fosfato $\mathrm{pH} 7$ estéril, com o objetivo de neutralizar, respectivamente, os resíduos de cloro e os resíduos ácidos.

\subsection{Determinação da contagem total de microrganismos aeróbios mesófilos}

Alíquotas de $1 \mathrm{~mL}$ foram semeadas em placas de Petri e inoculadas em meio ágar padrão para contagem (PCA) a $45^{\circ} \mathrm{C}$, em triplicata das diluições determinadas por ensaio inicial, seguindo a metodologia do plaqueamento em profundidade, e incubadas a $35^{\circ} \mathrm{C}$ por $24-48 \mathrm{~h}$.

A contagem foi determinada da placa cuja média ficou entre 25 a 250 unidades formadoras de colônia (UFC), multiplicada pelo inverso da diluição, obtendose assim o total de UFC/ $\mathrm{g}$ do alimento (Figura 3).

\subsection{Determinação da contagem de coliformes totais}

Alíquotas de $1 \mathrm{~mL}$ das diluições determinadas por ensaio inicial foram inoculadas, em uma série de três tubos por diluição, em caldo lauril sulfato triptose, complementado com 4-metil-umbeliferil-beta-D-glucoronídeo (LST-MUG) com tubos de Durhan invertidos e incubados a $35^{\circ} \mathrm{C}$ por $24-48 \mathrm{~h}$. Dos tubos com crescimento e produção de gás, foi repassada uma alçada do inóculo para tubos como Caldo Verde Brilhante (VB), com tubos de Durhan invertidos e incubados por 24-48 horas.

A contagem foi feita a partir dos tubos VB com crescimento e produção de gás (positivos) e determinada a partir da tabela do número mais provável (NMP) série de três tubos, considerando a frequiência de tubos positivos por diluição (Figura 3). 


\subsection{Determinação da contagem de E.coli}

Os tubos LST-MUG com crescimento em $24-48 \mathrm{~h}$, com ou sem produção de gás foram submetidos à luz ultravioleta $365 \mathrm{~nm}$ em uma cabine escura, e os que apresentaram fluorescência azul intensa, considerados positivos para a presença de $E$. coli.

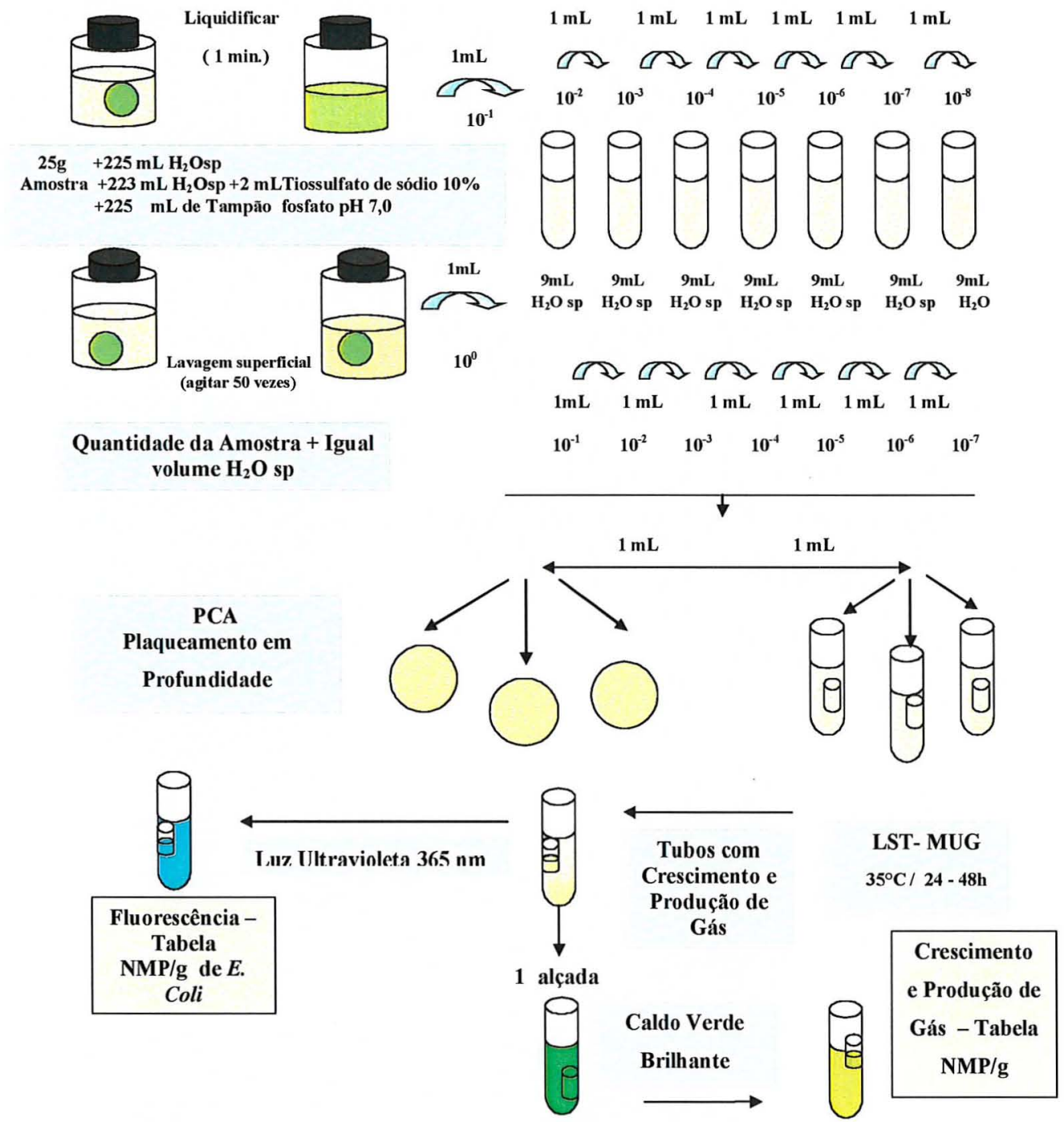

Figura 3 - Esquema de análise para contagem total de aeróbios mesófilos, coliformes totais e $E$. coli 
A contagem foi feita a partir dos tubos LST-MUG de três diluições consecutivas com o maior número de tubos positivos, e a determinação feita a partir da tabela de número mais provável (NMP) série de três tubos, considerando a frequiência de tubos positivos, por diluição ( Figura 3)

\subsubsection{Preparo das amostras para as determinações químicas}

\subsection{Solução clorada}

O sanificante adotado, o cloro orgânico, marca comercial cujo princípio ativo é o dicloisocianurato de sódio a $8,7 \%$ de cloro ativo. A solução é utilizada na concentração estimada de 100 a $200 \mathrm{mg} \mathrm{L}^{-1}$ de cloro livre.

A solução sanificante é feita a partir de $190 \mathrm{~g}$ do produto, previamente diluído no próprio copo medidor do produto, e acrescentado ao volume total de $125 \mathrm{~L}$ de água de abastecimento público filtrada. A completa dissolução do produto é feita com o auxílio de um remo, em caixa sanificação com capacidade de $400 \mathrm{~L}$, ambos de polietileno brancos e específicos para o procedimento.

A solução é reutilizada tantas vezes quanto permaneça o teor de cloro livre acima de $100 \mathrm{mg} \mathrm{L}^{-1}$, monitorado por fita dosadora de cloro livre .

As soluções foram coletadas em 3 momentos durante o período de 3 horas de processamento - amostra 1: logo após o preparo da solução, próximo das 7:30h; amostra 2: no período intermediário entre o início e o final do processo, próximo das 9:00h; amostra 3: ao final do período, próximo das 10:30h.

As amostras foram coletadas para frascos plásticos de $1^{\circ}$ uso e imediatamente acondicionadas em caixa de isopor com gelo, e realizadas as determinações químicas em até 4 horas após a coleta. 


\subsection{Determinação de cloro livre}

O cloro livre das amostras foi determinado por método iodométrico, através de titulação com o tiossulfato de sódio a $0,01 \mathrm{~N}$, utilizando a solução de amido indicadora, segundo metodologia descrita por Greenberg et al.(1985). O resultado foi calculado pela média das titulações feitas em triplicata e expresso em $m g \mathrm{de} \mathrm{Cl}_{2} \mathrm{~L}^{-1}$.

\subsection{Solução de vinagre agrin}

É preparada a partir de um volume aproximado de $15 \mathrm{~L}$ de água de abastecimento público filtrada em caixa de polietileno branca com capacidade de $30 \mathrm{~L}$. e aproximadamente meio frasco de $750 \mathrm{~mL}$ de vinagre agrin (fermentado acético de álcool a $90 \%$ e vinho tinto a $10 \%$, com $4 \%$ de acidez) marca comercial Saboroso®.

As soluções foram coletadas em 2 momentos - amostra 1: logo após o seu preparo; amostra 2 : após o $1^{\circ}$ ou $2^{\circ}$ uso. A solução de vinagre agrin é utilizada no máximo duas vezes, dependendo da não presença de sujidades visíveis em suspensão e acrescentado, de mais $100 \mathrm{~mL}$ de vinagre, aproximadamente.

As amostras foram coletadas para plásticos brancos de primeiro uso $\mathrm{e}$ acondicionadas imediatamente em caixa de isopor com gelo, e realizadas as determinações químicas em até 4 horas após a coleta.

\subsection{Determinação de pH}

As soluções foram analisadas em triplicata por meio de potenciômetro e o resultado médio expresso dentro da faixa de acidez de 1 a 14, conforme metodologia descrita Pregnolatto \& Pregnolatto (1985). 


\subsection{Determinação de acidez total e em ácido acético}

As soluções foram analisadas em triplicata por titulação com $\mathrm{NaOH} 0,1 \mathrm{~N}$, tendo a fenolftaleína a $1 \%$ como indicador, e o resultado médio expresso em $\% \mathrm{v} / \mathrm{v}$, segundo metodologia descrita pelo Pregnolatto \& Pregnolatto (1985).

\subsubsection{Dosagem de cloro livre pelo uso do kit colorimétrico}

O kit dosador de cloro livre por faixa colorimétrica compara a absorvância ou a transmitância de uma solução de concentração desconhecida, com o mesmo parâmetro de outra solução, qualitativamente idêntica à primeira, mas de concentração conhecida.

O teor cloro livre estimado por uso de fita dosadora de cloro livre em 4 faixas colorimétricas: $<50 ; 50$ a $100 ; 100$ a $200 ;>200$, marca comercial Ecolab $囚$ foi registrada em ficha de campo, imediatamente antes da coleta das soluções a serem tituladas.

As faixas de cloro livre indicadas pelo kit dosador foram confrontadas com os valores determinados por titulação. O kit dosador foi avaliado comparando-se a freqüência em que indicou o nível crítico de cloro livre abaixo de $100 \mathrm{mgL}^{-1}$.

\subsubsection{Estudo sobre o comportamento de soluções a base de dicloroisocianurato de sódio e hipoclorito de sódio na sanificação de hortaliças}

Soluções à base de dicloroisocianurato de sódio e hipoclorito de sódio em concentrações dosadas à $200 \mathrm{mg} \mathrm{L}^{-1}$ de cloro livre foram utilizadas no tratamento de alface inteira e fracionada, repolho inteiro e fracionado, tomate e rabanete e avaliadas em três repetições. 


\subsubsection{Preparo das amostras}

Foram preparadas soluções de 2,1 litros de cada sanificante para um total de $570 \mathrm{~g}$ de cada amostra vegetal, distribuídos em porções de $200 \mathrm{~g}, 190 \mathrm{~g}$ e $180 \mathrm{~g}$, em três usos consecutivos.

Foram considerados 4 pontos de coleta das amostras das soluções para a determinação de cloro livre e $\mathrm{pH}: 1$ ) solução inicial (sem uso); 2) solução após o $1^{\circ}$ uso; 3) solução após o $2^{\circ}$ uso; 4) solução após o $3^{\circ}$ uso.

Soluções de hipoclorito de sódio na sanificação do repolho inteiro e fracionado, do tomate e do rabanete, foram coletadas após 3 horas de exposição à luminosidade, temperatura ambiente e ao processo de sanificação em si, correspondendo ao $5^{\circ}$ ponto de coleta.

As amostras foram coletadas em frascos plásticos de $1^{\circ}$ uso, acondicionadas sob refrigeração e as determinações químicas feitas em até 1 hora após as coletas.

\subsubsection{Determinações de cloro livre e pH}

Foram feitas em triplicata, segundo metodologia referida em 3.4.1.2.2 e 3.4.1.2.3. O esquema de uso e reutilizações das soluções está representado na Figura 4.

\subsubsection{Sujidades}

As soluções remanescentes do tratamento sanificante foram avaliadas quanto a quantidade de sujidades advindas durante as três etapas de uso das soluções em hortaliças. As soluções foram filtradas, com uso de filtro apropriado para determinações analíticas e com o auxílio de uma bomba de vácuo. Os filtros foram previamente secos em estufa por $\mathrm{m}$ período mínimo de 2 horas a $180^{\circ} \mathrm{C}$, e registrados os respectivos pesos, determinados em balança analítica. 


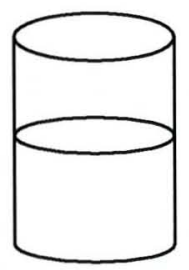

SOLUÇÃO INICIAL $(2100 \mathrm{~mL})$

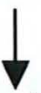

Titulação do Cloro livre
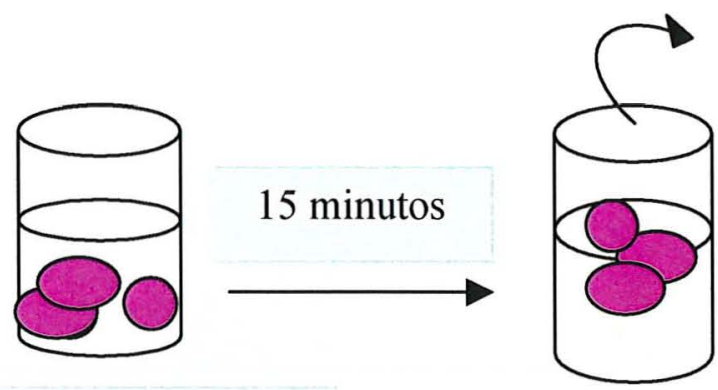

$200 \mathrm{~g} / 2000 \mathrm{~mL}$

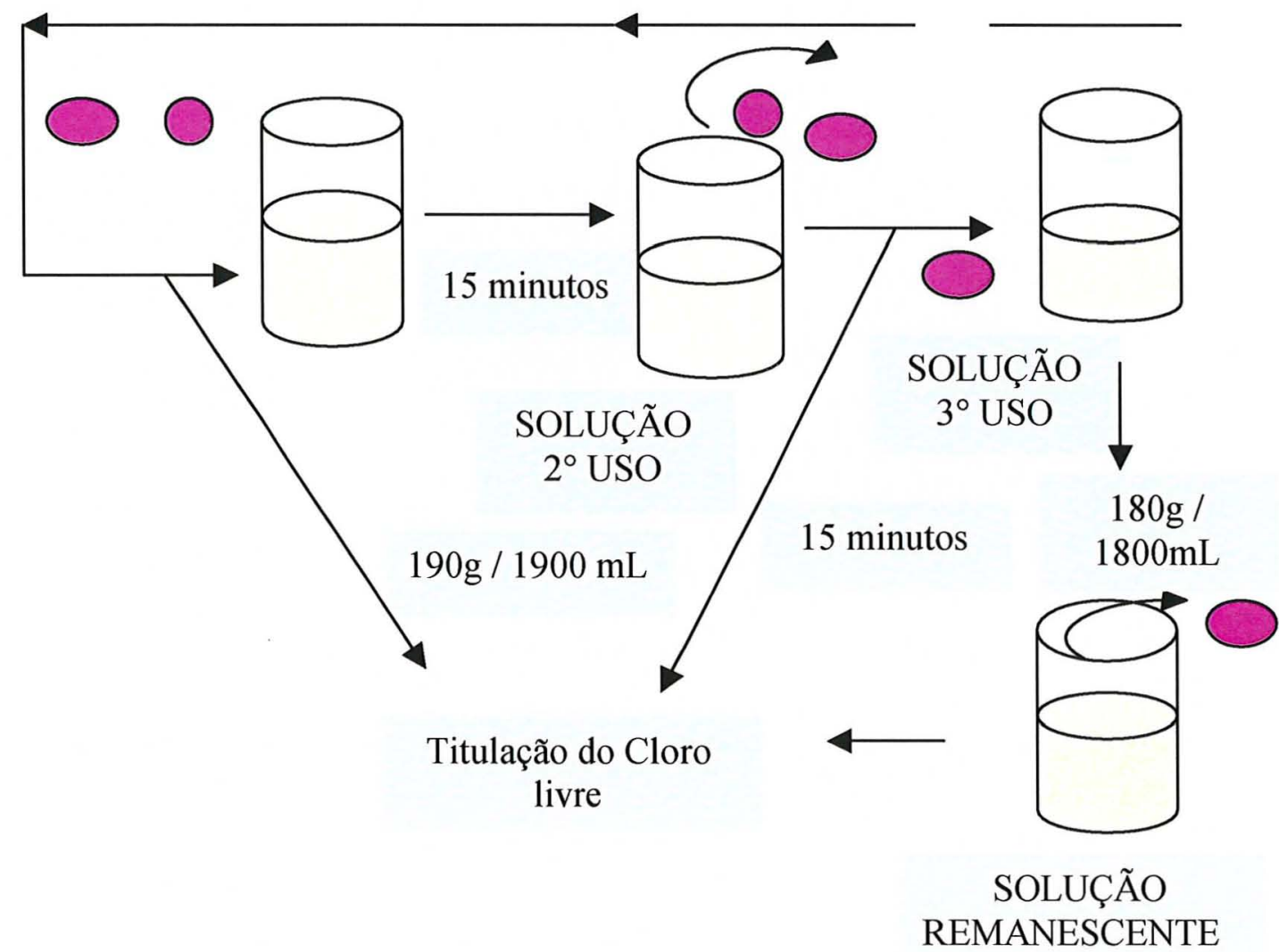

Figura 4 - Esquema para determinação de cloro livre em soluções sanificantes 


\subsubsection{Custo-benefício}

O custo-benefício das soluções foi determinado considerando-se 2 cotações para cada um dos sanificantes; o rendimento das soluções em termos de redução do teor de cloro livre determinado neste trabalho; a relação percentual de custo entre uma e outra solução sanificante; a efetividade microbicida de ambos os sanificantes referida na literatura.

A estimativa de custo das soluções considerou soluções de $\mathrm{NaOCl}$ e $\mathrm{NaDCC}$ a $200 \mathrm{mgCl}_{2} \mathrm{~L}^{-1}$, e a redução de cloro livre em três usos consecutivos. $\mathrm{O}$ cálculo foi feito a partir da quantidade de produto necessária para 1 litro de solução sanificante, com base no teor de cloro ativo referido pelo fabricante. $O$ custo foi expresso em Real para cada uma cotações feitas . 


\section{RESULTADOS E DISCUSSÃO}

\subsection{Qualidade sanitária inicial de hortaliças e eficiência da lavagem}

As amostras das hortaliças avaliadas apenas com a retirada de folhas velhas e danificadas, tiveram contagem total de aeróbios mesófilos próximas a 5 e $7 \log \mathrm{UFC} / \mathrm{g}$, compatível com a contagem esperada para a microbiota natural de hortaliças, e não indicam, por si só, um perigo potencial para a saúde do consumidor (ICMFS, 1995) (Figura 5).

A contagem média para E. coli , considerando que são a grande maioria dos coliformes fecais, ficou dentro dos limites de legislação de $10^{2} \mathrm{NMP} / \mathrm{g}$ coliformes a $45,5^{\circ} \mathrm{C} / \mathrm{g}$ para hortaliças (frescas, sanificadas, refrigeradas ou congeladas para consumo direto) (Brasil, 2001), indicando que foram observadas as boas práticas dentro da cadeia de produção destas hortaliças, principalmente, quanto à contaminação fecal, contribuindo para que chegassem ao ponto final de distribuição em boas condições sanitárias (Beuchat, 2002) (Figuras 6 e7).

As amostras lavadas apresentaram reduções médias para o total de mesófilos aeróbios nas amostras de alface de 1,46 ciclo log, acima das relatadas, de não mais do que 1 ciclo $\log$ (Nascimento \& Catanozi, 2002; Adams et al., 1988 e Leitão et al., 1981). As amostras lavadas de repolho tiveram reduções médias de 0,19 ciclo log, enquanto que as de tomate e rabanete aumento de 0,26 e 0,08 ciclo log, respectivamente, o que pode ser explicado pelo uso do pano descartável utilizado como auxiliar na remoção de sujidades da superfície do vegetal, como veículo de contaminação (Figura $5)$. 


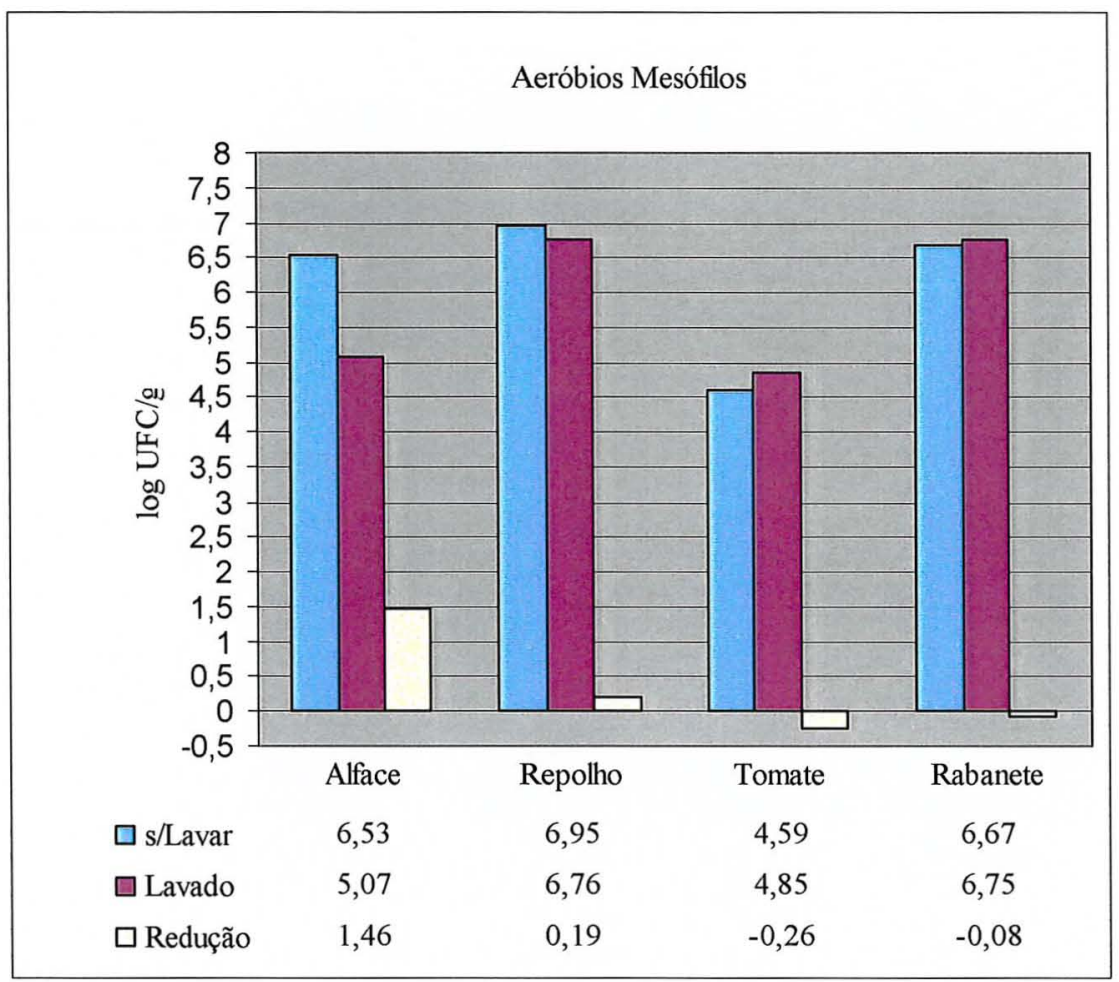

Figura 5 - Contagem total de microrganismos aeróbios mesófilos em hortaliças sem lavar e lavadas na linha de processamento de hortaliças

As reduções médias dos coliformes totais nas hortaliças lavadas de $>0,47$ (rp), 0,59 (al) e 0,67 (to) ciclo log, foram compatíveis com as relatadas por Nascimento \& Catanozi (2002) de >0,28 e 0,81 ciclo log em frutas e hortaliças. A exceção foi do rabanete com redução de $\geq 0,03$ ciclo $\log$ (Figura 6).

As reduções para $E$. coli no rabanete e alface de $>0,30$ a $>0,64$ ciclo $\log$, respectivamente, ficaram acima das verificadas por Nascimento \& Catanozi (2002), em amostras de repolho e alface, com reduções de 0,07 e 0,20 ciclo log. Não houve reduções nas contagens das amostras de tomate lavadas, da mesma forma que aquelas verificadas por Nascimento \& Catanozi (2002) em amostras de uva e morango (Figura 7). 


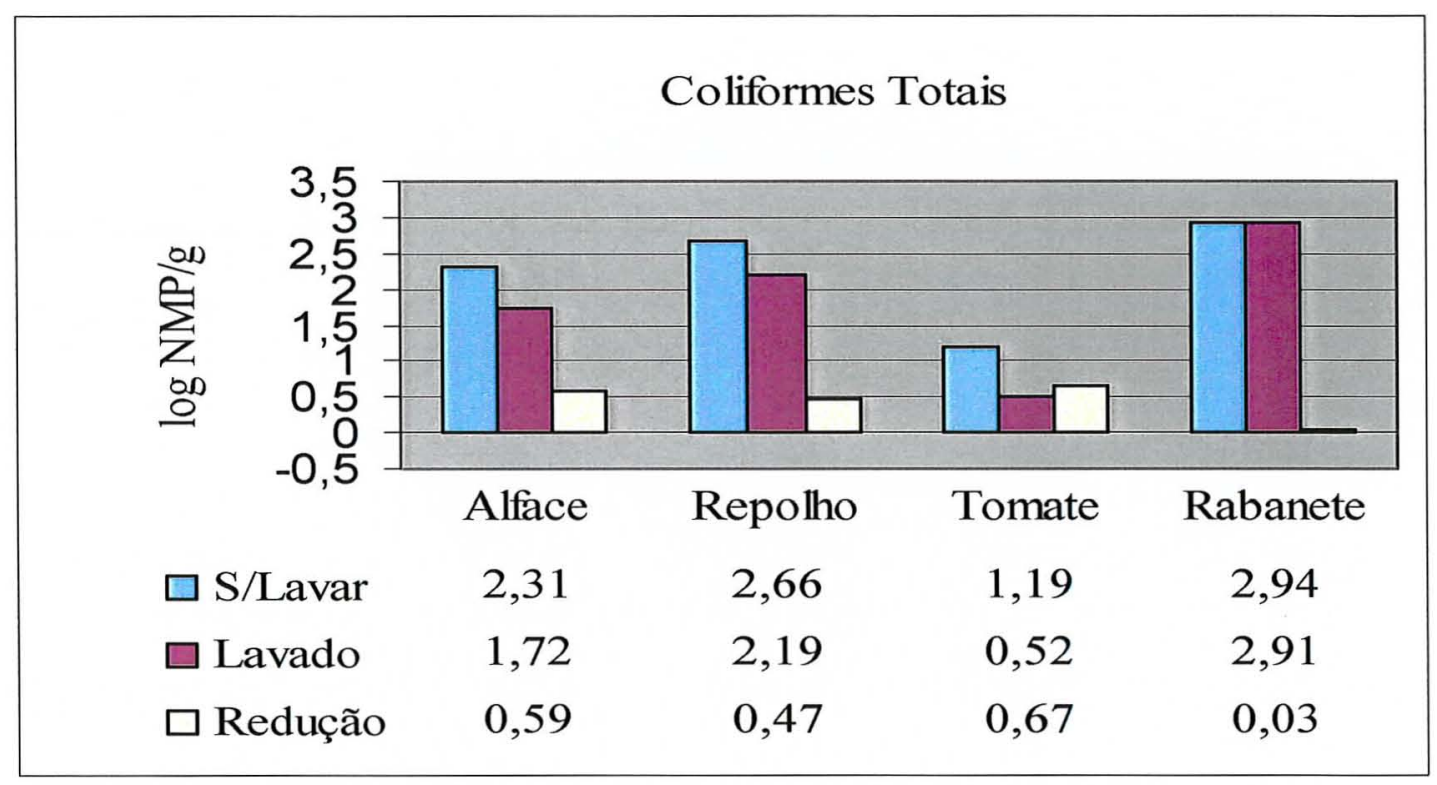

Figura 6 - Contagem de coliformes totais em hortaliças sem lavar e lavadas na linha de processamento de hortaliças

Han et al.(2001), em estudo sobre a redução da Listeria monocytogenes Scott A em pimentas verdes inoculadas artificialmente com contagens de 7 e 8 log UFC/g, observaram que a lavagem simples com água a $20^{\circ} \mathrm{C}$ por 10 minutos reduziu as contagens em 0,4 em superfícies injuriadas e 1,4 em superfícies não lesionadas, sugerindo que superfícies vegetais danificadas podem proteger a bactéria deste tipo de tratamento, favorecendo sua aderência e diminuindo a eficácia do procedimento de lavagem. Resultado semelhante relata Han et al. (2000), citado por Han et al. (2001) em pimentas verdes inoculadas com E coli O157:H7. 


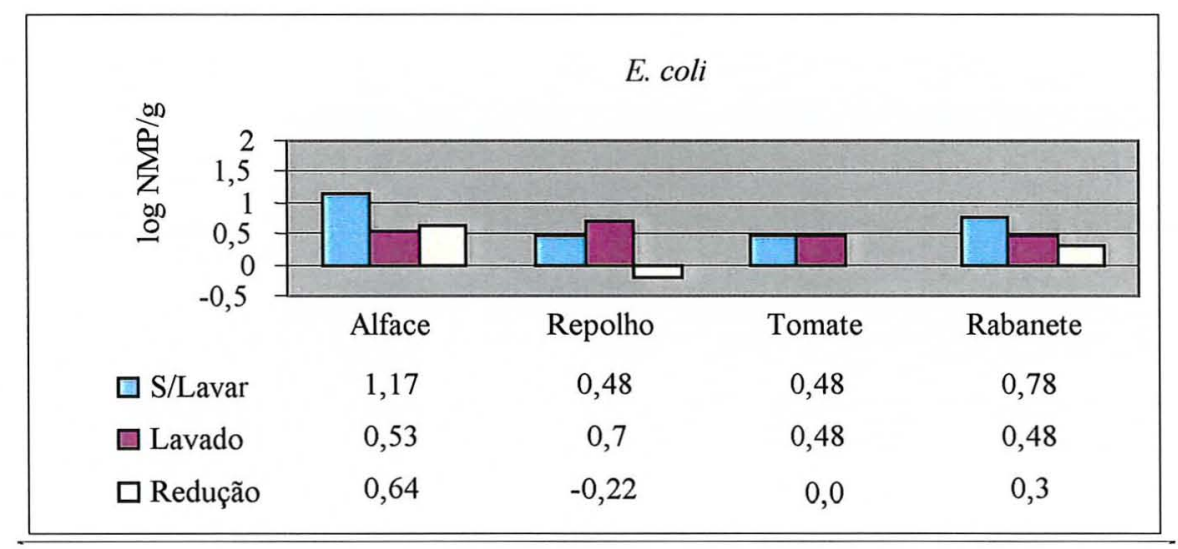

Figura 7 - Contagem de E. coli em hortaliças sem lavar e lavadas na linha de processamento de hortaliças

O aumento verificado em algumas amostras de mesófilos aeróbios, coliformes totais e E.coli, pode ser explicado pela possibilidade de contaminação cruzada ou por contaminação devido às falhas na higienização e manipulação dentro da planta processadora de hortaliças (Martins \& Kuaye; 1996; Hurst, 1995; Marriott, 1985) e que o uso do pano descartável para auxiliar na remoção de sujidades pode representar um potencial veículo de contaminação.

\subsection{Eficácia da sanificação em alface}

Na Figura 8 observa-se que as amostras coletadas no início ( I ) e ao final ( F ) da sanificação tiveram reduções médias no total de mesófilos aeróbios de 0,66 ( I ) e 0,60 ( F ) ciclo log, abaixo do esperado, considerando a eficiência referidas às soluções cloradas de até 2 ciclos log na sanificação de alfaces com hipoclorito de sódio em concentrações 100 e $200 \mathrm{mgL}^{-1}$ de cloro livre por 5 a 30 min (Adams et al., 1988 e Leitão et al., 1981). Nascimento \& Catanozi (2002) alcançaram reduções em amostras de alface de 1,85 e 2,43 e amostras de repolho de 2,00 e 2,48 sanificados, 
respectivamente, com hipoclorito de sódio e dicloroisocianurato de sódio a $200 \mathrm{mg} \mathrm{L}^{-1}$ de cloro livre por um período de 15 minutos.

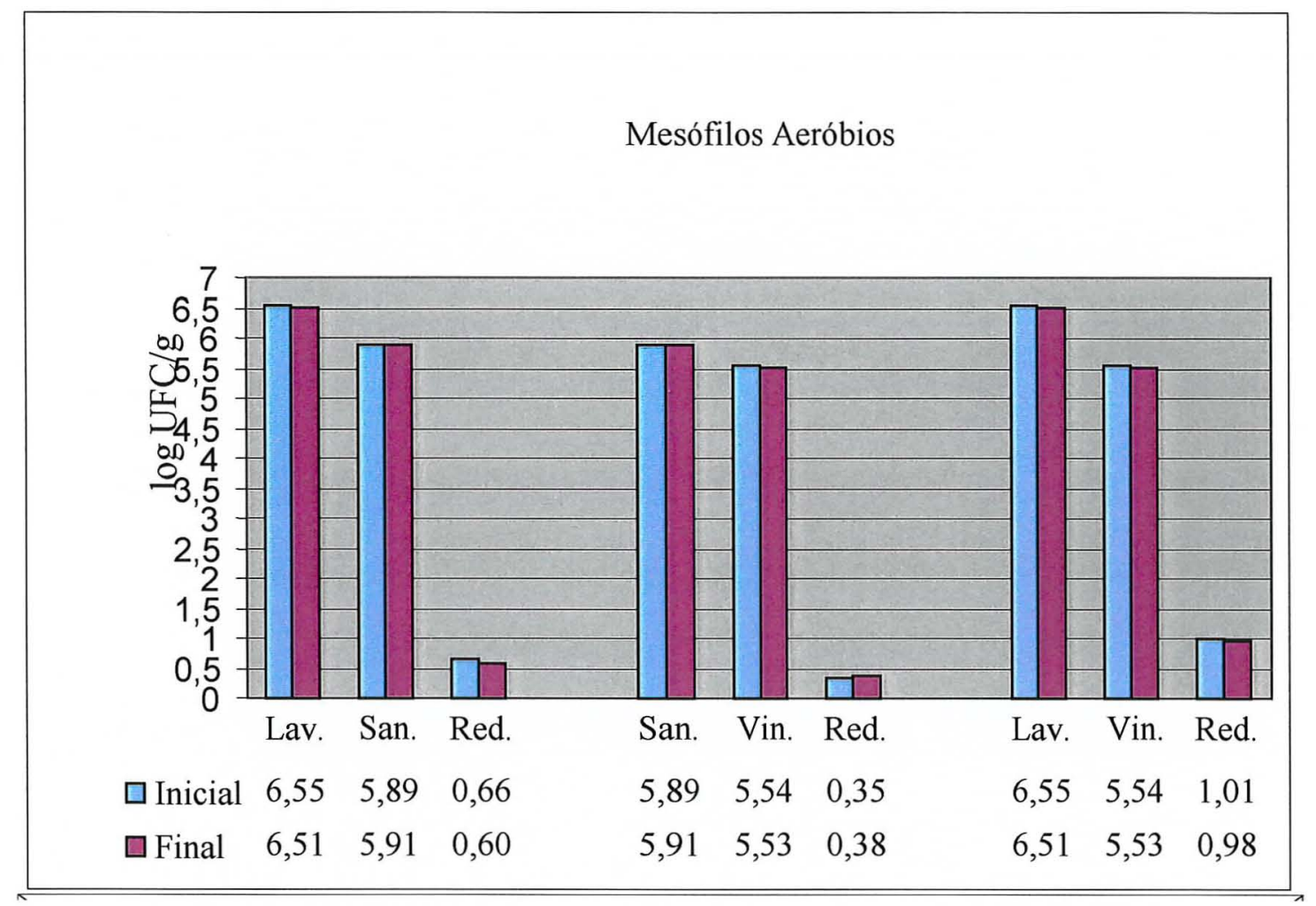

Figura 8 - Contagem total de aeróbios mesófilos em amostras de alface lavadas e sanificadas iniciais e finais

Verifica-se na Figura 9 que as contagens dos coliformes totais em amostras sanificadas I e F em relação às lavadas I e $F$ alcançaram reduções entre $-0,04$ e 0,08 ciclo log, muito pequena, considerando os resultados apresentados por Nascimento \& Catanozi (2002), que obteveram reduções com soluções de hipoclorito de sódio e dicloroisocianurato de sódio a $200 \mathrm{mg} \mathrm{L}^{-1}$ de cloro livre por 15 minutos, respectivamente, para a alface de 1,10 e $>1,14$ e para o repolho $>1,36$ e $>1,31$. Leitão et al. (1981) obtiveram redução de $60 \%$ ( >1 log ) nas contagens de coliformes totais em amostras de alfaces inteiras tratadas com hipoclorito de sódio a $200 \mathrm{mgL}^{-1}$, por $30 \mathrm{~min}$. 


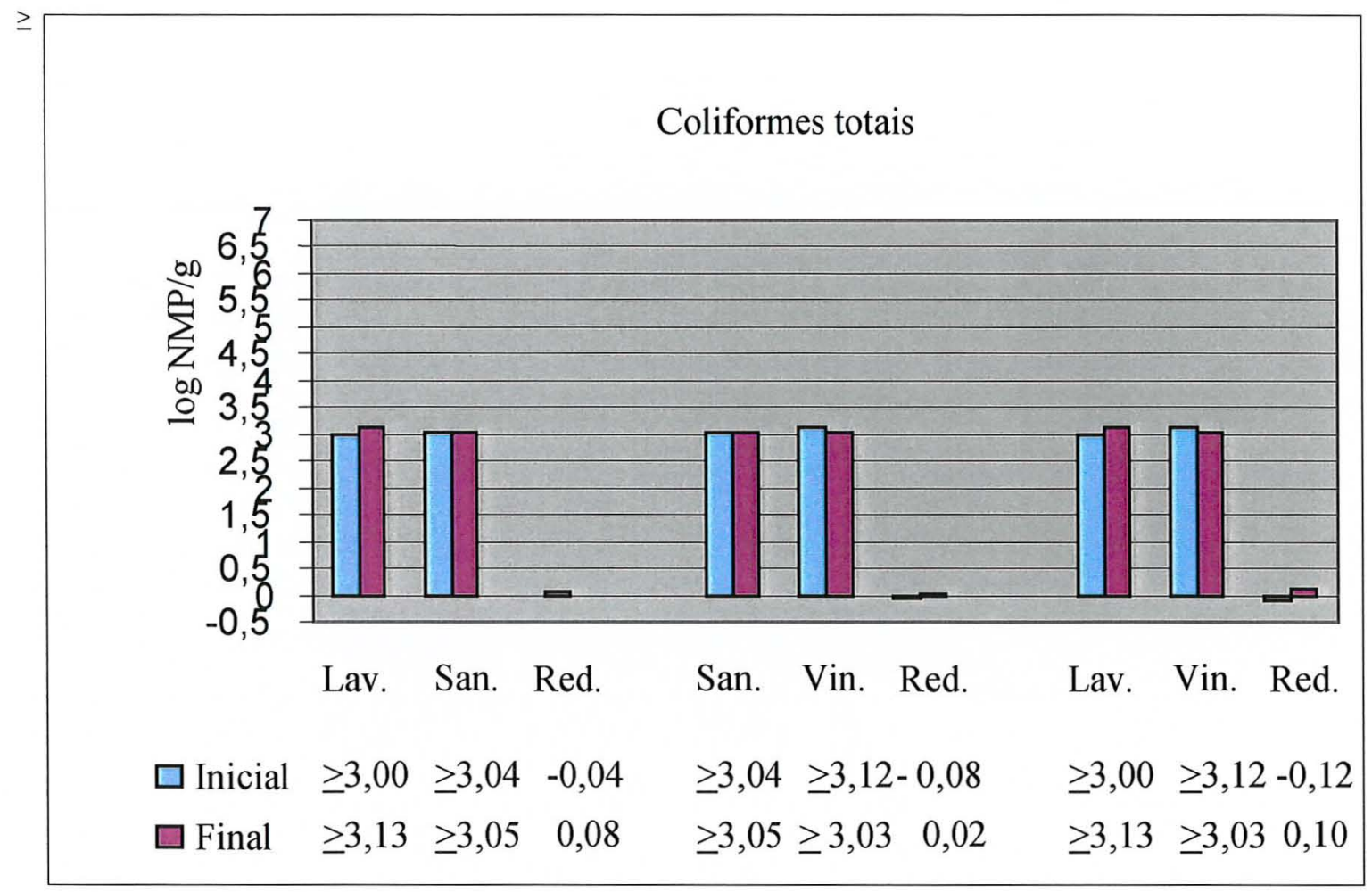

Figura 9 - Contagem de coliformes totais em amostras de alface lavadas e sanificadas iniciais e finais

$\mathrm{Na}$ Figura 10 verifica-se que a média de reduções nas contagem de E. coli em relação às amostras lavadas e sanificadas iniciais de 0,12 ciclo log é compatível com a obtida por Nascimento \& Catanozi (2002) com reduções em alface e repolho de $>0,12$ e >0,43 tratados, respectivamente, com dicloroisocianurato de sódio e hipoclorito de sódio a $200 \mathrm{mg} \mathrm{L}^{-1}$ de cloro livre por 15 minutos. Por outro lado, o aumento de $<0,28$ ciclo log na amostra final pode ser explicado por contaminação cruzada da amostra, favorecida pela proximidade da área de lavagem com a área de sanificação ou a falhas de manipulação durante o processamento. 


\section{E. coli}

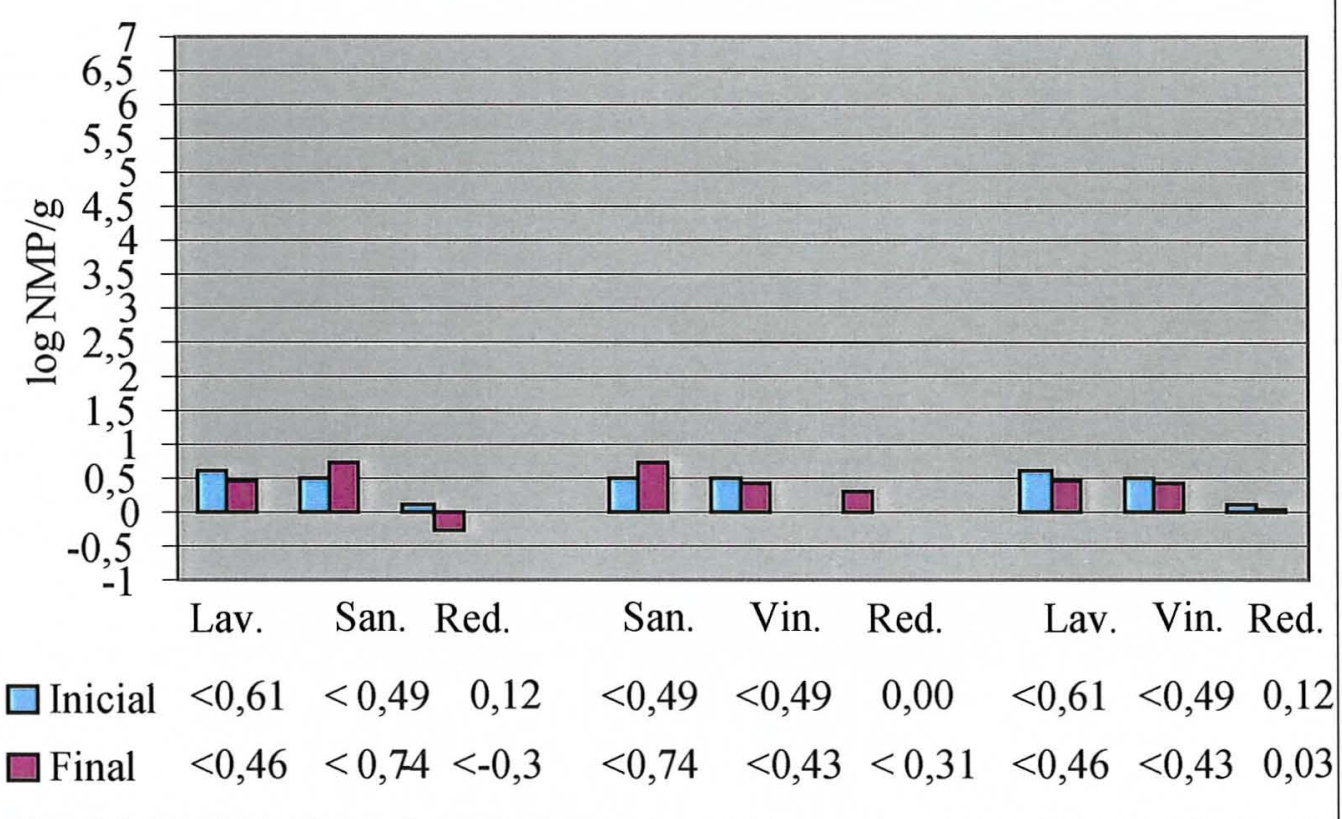

Figura 10 - Contagem de E. coli em amostras de alface lavadas e sanificadas iniciais e finais

A menor eficácia do processo de sanificação observada pode ser explicada, em parte, pelo teor entre 43 a $98 \mathrm{mg} \mathrm{L}^{-1}$ de cloro livre em $75 \%$ das amostras analisadas, abaixo do limite inferior recomendado de $100 \mathrm{mg} \mathrm{L}^{-1}$ de cloro ativo (Tabela 1). No entanto, Leitão et al. (1981) obtiveram reduções médias de $88,6 \%(\simeq 1$ ciclo log ) para o total de mesófilos aeróbios e para coliformes totais, com o uso do hipoclorito de sódio com $50 \mathrm{mg} \mathrm{L}^{-1}$ de cloro livre por período de $30 \mathrm{~min}$.

Aspectos relevantes quanto ao procedimento de sanificação foram observados e que, possivelmente, comprometeram sua eficácia. Um deles é o fato da caixa de sanificação completamente cheia de hortaliça ficar coberta com um peso que a mantém mergulhada e prensar o vegetal em seu interior, impedindo que a solução penetre por entre as folhas. Outro fato a destacar é o volume de solução em relação à quantidade de 
vegetal a sanificar, em torno de $2: 1$ (dois litros de solução para cada quilo de vegetal) por 15 minutos. A relação do volume de solução sanificante e quantidade de vegetal, experimentalmente adotada em trabalhos com sanificação em hortaliças é de 10:1 ou 9:1, por 5 a 10 min (Porto \& Eiroa, 2001; Faber \& Zhang, 1996; Leitão et al. 1981).

Tabela 1. Teor de cloro livre $\mathrm{mg} \mathrm{L}^{-1}$ das soluções cloradas iniciais e finais, quantidade em $\mathrm{Kg}$ de hortaliças, perdas de cloro livre e respectivas médias

\begin{tabular}{ccccc}
\hline Repetição & Solução Inicial & Hortaliças & Solução Final & Redução \\
\hline 1 & 144,98 & - & 128,08 & 12 \\
2 & 117,03 & $67,5^{1}$ & 95,83 & 18 \\
3 & 153,44 & $93,4^{2}$ & 136,92 & 11 \\
4 & - & 36,4 & 145,63 & - \\
5 & 80,09 & $87,5^{2}$ & 78 & 3 \\
6 & 42,76 & $109,4^{2}$ & 55,45 & -30 \\
7 & 64,94 & $71,8^{2}$ & 81,69 & -26 \\
8 & 130,25 & $68^{2}$ & 104,37 & 20 \\
9 & 64,94 & 43 & 56,31 & 13 \\
10 & 93,65 & 43,9 & 80,46 & 14 \\
11 & 89,09 & $108^{2}$ & 59,52 & 33 \\
12 & 118,29 & 35 & 98,21 & 17 \\
13 & 76,4 & 32,9 & 62,47 & 18 \\
14 & 87,49 & 37,5 & 73,07 & 16 \\
Média & $97,18 \pm 33,32^{3}$ & 64,18 & $89,71 \pm 30,77^{3}$ & 8,09 \\
\hline
\end{tabular}

${ }^{1}$ Folhosas e maças

${ }^{2}$ folhosas e tomates

${ }^{3}$ Desvio padrão 
Eiroa \& Porto (1995) avaliaram o efeito de soluç̃os cloradas à base de dicloroisocianurato e hipoclorito de sódio a 100 e $200 \mathrm{mg} \mathrm{L}^{-1}$ de cloro ativo por $15 \mathrm{~min}$ sobre o Vibrio cholerae artificalmente inoculado em folhas de alface, e obtiveram reduções que variaram entre 1,45 a 4,32 ciclo log,

Porto \& Eiroa (2001) estudaram a eficiência de soluções cloradas com 100 $\mathrm{mg} \mathrm{L}^{-1}$ de cloro livre por $15 \mathrm{~min}$ em folhas de alface artificialmente inoculadas com Listeria monocytogenes, conseguindo reduções de 1,9 a 2,4 ciclo log.

Park \& Beuchat (1999) alcançou reduções na população de $E$. coli O157:H7 e Salmonella em torno de 2,6 a 3,8 ciclos log em melões contaminados artificialmente com populações próximas de $9 \mathrm{UFC} / \mathrm{g}$ e tratados com hipoclorito a $200 \mathrm{mg} \mathrm{L}^{-1}$ por 3 minutos, enquanto maiores concentrações de cloro livre foram necessárias $\left(2000 \mathrm{mg} \mathrm{L}^{-1}\right)$ para a inativação de aeróbios mesófilos, bolores e leveduras naturalmente presentes.

\subsection{Eficácia do tratamento complementar com solução de vinagre agrin em alface sanificada}

Nas Figuras 8 e 9 observa-se que a redução média do total de mesófilos aeróbios de 0,35 ( I ) e 0,38 ( F ) e coliformes totais $-0,08$ ( I ) e 0,02 ( F ) ficou abaixo dos resultados de Eiroa e Porto (1996) na sanificação de amostras de alface inoculadas artificialmente com Vibrio cholerae e tratadas com hipoclorito de sódio a $100 \mathrm{mg} \mathrm{L}^{-1}$ por $15 \mathrm{~min}$, alcançando reduções de 1,0 e 0,8 , respectivamente. No entanto, para a $E$. coli em amostra final a redução foi de 0,31 ciclo $\log$ (figura 10), superando 0,1 ciclo $\log$, resultado alcançado por Eiroa \& Porto (1996) do estudo acima referido.

Leitão et al. (1985) obtiveram resultados bem acima dos verificados neste trabalho, quanto às reduções do total de aeróbios mesófilos e coliformes totais em amostras de alface tratadas com vinagre em solução a $2 \%$, alcançando reduções de $98 \%$ ( $\simeq 2$ ciclo $\log$ ) e $99,8 \%$ ( $\simeq 3$ ciclos $\log$ ), respectivamente. 
Eiroa \& Porto (1995) avaliaram o efeito de soluções de vinagre a $2 \%, 4 \%$ e $6 \%$ sobre o Vibrio cholerae artificalmente inoculado em folhas de alface, obtendo reduções, respectivamnete, de $3,41,>4,4$ e 5,9 ciclos log .

Assim, pode-se afirmar que o procedimento de uso do vinagre foi pouco eficaz como complemento de higienização da alface, podendo ser explicada pela relação volume de solução e quantidade de vegetal de 5:1,5, abaixo de 9 e 10:1, experimentalmente adotada nos trabalhos citados, e pelo teor de ácido acético de $0,11 \%$ (Tabela 2), também menor em relação aos teores experimentalmente adotados nos trabalhos citados.

Por outro lado, embora seja comprovadamente bactericida, o vinagre não tem a aprovação legal como sanificante, e sim como complemento de limpeza para auxiliar a remoção de ovos e larvas de parasitas aderidos à superfície do vegetal (São Paulo, 1999).

A associação de ambos os tratamentos não significou um aumento na redução das contagens, para o total de aeróbios mesófilos em torno de 1 ciclo log, para os coliformes totais não maior que 0,1 ciclo $\log$ e para a $E$. coli entre 0,03 e 0,12 ciclo $\log$, conforme se verifica nas Figuras 6, 7 e 8.

Esses resultados corroboram aqueles obtidos por Eiroa e Porto (1996) em que a associação do tratamento com solução de hipoclorito de sódio a $100 \mathrm{mg} \mathrm{L}^{-1}$ de cloro ativo por 15 minutos, seguido do tratamento com solução de vinagre a $6 \%$, sobre o Vibrio cholerae alterou muito pouco a eficiência do tratamento quando comparado às reduções alcançadas apenas com o uso do hipoclorito $\mathrm{pH} 7,00$, alcançando ambos os tratamentos reduções, respectivamente, de 3,4 e 3,0 ciclo log. Além disso, constataram que maiores reduções foram conseguidas apenas com o vinagre a $6 \%$, com reduções de 5,5 a 6,5 ciclo log. 
Tabela 2. Determinações químicas de soluções de vinagre agrin no tratamento de alface

\begin{tabular}{ccccc}
\hline & Amostras & Acidez Total & Ac.Acético & $\mathrm{pH}$ \\
\hline 1 & $\mathrm{I}^{\mathbf{1}}$ & $\mathrm{NR}^{3}$ & $\mathrm{NR}$ & - \\
& $\mathrm{F}^{2}$ & $\mathrm{NR}$ & $\mathrm{NR}$ & - \\
2 & $\mathrm{I}$ & $\mathrm{NR}$ & $\mathrm{NR}$ & 3,80 \\
& $\mathrm{~F}$ & $\mathrm{NR}$ & $\mathrm{NR}$ & 3,90 \\
3 & $\mathrm{I}$ & $\mathrm{NR}$ & $\mathrm{NR}$ & 3,30 \\
& $\mathrm{~F}$ & $\mathrm{NR}$ & $\mathrm{NR}$ & 3,50 \\
4 & $\mathrm{I}$ & $\mathrm{NR}$ & $\mathrm{NR}$ & 3,46 \\
& $\mathrm{~F}$ & $\mathrm{NR}$ & $\mathrm{NR}$ & 3,43 \\
5 & $\mathrm{I}$ & $\mathrm{NR}$ & $\mathrm{NR}$ & 3,76 \\
& $\mathrm{~F}$ & $\mathrm{NR}$ & $\mathrm{NR}$ & 3,59 \\
6 & $\mathrm{I}$ & $\mathrm{NR}$ & $\mathrm{NR}$ & 3,44 \\
& $\mathrm{~F}$ & $\mathrm{NR}$ & $\mathrm{NR}$ & 3,55 \\
7 & $\mathrm{I}$ & $\mathrm{NR}$ & $\mathrm{NR}$ & 5,06 \\
& $\mathrm{~F}$ & $\mathrm{NR}$ & $\mathrm{NR}$ & 4,11 \\
8 & $\mathrm{I}$ & $\mathrm{NR}$ & $\mathrm{NR}$ & 3,37 \\
& $\mathrm{~F}$ & $\mathrm{NR}$ & $\mathrm{NR}$ & 3,91 \\
9 & $\mathrm{I}$ & $\mathrm{NR}$ & $\mathrm{NR}$ & $\mathrm{NR}$ \\
& $\mathrm{F}$ & $\mathrm{NR}$ & $\mathrm{NR}$ & $\mathrm{NR}$ \\
10 & $\mathrm{I}$ & $\mathrm{NR}$ & $\mathrm{NR}$ & $\mathrm{NR}$ \\
& $\mathrm{F}$ & $\mathrm{NR}$ & $\mathrm{NR}$ & $\mathrm{NR}$ \\
11 & $\mathrm{I}$ & 0,211 & 0,094 & 3,51 \\
& $\mathrm{~F}$ & 0,203 & 0,120 & 3,38 \\
12 & $\mathrm{I}$ & $\mathrm{NR}$ & $\mathrm{NR}$ & $\mathrm{NR}$ \\
& $\mathrm{F}$ & 0,194 & 0,130 & 3,24 \\
13 & $\mathrm{I}$ & 0,195 & 0,124 & 3,26 \\
& $\mathrm{~F}$ & 0,195 & 0,120 & 3,25 \\
14 & $\mathrm{I}$ & 0,167 & 0,088 & 2,79 \\
& $\mathrm{~F}$ & $\mathrm{NR}$ & $\mathrm{NR}$ & $\mathrm{NR}$ \\
Média & $\mathrm{I}$ & $0,19 \pm 0,02^{4}$ & $0,11 \pm 0,02$ & $3,58 \pm 0,59$ \\
& $\mathrm{~F}$ & $0,20 \pm 0,00$ & $0,12 \pm 0,01$ & $3,56 \pm 0,30$ \\
\hline
\end{tabular}

${ }^{1}$ Amostra inical

${ }^{2}$ Amostra final

${ }^{3}$ Não realizado

${ }^{4}$ Desvio padrão 
Entre todos os tratamentos, a lavagem em água corrente foi o procedimento que mais reduziu as contagens microbianas de uma maneira geral nas amostras de alface inteira, com reduções de 1,46 ciclos log (Figura 5 a 6). Este fato pode estar relacionado à remoção da sujeira e das bactérias não aderidas, enquanto o processo de sanificação ajudou somente na remoção das células aderidas ao vegetal.

É relevante ressaltar que as diferenças nos resultados encontrados neste estudo em relação aos da literatura, são justificadas pelo fato de não serem trabalhos cujo objetivo fosse avaliar o procedimento em escala comercial, e sim a eficiência dos produtos sob diversas condições, e cujo controle de variáveis ligadas à questão higiênico-sanitárias são possíveis. Portanto, estudos de campo são importantes para que possamos avaliar de forma mais objetiva os procedimentos adotados dentro de uma unidade de processamento de hortaliças de consumo cru e assim, poder a melhorar a eficácia do controle microbiológico em hortaliças consumidas cruas.

\subsection{Avaliação do kit dosador de cloro livre como instrumento de monitoração do teor crítico de cloro livre em soluções}

Os valores titulados identificaram $67 \%$ das amostras $(26 \mathrm{em} \mathrm{38)}$ abaixo do nível crítico de controle de $100 \mathrm{Cl}_{2} \mathrm{mgL}^{-1}$, enquanto que a fita dosadora identificou apenas $20 \%$ ( $8 \mathrm{em} \mathrm{38)}$, conforme verificamos na Tabela 3. Mesmo considerando uma perda de cloro livre nas soluções até a sua titulação (provavelmente inferior a média de 8\% verificada durante o período 3 horas para a sanificação das hortaliças) essa diferença indica uma confiabilidade para menos na avaliação do nível crítico de cloro livre em soluções, e a avaliações não confiáveis das condições de uso das soluções cloradas, podendo comprometer a eficácia do procedimento de higienização (Tabela 3). 
Tabela 3. Teor de cloro em soluções cloradas iniciais, intermediárias e finais determinadas por titulação e aferidas por fita dosadora e a correspondência de ambos os valores na identificação do nível crítico de controle

\begin{tabular}{|c|c|c|c|c|c|c|}
\hline Repetição & Amostra & Titulações & \multicolumn{4}{|c|}{ Kit dosador de cloro } \\
\hline & & & $>50$ & 50 a100 & 100 a 200 & $<200$ \\
\hline \multirow[t]{3}{*}{1} & $\mathrm{I}^{1}$ & 144,98 & NR & NR & NR & NR \\
\hline & $M^{2}$ & 145,63 & NR & NR & NR & NR \\
\hline & $\mathrm{F}^{3}$ & 128,08 & NR & NR & NR & NR \\
\hline \multirow[t]{3}{*}{2} & I & 117,03 & & $\mathbf{x}$ & & \\
\hline & M & 101,42 & & $\mathbf{x}$ & & \\
\hline & $\mathrm{F}$ & 95,83 & & $\mathbf{x}$ & & \\
\hline \multirow[t]{3}{*}{3} & I & 153,44 & & & $\mathbf{x}$ & \\
\hline & M & 144,33 & & & $\mathbf{x}$ & \\
\hline & $\mathrm{F}$ & 136,92 & & & $\mathbf{x}$ & \\
\hline \multirow[t]{3}{*}{4} & I & NR & NR & NR & NR & NR \\
\hline & M & 161,24 & & & $\mathbf{x}$ & \\
\hline & $\mathrm{F}$ & 145,63 & & & $\mathbf{x}$ & \\
\hline \multirow[t]{3}{*}{5} & $\mathrm{I}$ & 80,09 & & & $\mathbf{x}$ & \\
\hline & M & 84,65 & & & $\mathbf{x}$ & \\
\hline & $\mathrm{F}$ & 78,00 & & & $\mathbf{x}$ & \\
\hline \multirow[t]{3}{*}{6} & I & 42,76 & $\mathbf{x}$ & & & \\
\hline & M & 43,99 & & $\mathbf{x}$ & & \\
\hline & $\mathrm{F}$ & 55,45 & & $\mathbf{x}$ & & \\
\hline \multirow[t]{3}{*}{7} & I & 64,94 & $\mathbf{x}$ & & & \\
\hline & M & 62,47 & & $\mathbf{x}$ & & \\
\hline & F & 81,69 & & & $\mathbf{x}$ & \\
\hline \multirow[t]{3}{*}{8} & I & 130,25 & & & $\mathbf{x}$ & \\
\hline & $\mathrm{M}$ & 114,97 & & & $\mathbf{x}$ & \\
\hline & F & 104,37 & & & $\mathbf{x}$ & \\
\hline \multirow[t]{3}{*}{9} & I & 64,94 & & & $\mathbf{x}$ & \\
\hline & $\mathrm{M}$ & 56,68 & & & $\mathbf{x}$ & \\
\hline & $\mathrm{F}$ & 56,31 & & & $\mathbf{x}$ & \\
\hline \multirow[t]{3}{*}{10} & I & 93,65 & & & $\mathbf{x}$ & \\
\hline & $\mathrm{M}$ & 90,32 & & & $\mathbf{x}$ & \\
\hline & $\mathrm{F}$ & 80,46 & & & $\mathbf{x}$ & \\
\hline \multirow[t]{3}{*}{11} & I & 89,09 & & & $\mathbf{x}$ & \\
\hline & $\mathrm{M}$ & 68,14 & & & $\mathbf{x}$ & \\
\hline & $\mathrm{F}$ & 59,52 & & & $\mathbf{x}$ & \\
\hline
\end{tabular}


Tabela 3. Teor de cloro em soluções cloradas iniciais, intermediárias e finais determinadas por titulação e aferidas por fita dosadora e a correspondência de ambos os valores na identificação do nível crítico de controle

\begin{tabular}{|c|c|c|c|c|c|c|}
\hline \multirow[t]{2}{*}{ Repetição } & \multirow[t]{2}{*}{ Amostra } & \multirow[t]{2}{*}{ Titulações } & \multicolumn{4}{|c|}{ Kit dosador de cloro } \\
\hline & & & $>50$ & $50 \mathrm{a} 100$ & 100 a 200 & $<200$ \\
\hline \multirow[t]{3}{*}{12} & I & 118,29 & & & $\mathrm{x}$ & \\
\hline & M & 110,04 & & & $\mathrm{x}$ & \\
\hline & $\mathrm{F}$ & 98,21 & & & $\mathrm{x}$ & \\
\hline \multirow[t]{3}{*}{13} & I & 76,40 & & & $\mathrm{x}$ & \\
\hline & M & 69,37 & & & $\mathrm{x}$ & \\
\hline & F & 62,47 & & & $x$ & \\
\hline \multirow[t]{3}{*}{14} & I & 87,49 & & & $\mathrm{x}$ & \\
\hline & M & 82,56 & & & $\mathrm{x}$ & \\
\hline & $\mathrm{F}$ & 73,07 & & & $\mathrm{x}$ & \\
\hline
\end{tabular}

$\begin{array}{lrr}\text { Soluções }<100 \mathrm{mg} \mathrm{L}^{-1} & 26 \mathrm{em} 38 & 8 \mathrm{em} 38\end{array}$

${ }^{1}$ Solução inicial

${ }^{2}$ Solução intermediaria

${ }^{3}$ Solução final

4.6 Estudo laboratorial com soluções sanificantes no tratamento de hortaliças

\subsubsection{Cloro livre}

A concentração nominal de cloro livre para as soluções de NaDCC foi estabelecida segundo recomendação do fabricante para atingir a concentração mínima de $130 \mathrm{Cl}_{2} \mathrm{mg} \mathrm{L}^{-1}\left(1,5 \mathrm{~g} \mathrm{~L}^{-1}\right)$. Os valores obtidos na titulação foram de $155 \mathrm{Cl}_{2} \mathrm{mg} \mathrm{L}^{-1}$, 19\% acima da concentração nominal mínima referida (Tabela 5).

Por sua vez, a concentração nominal de cloro livre das soluções de $\mathrm{NaOCl}$, por não apresentar uma indicação de uso pelo fabricante, foi determinada para atingir a faixa referida por legislação. Após as titulações, obteve média inicial de $125 \mathrm{Cl}_{2} \mathrm{mg} \mathrm{L}^{-}$ ${ }^{1}$, menor $40 \%$ da concentração nominal desejada de $207 \mathrm{Cl}_{2} \mathrm{mg} \mathrm{L}^{-1}$ (Tabela 5). 
Tabela 5. Concentração de cloro livre em soluções iniciais de dicloroisocianurato de sódio e hipoclorito de sódio

\begin{tabular}{ccc}
\hline & Solução de NaDCC & Solução de NaOCl \\
\hline 1 & 153 & 128 \\
2 & 154 & 123 \\
3 & 143 & 128 \\
4 & 149 & 116 \\
5 & $\mathrm{NR}$ & 126 \\
6 & 178 & 127 \\
Média & $155,4 \pm 13,4^{1}$ & $125 \pm 5,0$ \\
\hline
\end{tabular}

${ }^{1}$ Desvio padrão

Embora ambas as soluções tenham atendido à concentração recomendada por legislação de 100 a $250 \mathrm{Cl}_{2} \mathrm{mg} \mathrm{L}^{-1}$, verificou-se que o teor de cloro ativo referido pelo fabricante pode não atender ao teor de cloro livre desejado para a solução, sendo um problema mais grave no caso do hipoclorito, que foi inferior.

É bem conhecida e reportada a instabilidade do hipoclorito quanto aos fatores ligados a sua estocagem, como a exposição à luz e ao calor. Assim, o $\mathrm{NaOCl}$ utilizado neste trabalho, provavelmente, esteve sujeito a condições de produção, armazenamento e embalagem que não propiciaram a preservação do teor de cloro ativo referido pelo fabricante até a data de validade do produto (Aguiar et al., 2002; Nicoletti et al., 1996; Nicoletti \& Magalhães, 1995; Paiva et al., 1989).

É de grande importância que o produto adquirido esteja dentro da faixa percentual de cloro ativo referida para que não venha a comprometer a eficiência e o rendimento da solução sanificante. Assim, um teste inicial de titulação de cloro livre em um produto sanificante deve ser um primeiro passo para a garantia de um procedimento de sanificação eficaz, especialmente para o hipoclorito de sódio.

Em geral, ao longo do processo de sanificação da alface (al), repolho (rp), rabanete (rb) e tomate (to), ambas as soluções cloradas acumularam reduções no teor de cloro livre, conforme se verifica-na Tabela 5. 
Ao final do terceiro uso, as soluções de cada uma das hortaliças inteiras apresentaram reduções médias percentuais de cloro livre para $\mathrm{NaDCC}$ e $\mathrm{NaOCl}$, respectivamente, de $10,7 \%$ e $18,5 \%$ (al); $18,2 \%$ e $16,0 \%$ (rp); $8,3 \%$ e $15,0 \%$ (rb); $3,0 \%$ e $-3,1 \%$ (to) (dois usos); para as fracionadas, de $25,1 \%$ e $43,1 \%$ (al) e $31,2 \%$ e $57,9 \%(\mathrm{rp})$. Em média, as reduções entre as soluções das 4 hortaliças inteiras foram de $10,1 \%$ para o $\mathrm{NaDCC}$ e $11,6 \%$ para o $\mathrm{NaOCl}$; enquanto entre as soluções das 2 hortaliças fracionadas, de 28,1\% para o NaDCC e 50,5\% para o $\mathrm{NaOCl}$ (Tabela 6).

Embora, individualmente as soluções de $\mathrm{NaOCl}$ para as hortaliças inteiras (I) tenham apresentado as maiores reduções de cloro livre para a alface e o rabanete, a média de redução das 4 soluções vegetais praticamente se equipara às reduções das 4 soluções dos vegetais de $\mathrm{NaDCC}$, com diferença de pouco mais de $1 \%$. Já nos fracionados $(\mathrm{F})$, a diferença de redução foi sempre maior para o $\mathrm{NaOCl}$, em média 22,4\% maior em relação ao $\mathrm{NaDCC}$ (Tabela 6).

A avaliação dos 2 sistemas de tratamento das hortaliças, em cada uma das 3 etapas de uso, indica que a perda de cloro ativo foi freqüentemente maior nas soluções de $\mathrm{NaOCl}$ do que nas soluções de $\mathrm{NaDCC}$ (Tabelas 7, 8 e 9).

Após o $1^{\circ}$ uso, as reduções médias percentuais de cloro livre nas soluções de $\mathrm{NaDCC}$ e $\mathrm{NaOCl}$ foram, respectivamente, para as hortaliças inteiras de 1,0\% e 3,1\% (al), $5,4 \%$ e $3,4 \%$ (rp), $6,2 \%$ e $3,5 \%$ (rb), NR e -5,8\% (to); para as fracionadas, de 7,2\% e $9,8 \%$ (al); $6,8 \%$ e $21,2 \%$ (rp). A média percentual entre todas as soluções para o $\mathrm{NaDCC}$ e o $\mathrm{NaOCl}$ foi, respectivamente, para os vegetais inteiros de 4,2\% e 1,1\%; para os fracionados de 7,0\% e $15,5 \%$. A diferença de consumo de cloro livre entre as médias das soluções foi 3,1\% maior para o NaDCC, para os vegetais inteiros, e 8,5\% maior $\mathrm{NaOCl}$, para os vegetais fracionados (Tabela 7). 
Tabela 6. Redução de cloro livre em soluções de sanificação em hortaliças após o terceiro uso

\begin{tabular}{lcccc}
\hline & $\mathrm{NaDCC}$ & \multicolumn{3}{c}{$\mathrm{NaOCl}$} \\
\hline & $\mathrm{mg} \mathrm{L}^{-1}$ & $\%$ & $\mathrm{mg} \mathrm{L}^{-1}$ & $\%$ \\
Alface inteira & 16,3 & 10,7 & 23,6 & 18,5 \\
Repolho Inteiro & 26,2 & 18,2 & 20,5 & 16,0 \\
Rabanete & 14,8 & 8,3 & 19,0 & 15,0 \\
Tomate & $5,6^{1}$ & 3,0 & $-3,8$ & $-3,1$ \\
$\quad$ Média & 15,7 & 10,1 & $-14,8$ & $-11,6$ \\
$\quad$ & & & & \\
Alface Fracionada & 38,5 & 25,1 & 53,0 & 43,1 \\
Repolho Fracionado & 46,4 & 31,2 & 67,0 & 57,9 \\
$\quad$ Média & 42,5 & 28,1 & 60,0 & 50,5 \\
\hline
\end{tabular}

${ }^{1}$ Valores relativos a dois usos da solução

Após o $2^{\circ}$ uso, as reduções médias percentuais de cloro livre nas soluções de $\mathrm{NaDCC}$ e $\mathrm{NaOCl}$ foram, respectivamente, para vegetais inteiros de 5,2\% e 7,8\% (al), $2,2 \%$ e $9,1 \%$ (rp), $1,3 \%$ e $1,3 \%$ (rb), $2,1 \%$ e $3,1 \%$ (to); enquanto para vegetais fracionados de $10,9 \%$ e $21,4 \%$ (al); $16,9 \%$ e $16,2 \%$ (rp). A média percentual entre todas as soluções para o $\mathrm{NaDCC}$ de $\mathrm{NaOCl}$ foi, respectivamente, para os vegetais inteiros de 2,7\% e 5,3\%; para os fracionados de 13,9\% e 18,8\%. Assim, a diferença de consumo de cloro livre entre as médias das soluções foi $2,6 \%$ (I) e $4,9 \%$ (F) maior para o $\mathrm{NaOCl}$ (Tabela 8). 
Tabela 7. Reduções de cloro livre em soluções de sanificação de hortaliças após o $1^{\circ}$ uso e suas respectivas médias

\begin{tabular}{lcccccc}
\hline & \multicolumn{3}{c}{$\mathrm{Cl}_{2} \mathrm{mg} \mathrm{L}^{-1}$} & \multicolumn{3}{c}{$\%$} \\
\hline & $\mathrm{NaDCC}$ & $\mathrm{NaOCl}$ & Diferença & $\mathrm{NaDCC}$ & $\mathrm{NaOCl}$ & Diferença \\
Alface inteira & 1,5 & 4,0 & $-2,5$ & 1,0 & 3,1 & $-2,1$ \\
Repolho Inteiro & 7,8 & 4,4 & 3,4 & 5,4 & 3,4 & 2,0 \\
Rabanete & 11,0 & 4,4 & 6,6 & 6,2 & 3,5 & 2,7 \\
Tomate & $\mathrm{NR}$ & $-7,3$ & - & $\mathrm{NR}$ & $-5,8$ & - \\
$\quad$ Média & 6,8 & 1,4 & 5,4 & 4,2 & 1,1 & 3,1 \\
$\quad$ & & & & & & \\
Alface Fracionada & 11,0 & 12,0 & $-1,0$ & 7,2 & 9,8 & $-2,6$ \\
Repolho Fracionado & 10,1 & 24,5 & $-14,4$ & 6,8 & 21,2 & $-14,4$ \\
$\quad$ Média & 10,6 & 18,3 & $-7,7$ & 7,0 & 15,5 & $-8,5$ \\
\hline
\end{tabular}

NR - Não realizado

Após o $3^{\circ}$ uso, as soluções de $\mathrm{NaDCC}$ e $\mathrm{NaOCl}$, apresentaram reduções médias percentuais de cloro livre, respectivamente, para hortaliças inteiras de $4,9 \% \mathrm{e}$ $8,7 \%$ (al), $11,6 \%$ e $4,4 \%$ (rp), $1,0 \%$ e $10,8 \%$ (rb), $1,0 \%$ e $-0,6 \%$ (to), enquanto para vegetais fracionados de $9,4 \%$ e $19,8 \%$ (al); $11,1 \%$ e $36,6 \%(\mathrm{rp})$. A média percentual entre todas as soluções de $\mathrm{NaDCC}$ e $\mathrm{NaOCl}$ foi, respectivamente, para as hortaliças inteiras de 4,6\% e 5,8\%, para as fracionadas, de 10,3\% e 28,1\%. Assim, a diferença de consumo de cloro livre entre as médias das soluções foi $1,2 \%$ (I) e $17,8 \%$ (F) maiores para o $\mathrm{NaOCl}$ (Tabela 9). 
Tabela 8 Reduções de cloro livre em soluções de sanificação em hortaliças após o $2^{\circ}$ uso

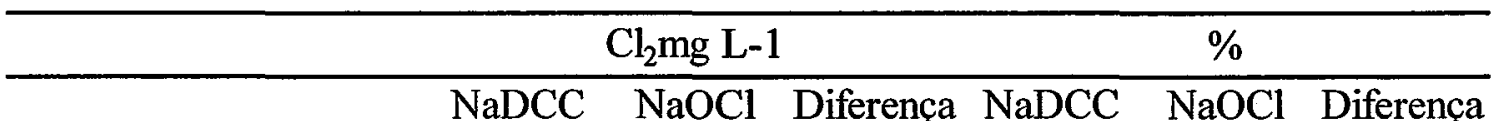

\begin{tabular}{lcccccc} 
Alface inteira & 7,8 & 9,7 & $-1,9$ & 5,2 & 7,8 & $-2,6$ \\
Repolho Inteiro & 3,0 & 11,2 & $-8,2$ & 2,2 & 9,1 & $-6,9$ \\
Rabanete & 2,2 & 1,6 & 0,6 & 1,3 & 1,3 & 0,0 \\
Tomate & 3,8 & 4,2 & $-0,4$ & 2,1 & 3,1 & $-1,0$ \\
$\quad$ Média & 4,2 & 6,7 & $-2,5$ & 2,7 & 5,3 & $-2,6$ \\
& & & & & & \\
Alface Fracionada & 15,5 & 23,7 & $-8,2$ & 10,9 & 21,4 & $-10,5$ \\
Repolho Fracionado & 23,5 & 14,8 & 8,7 & 16,9 & 16,2 & 0,7 \\
$\quad$ Média & 19,5 & 19,3 & 0,3 & 13,9 & 18,8 & $-4,9$ \\
\hline
\end{tabular}

Tabela 9. Reduções de cloro livre em soluções de sanificação de hortaliças após o $3^{\circ}$ uso

\begin{tabular}{lcccccc}
\hline & \multicolumn{3}{c}{$\mathrm{Cl}_{2} \mathrm{mg} \mathrm{L}^{-1}$} & \multicolumn{3}{c}{$\%$} \\
\hline & $\mathrm{NaDCC}$ & $\mathrm{NaOCl}$ & Diferença & $\mathrm{NaDCC}$ & $\mathrm{NaOCl}$ & Diferença \\
Alface inteira & 7,0 & 9,9 & $-2,9$ & & & \\
Repolho Inteiro & 15,4 & 4,9 & 10,5 & 4,9 & 8,7 & $-3,8$ \\
Rabanete & 1,6 & 13,0 & $-11,4$ & 11,6 & 4,4 & 7,2 \\
Tomate & 1,7 & $-0,8$ & 2,5 & 1,0 & 10,8 & $-9,8$ \\
\multicolumn{1}{c}{ Média } & 6,4 & 6,8 & $-0,3$ & 1,0 & $-0,6$ & 1,6 \\
Alface Fracionada & 12,0 & 17,3 & $-5,3$ & 4,6 & 5,8 & $-1,2$ \\
Repolho Fracionado & 12,8 & 27,7 & $-14,9$ & & & \\
$\quad$ Média & 12,4 & 22,5 & $-10,1$ & 11,4 & 19,8 & $-10,4$ \\
\hline
\end{tabular}


Os dados acima apresentados evidenciam diferenças de comportamento dos sanificantes à base de dicloroisocianurato de sódio e o hipoclorito de sódio, relacionadas ao tipo do vegetal, da mesma forma que Nascimento \& Catanozi (2002) constataram na sanificação de frutas e hortaliças. Além disso, essas diferenças também são evidenciadas nos tratamentos das hortaliças inteiras ou fracionadas.

O maior gasto de cloro livre em soluções de hipoclorito de sódio no tratamento de vegetais fracionados é justificada pela maior liberação de exsudato do vegetal em função do corte, e por sua menor estabilidade em comparação às soluções de dicloroisocianurato de sódio frente à presença de material orgânico (Macedo \& Barra, 2002; Marriott,1985).

As diferenças de consumo de cloro livre entre os vegetais, por sua vez, podem estar ligadas às diferenças em sua composição química, modificação do $\mathrm{pH}$ da solução (ex. ácido ascórbico do tomate) e/ou por liberação de algum elemento mais reativo (ex. enxofre do repolho) (Franco,1987)

Eiroa e Porto (1995), em estudo com alfaces inteiras contaminadas com $V$. cholerae 01 e tratadas com soluções de hipoclorito de sódio a 100 e $200 \mathrm{mg} \mathrm{L}^{-1}$ e de 3 diferentes formulações à base de dicloroisocianurato de sódio a $100 \mathrm{mg} \mathrm{L}^{-1}$, por um período de contado de 15 minutos, em dois usos da solução, demonstraram que a presença de material orgânico não afetou de forma significativa a eficiência da solução de $2^{\circ}$ uso, cuja redução de cloro ativo foi de $8 \%$, abaixo das verificadas neste estudo de $10,1 \%$ (I) e $28,1 \%$ (F) para o NaDCC e $11,6 \%$ (I) e 50,5\% (F) para o NaOCl, após 3 usos das soluções.

A opção pela forma de sanificação das hortaliças folhosas, inteiras ou fracionadas, é facultada a cada serviço. Quando às condições ambientais, oferecem risco de contaminação do produto durante a etapa do fracionamento, é recomendável que a hortaliça seja fracionada antes da desinfecção. Neste caso, devem ser utilizadas facas ou lâminas devidamente afiadas, de forma que o corte danifique o mínimo possível o tecido vegetal, levando a uma menor liberação de sucos vegetais, e à menor perda de cloro livre (Wiley, 1997; Marriott, 1985). 


\subsection{2 $\mathrm{pH}$}

O pH médio inicial das soluções cloradas foi de 6,9 para NaDCC e de $\mathbf{8 , 9}$ para o $\mathrm{NaOCl}$, conforme se observa na Tabela 10.

Em geral, as soluções de ambos os sanificantes apresentaram redução de pH, acidificando-se à medida em que foram sendo utilizadas e reutilizadas.

Após o $1^{\circ}$ uso, o pH médio entre todas as soluções vegetais de $\mathrm{NaDCC}$ e $\mathrm{NaOCl}$ foi, respectivamente, para os vegetais inteiros de 6,95 e 9,00; para os fracionados de 6,75 e 8,20 . Após o $2^{\circ}$ uso, para os vegetais inteiros de 6,8 e 8,75 ; para os fracionados de 6,70 e 7,8. Após o $3^{\circ}$ uso, para os vegetais inteiros de 6,58 e 8,68; e para os fracionados de 6,50 e 7,45 (Tabela 7).

Tabela 10. Média de pH em soluções iniciais de $\mathrm{NaDCC}$ e $\mathrm{NaOCl}$

\begin{tabular}{ccc}
\hline Soluções & NaD C C & N aOCl \\
\hline 1 & 6,8 & 8,8 \\
2 & 6,9 & 8,8 \\
3 & 6,9 & 8,6 \\
4 & 6,8 & 8,8 \\
5 & $\mathrm{~N} \mathrm{R}$ & 8,9 \\
6 & 7,2 & 9,5 \\
Média & $6,9 \pm 0,2$ & $8,9 \pm 0,3$ \\
\hline
\end{tabular}

As reduções médias de $\mathrm{pH}$ ao final do $3^{\circ}$ uso nas soluções de $\mathrm{NaDCC}$ e $\mathrm{NaOCl}$ no tratamento de cada vegetal foram, respectivamente, para os inteiros de $0,4 \mathrm{e}$ 0,4 (al), 0,8 e 0,2 (rp), 0,3 e 0,7 (rb), 0,4 (após dois usos) e -0,2 (to); nos vegetais fracionados de 0,3 e 0,9 (al) e 0,4 e 1,8 (rp), conforme se verifica na Tabela 11. As médias entre as reduções de pH verificadas para cada uma das soluções, após o terceiro uso, para o $\mathrm{NaDCC}$ e $\mathrm{NaOCl}$ foram, respectivamente, para os vegetais inteiros de 0,48 e 0,28 ; para os fracionados de 0,35 e 1,35 (Tabela 11). 
A efetividade das soluções cloradas é afetada pelo pH, ideal a 7,4 e 7,6, ou menor, quando a presença do ácido hipocloroso é dominante (Macedo, 2002; Oliveira \& Valle, 2000; Marriott, 1985).

Eiroa e Porto (1995) justificam a menor eficácia de soluções de hipoclorito de sódio a 100 e $200 \mathrm{mg} \mathrm{L}^{-1}$ em relação a soluções de dicloroisocianurato de sódio a 100 $\mathrm{mg} \mathrm{L}^{-1}$ na redução do $V$. cholerae inoculado em folhas de alfaces devido ao $\mathrm{pH}$ das soluções de hipoclorito (pH 9,0), o que levaria à dissociação do ácido hipocloroso e à menor eficácia da solução.

Tabela 11. Médias da evolução do pH de NaDCC em hortaliças

\begin{tabular}{lccccc}
\hline & \multicolumn{5}{c}{$\mathrm{pH}-\mathrm{NaDCC}$} \\
\hline & Inicial & $1^{\circ}$ uso & $2^{\circ}$ uso & $3^{\circ}$ uso & Redução \\
& & & & & \\
Alface inteira & 6,8 & 6,70 & 6,70 & 6,40 & 0,40 \\
Repolho Inteiro & 6,9 & 6,70 & 6,60 & 6,10 & 0,80 \\
Rabanete & 7,2 & 7,10 & 7,00 & 6,90 & 0,30 \\
Tomate & $\mathrm{NR}$ & 7,30 & 6,90 & 6,90 & 0,40 \\
$\quad$ Média & 6,97 & 6,95 & 6,80 & 6,58 & 0,48 \\
$\quad$ & & & & & \\
Alface Fracionada & 6,9 & 6,80 & 6,70 & 6,60 & 0,30 \\
Repolho Fracionado & 6,8 & 6,70 & 6,70 & 6,40 & 0,40 \\
$\quad$ Média & 6,85 & 6,75 & 6,70 & 6,50 & 0,35 \\
\hline
\end{tabular}

NR - Não realizado

As maiores reduções acumuladas de $\mathrm{pH}$ foram para as soluções de hipoclorito em vegetais fracionados, especialmente para o repolho (Tabela 12). Também, foram as soluções de hipoclorito de sódio na sanificação do repolho que mais acumularam perda de cloro livre. Assim, pode-se especular que a redução de pH verificada nestas soluções tem a possibilidade, eventualmente, de vir a compensar a maior perda de cloro livre ao 
longo das reutilizações, pelo favorecimento da formação do ácido hipocloroso em solução (Pinto \& Rohring, 2003; Macedo, 2002).

Tabela 12. Médias da evolução do $\mathrm{pH}$ de $\mathrm{NaOCl}$ em hortaliças

\begin{tabular}{lccccc}
\hline & \multicolumn{5}{c}{$\mathrm{pH}-\mathrm{NaOCl}$} \\
\hline & Inicial & $1^{\circ}$ uso & $2^{\circ}$ uso & $3^{\circ}$ uso & Redução \\
& & & & & \\
Alface inteira & 8,80 & 8,80 & 8,60 & 8,40 & 0,40 \\
Repolho Inteiro & 8,60 & 8,60 & 8,70 & 8,40 & 0,20 \\
Rabanete & 9,50 & 9,70 & 9,00 & 8,80 & 0,70 \\
Tomate & 8,90 & 8,90 & 8,70 & 9,10 & $-0,20$ \\
$\quad$ Média & 8,95 & 9,00 & 8,75 & 8,68 & 0,28 \\
$\quad$ & & & & \\
Alface Fracionada & 8,80 & 8,20 & 8,10 & 7,90 & 0,90 \\
Repolho Fracionado & 8,80 & 8,20 & 7,50 & 7,00 & 1,80 \\
$\quad$ Média & 8,80 & 8,20 & 7,80 & 7,45 & 1,35 \\
\hline
\end{tabular}

No entanto, Nguyen-The \& Prunier (1989) destacam o risco da reutilização de soluções cloradas, através de estudo em que soluções pós-sanificação apresentaram contagens bacterianas de $10^{3} \mathrm{UFC} \mathrm{mL}^{-1}$ em solução de sanificação para chicória. Além disso, considerando a redução das contagens microbianas em hortaliças pela lavagem, procedimento que precede a sanificação, de não mais do que 1 ciclo $\log$, o risco de contaminação das hortaliças pode ser real ( Nascimento \& Catanozi,2002).

Assim, considerando que o risco de não se atender à concentração de cloro livre recomendada, em função tanto da rotulagem de produtos sanificantes (como a exemplo do que foi constatado neste estudo; o teor de cloro ativo do hipoclorito de sódio esteve bem abaixo do referido pelo fabricante), quanto do não atendimento à dosagem indicada pelo fabricante por quem a realiza, somado à redução de cloro livre na reutilização das soluções, a afirmação de Nguyen-The \& Prunier (1999) torna-se um alerta importante. 


\subsubsection{Cloro livre e pH em soluções de hipoclorito de sódio sob condições habituais de processamento na produção de saladas cruas}

As soluções de $\mathrm{NaOCl}$ no tratamento de hortaliças inteiras e fracionadas foram avaliadas após 3 horas de exposição à temperatura, luminosidade ambiente e ao procedimento de sanificação em si.

As soluções utilizadas nos tratamentos tiveram reduções médias percentuais de cloro livre para os vegetais inteiros de $1,7 \%$ (rp) e $-12,7 \%(r b), 2,8 \%$ (to); enquanto para o fracionado, de 28,7 (Tabela 13).

Por sua vez, as reduções médias absolutas de $\mathrm{pH}$ para as soluções dos vegetais inteiros foram de $0,1 \%(\mathrm{rp}),-0,1 \%$ (rb) e $-0,4 \%$ (to), enquanto para o fracionado de $-0,4 \%(\mathrm{rp})$ (Tabela 13).

A redução de cloro ativo nas soluções sanificantes de vegetais inteiros não ultrapassou 3\%. Já nas soluções de tratamento do repolho fracionado, a redução média chegou a $29 \%$ de cloro ativo (Tabela 13 ).

A maior perda de cloro livre das soluções de hipoclorito de sódio no tratamento de vegetais fracionados justifica-se pela maior liberação de exsudato, que somada às condições de temperatura e luminosidade ambiental, propiciou a maior perda de cloro ativo em relação às soluções dos vegetais inteiros.

A diferença de cloro livre nas soluções de rabanete, é justificada por questões metodológicas já que o desvio padrão verificado para esta determinação foi de $\pm 16,3$ (Anexo 1) donde se conclui que, neste caso, não houve consumo de cloro.

Diferentemente do período da sanificação em que as soluções sofreram reduções do $\mathrm{pH}$, e conseqüentemente tornaram-se mais ácidas, as soluções de hipoclorito de sódio remanescentes de 3 horas a condições ambientais, em geral, tiveram elevação do $\mathrm{pH}$, alcalinizando-se um pouco: 0,4 . 
Tabela 13. Reduções médias de $\mathrm{Cl}_{2} \mathrm{mg} \mathrm{L}^{-1}$ e $\mathrm{pH}$ em soluções $\mathrm{NaOCl}$ após a exposição às condições ambientais e de sanificação das hortaliças

\begin{tabular}{lcccc}
\hline & \multicolumn{2}{c}{$\mathrm{NaOCl} \mathrm{mg} \mathrm{L}-1^{-1}$} & \multicolumn{2}{c}{$\mathrm{NaOCl}$ mg L-1 } \\
\hline & $\mathrm{mg} \mathrm{L}$ & $\%$ & $\mathrm{pH}$ & $\%$ \\
Alface inteira & $\mathrm{NR}$ & $\mathrm{NR}$ & $\mathrm{NR}$ & $\mathrm{NR}$ \\
Alface Fracionada & $\mathrm{NR}$ & $\mathrm{NR}$ & $\mathrm{NR}$ & $\mathrm{NR}$ \\
Repolho Inteiro & 1,8 & 1,7 & 0,1 & 1,2 \\
Repolho Fracionado & 14,0 & 28,7 & $-0,4$ & $-5,7$ \\
Rabanete & $-13,7$ & $-12,7$ & $-0,1$ & $-1,1$ \\
Tomate & 3,7 & 2,8 & $-0,4$ & $-4,4$ \\
\hline
\end{tabular}

NR - Não realizado

Assim, principalmente na sanificação de vegetais fracionados, novas reutilizações de soluções de hipoclorito de sódio, durante ou posterior ao período de 3 horas, podem ter sua eficiência diminuída, devido tanto à associação da redução do cloro livre quanto à possibilidade de elevação do pH da solução.

Não pode ser esquecido que um dos critérios práticos para o descarte das soluções sanificantes é a presença de turbidez. Em geral, o repolho é um dos vegetais que, devido a sua estrutura fechada e uso da porção mais tenra, menos verde, em saladas cruas, passa pouca sujidade e não escurece a solução utilizada (pigmento claro), resultando em ausência de turbidez. Logo, a formação de turbidez como um critério de controle pode levar ao uso de soluções com baixa eficiência sanificante, visto a perda de cloro livre verificada no exemplo do repolho, principalmente em se tratando do produto fracionado.

Outro fato a destacar é o critério legal da norma técnica $\operatorname{CVS~} \mathrm{n}^{\circ} 6$, a respeito da indicação de troca da solução sanificante em hortaliças a cada 24 horas, o que devido tanto às reduções de cloro livre verificadas neste estudo, quanto às condições 
ambientais as quais ficam expostas, pode levar ao uso de soluções ineficazes quanto ao propósito da sanificação (São Paulo, 1999).

\subsubsection{Sujidades em soluções pós-sanificação}

Após o terceiro uso, todas as soluções de tratamento dos vegetais avaliados permaneceram límpidas. $\mathrm{O}$ teor médio de sujidades filtradas das soluções da alface foi de $0,029 \mathrm{~g}$ para a inteira (I) e $0,042 \mathrm{~g}$ para a fracionada (F) de um total de $570 \mathrm{~g}$ de vegetal sanificado em três etapas de uso subseqüentes (Tabela 14). A maior quantidade de sujidades do produto fracionado foi devido a uma maior quantidade de restos do vegetal que ficaram em suspensão em relação à do vegetal inteiro. Sendo assim, a relação de $0,05 \mathrm{mg}$ (I) e $0,071 \mathrm{mg}(\mathrm{F})$, para cada grama de alface sanificada, justifica em parte, o aspecto não turvo desta solução. As demais soluções não foram consideradas, devido à inconsistência dos dados (Tabela 14).

Tabela 14. Sujidades pós sanificação em vegetais inteiros e fracionados

\begin{tabular}{lc}
\hline & mg sujidades \\
\hline Alface Interia & $29 \pm 3^{1}$ \\
Alface Fatiada & $42 \pm 1$ \\
Repolho inteiro & $322 \pm 573$ \\
Repolho Fatiado & $329 \pm 91$ \\
\hline
\end{tabular}

${ }^{1}$ Desvio padrão

\subsubsection{Custo-benefício do uso dos sanificantes a $\mathrm{NaOCI}$ e $\mathrm{NaDCC}$}

O percentual de redução de cloro livre para as soluções de NaDCC a $200 \mathrm{mg}$ $\mathrm{Cl}_{2} \mathrm{~L}^{-1}$, após o terceiro uso nos 4 vegetais inteiros, foi de 7,9\%, enquanto nos 2 vegetais fracionados foi de $21,2 \%$. Por sua vez, a média de redução percentual de cloro livre 
após o terceiro uso para as soluções de $\mathrm{NaOCl}$ a $200 \mathrm{mg} \mathrm{Cl}_{2} \mathrm{~L}^{-1}$ nos 4 vegetais inteiros foi de 7,4\%, enquanto nos 2 vegetais fracionados foi de $30 \%$ (Tabela 15 e 16).

Tabela 15. Estimativa de consumo de cloro livre em soluções de $\mathrm{NaOCl}$ e $\mathrm{NaDCC}$ a 200 $\mathrm{Cl}_{2} \mathrm{mgL}^{-1}$ após terceiro em hortaliças

\begin{tabular}{lcccc}
\hline & \multicolumn{2}{c}{$\mathrm{NaDCC}$} & \multicolumn{2}{c}{$\mathrm{NaOCl}$} \\
\hline & $\mathrm{Cl}_{2} \mathrm{~L}^{-1}$ & $\%$ & $\mathrm{Cl}_{2} \mathrm{~L}^{-1}$ & $\%$ \\
Alface Inteira & & & & \\
Repolho Inteiro & 16,3 & 8,2 & 23,6 & 11,8 \\
Tomate & 26,2 & 13,1 & 20,5 & 10,3 \\
Rabanete & 5,5 & 2,8 & $-3,9$ & $-2,0$ \\
$\quad$ Média & 14,8 & 7,4 & 19,0 & 9,5 \\
$\quad 24,6$ & 7,9 & 14,8 & 7,4 \\
Alface Fracionada & 38,5 & 19,3 & 53,0 & 26,5 \\
Repolho Fracionado & 46,4 & 23,2 & 67,0 & 33,5 \\
$\quad$ Média & 42,5 & 21,2 & 60,0 & 30,0 \\
\hline
\end{tabular}

Tabela 16. Soluções remanescentes de $\mathrm{NaOCl}$ e $\mathrm{NaDCC}$ a $200 \mathrm{Cl}_{2} \mathrm{mgL}^{-1}$ após terceiro em hortaliças

$\mathrm{NaDCC} \quad \mathrm{NaOCl}$

\begin{tabular}{|c|c|c|}
\hline Alface Inteira & 183,7 & 176,4 \\
\hline Repolho Inteiro & 173,8 & 179,5 \\
\hline Tomate & 194,5 & 203,9 \\
\hline Rabanete & 185,2 & 181,0 \\
\hline Média & 175,4 & 185,2 \\
\hline Alface Fracionada & 161,5 & 147,0 \\
\hline Repolho Fracionado & 153,6 & 133,0 \\
\hline Média & 157,6 & 140,0 \\
\hline
\end{tabular}


Visto apenas em termos de cloro livre, todas as soluções seriam passíveis de nova(s) reutilização(ões), já que ficaram acima de $100 \mathrm{mg} \mathrm{Cl}_{2} \mathrm{~L}^{-1}$, com margens médias maiores de cloro livre para as soluções de vegetais não fracionados.

O custo por litro de solução a $200 \mathrm{mg} \mathrm{Cl}_{2} \mathrm{~L}^{-1}$ a partir do $\mathrm{NaOCl}$ variou entre $R \$ 0,009 \mathrm{~L}^{-1}$ a $\mathrm{R} \$ 0,034 \mathrm{~L}^{-1}$, enquanto para o NaDCC foi de $\mathrm{R} \$ 0,034$ a $R \$ 0,042 \mathrm{~L}^{-1}$ (Tabela 17 e 18).

Tabela 17. Custo de sanificantes clorados solução de $200 \mathrm{mg} \mathrm{Cl}_{2} \mathrm{~L}^{-1}$

\begin{tabular}{lcc}
\hline Sanitizante & $\mathrm{mL}^{-1}$ ou $\mathrm{g} \mathrm{L}^{-1}$ & $\mathrm{R} \$$ \\
\hline Hipoclorito de sódio 2 a 2,5\% ${ }^{\mathrm{a}}$ & 8,9 & 0,009 \\
Hipoclorito de sódio $4 \%$ a $6 \%^{\mathrm{b}}$ & 4,0 & 0,034 \\
Dicloroisocianurato de sódio 8,7\% Min. & 2,3 & 0,034 \\
Dicloroisocianurato de sódio 2,5\% Min. & 8,0 & 0,042 \\
\hline
\end{tabular}

a Cândida 2,0 a 2,5 \% - Indústria Anhembi S/A, Osasco -SP; Cotação: Frasco de 2 litros $=R \$ 2,00$

b Hipoclorito P.A. 4 a 6\% - Synth; Cotação: Frasco de 1 litro $=$ R $\$ 8,58$

c Saniverd 8\% - Econ Indústria e Comércio de Produtos de Higiene e Limpeza Ltda, Guarulhos-SP; Cotação: Galão de 5 litros $=\mathrm{R} \$ 42,90$

d Mikro chlor 2,5\% - ECOLAB Química LTDA, Rio de Janeiro - RJ;

Balde $5,00 \mathrm{Kg}=\mathrm{R} \$ 26,00$

a, b, c, d Cotações feitas em 02.06.2004 (US\$ 3,20)

Assim, a variação percentual de custo foi de 0 a $79 \%$ a mais para o $\mathrm{NaDCC}$ em relação à solução de $\mathrm{NaOCl}$ (Tabela 19).

Avaliando apenas pelo ponto de vista de rendimento e custo, considerando três usos das soluções, a opção pelo $\mathrm{NaOCl}$ pode ser mais vantajosa, dependendo da cotação feita e o percentual de cloro ativo do produto. A diferença percentual de até 
$79 \%$ a menos no custo do $\mathrm{NaOCl}$ em relação ao $\mathrm{NaDCC}$ compensaria, inclusive, o maior consumo de cloro ativo do $\mathrm{NaOCl}$ em hortaliças fracionados, em torno de $18 \%$, após 3 usos da solução.

Tabela 18. Custo por litro de solução de $\mathrm{NaOCl}$ e NaDCC a $200 \mathrm{mg} \mathrm{Cl} \mathrm{Cl}_{2}^{-1}$

\begin{tabular}{ccc}
\hline & \multicolumn{2}{c}{$\mathrm{R} \$$ por Litro } \\
\hline Cotação & $\mathrm{NaDCC}$ & $\mathrm{NaOCl}$ \\
& & \\
1 & 0,034 & 0,009 \\
2 & 0,042 & 0,034 \\
\hline
\end{tabular}

Tabela 19. Diferença percentual entre a relação de custo por litro das soluções sanificantes a base de $\mathrm{NaOCl}$ e $\mathrm{NaDCC}$ a $200 \mathrm{mg} \mathrm{Cl}_{2} \mathrm{~L}^{-1}$

\section{Diferença \%}

\begin{tabular}{|c|c|}
\hline Hipoclorito $^{1 / \text { Dicloro }^{1}}$ & 74 \\
\hline Hipoclorito $^{2} /$ Dicloro ${ }^{1}$ & 0 \\
\hline Hipoclorito ${ }^{1 / D i c l o r o}{ }^{2}$ & \\
\hline Hipoclorito $^{2} /$ Dicloro $^{2}$ & 1 \\
\hline
\end{tabular}

${ }^{1}$ Cotação 1

${ }^{2}$ Cotação 2

A ação sanificante é depende do pH da solução, mais elevadas nas soluções $\mathrm{NaOCl}$. Assim, o uso de soluções de $\mathrm{NaOCl}$ necessitariam de correção do $\mathrm{pH}$ para 7,00 (ácidos orgânicos, tampão fosfato $\mathrm{pH} 7,0$ ) aumentando sua efetividade microbicida, tornando-se uma boa opção em termos de custo-beneficio (Macedo,2002, Macedo \& Barra,2002, Eiroa \& Porto, 1995). 


\section{CONCLUSÕES}

Nas condições deste estudo verificou-se que:

1) tanto as amostras de hortaliças in natura quanto as saladas prontas estiveram dentro dos padrões microbiológicos previstos pela legislação;

2) a lavagem em água corrente reduziu as contagens bacterianas nas hortaliças. No caso da alface, a redução foi de 1,46 ciclos log para mesófilos totais e E. coli reduzida abaixo do limite de detecção;

3) não houve diferenças nas reduções bacterianas obtidas entre o início e o final do processo de sanificação. O tratamento com cloro reduziu as contagens de mesófilos na alface em 0,66 ciclos $\log$ e 0,12 ciclos para E. coli; o tratamento adicional com vinagre agrin acrescentou redução de 0,35 ciclos log somente na população de mesófilos. $O$ processo completo reduziu a população de mesófilos em 1,0 ciclo log e E coli em 0,12 ciclo log., sendo satisfatório nessas condições.

4) o kit dosador de cloro livre por faixas calorimétricas foi ineficiente, identificando o ponto crítico de controle abaixo de $100 \mathrm{Cl}_{2} \mathrm{mg} \mathrm{L}^{-1}$ em $21 \%$ das amostras analisadas, enquanto o método titulométrico identificou 67\%. Em 8 de 14 análises o teor de cloro esteve abaixo do ponto crítico.

5) soluções formuladas a partir dos dados de rotulagem geraram soluções de hipoclorito de sódio em média $40 \%$ abaixo do valor pretendido para as soluções de sanificação, e para o diclorosocianurato de sódio em média $19 \%$ maiores. A 
titulação inicial de uma solução clorada é o primeiro passo para a garantia de um procedimento de sanificação;

6) a média de perda de cloro livre nas soluções sanificantes das 4 hortaliças avaliadas foi para o hipoclorito de sódio de 11,6 para os vegetais inteiros e $50,5 \%$ para as hortaliças fracionadas; para o dicloroisocianurato de sódio de $10, \% 1$ para os vegetais inteiros e $28,1 \%$ para as hortaliças fracionadas;

7) as soluções de hipoclorito de sódio apresentaram reduções médias de $\mathrm{pH}$, ao final do $3^{\circ}$ uso, de 0,48 nos vegetais inteiros e 0,35 nos vegetais fracionados; as soluções de dicloroisocianurato de sódio apresentaram reduções médias de $\mathrm{pH}$, ao final do $3^{\circ}$ uso, de 0,28 nos vegetais inteiros e 1,35 nos vegetais fracionados. Os vegetais fracionados alteraram mais o $\mathrm{pH}$ das soluções;

8) o repolho fracionado foi o produto que mais acumulou perda de cloro ativo: $31,2 \%$ para hipoclorito de $\mathrm{Na}$ e $57,9 \%$ para o dicloroisocianurato de $\mathrm{Na}$ e maior redução de $\mathrm{pH}(1,8)$ durante o processo de sanificação;

9) soluções remanescentes de hipoclorito de sódio no tratamento de hortaliças expostas a condições ambientais de luminosidade e temperatura,por período de 3 horas, a partir do procedimento de sanificação, apresentaram reduções médias de cloro livre de $3 \%$ em hortaliças inteiras e $29 \%$ no repolho fracionado;

10) as soluções remanescentes do tratamento da alface inteira e fracionada acumularam, após o $3^{\circ}$ uso de suas soluções, $0,05 \mathrm{mg}$ e $0,071 \mathrm{mg}$ de sujidades em solução;

11) em termos de rendimento e custo o hipoclorito de sódio foi até $79 \%$ mais barato do que o dicloroisocianurato de sódio. 
ANEXOS 


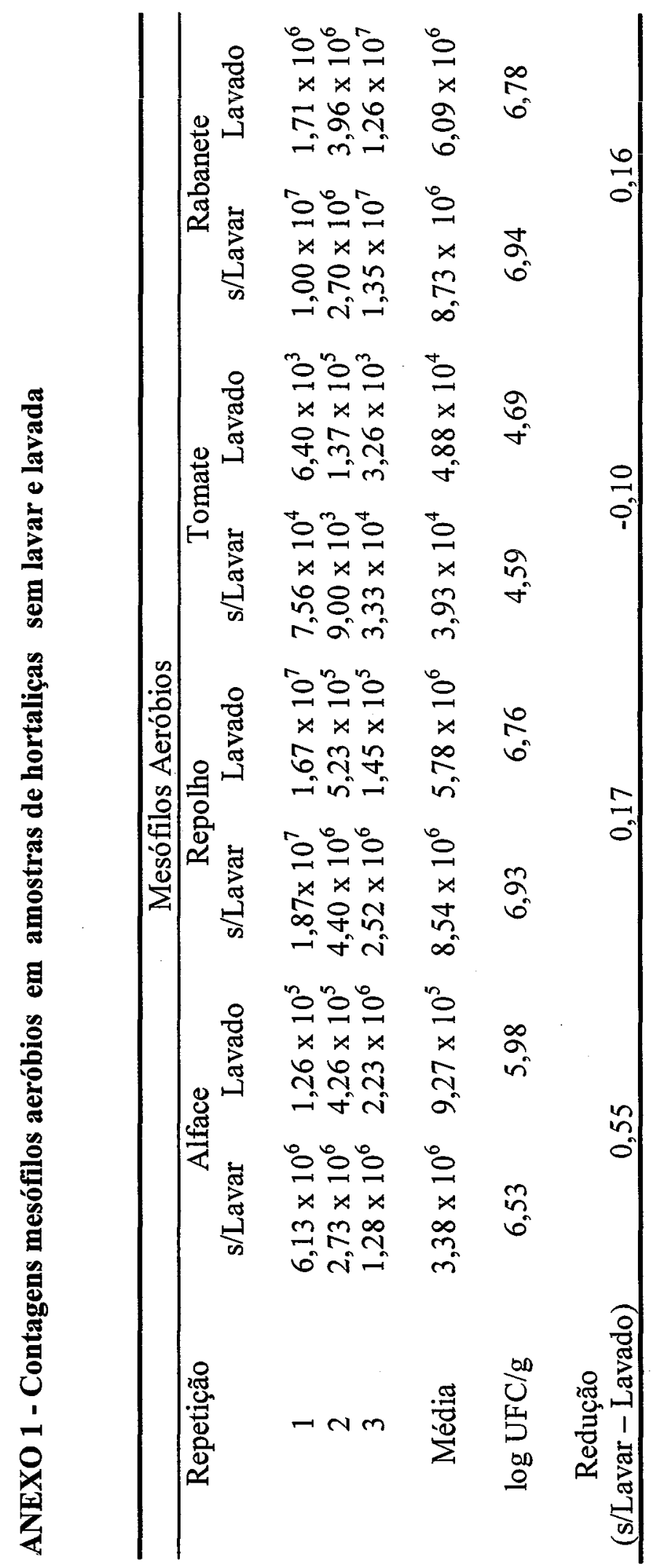




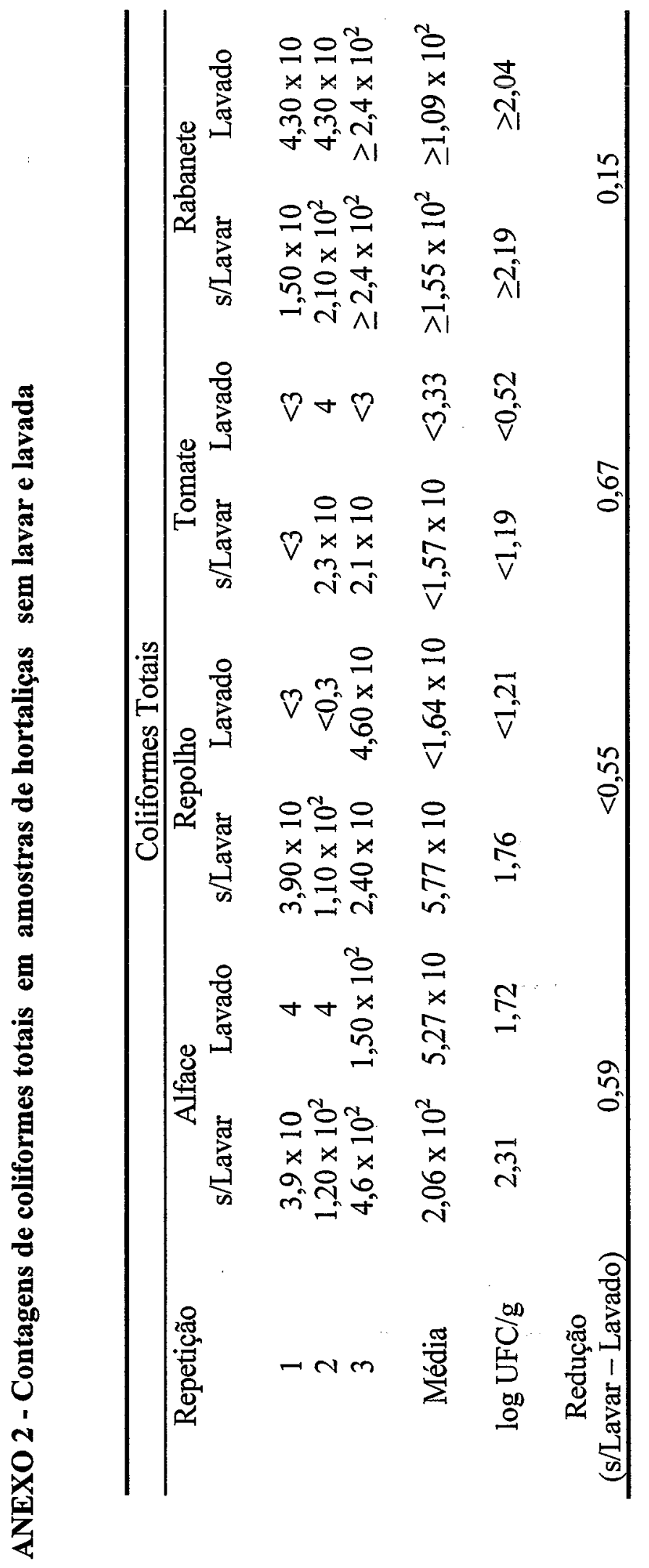




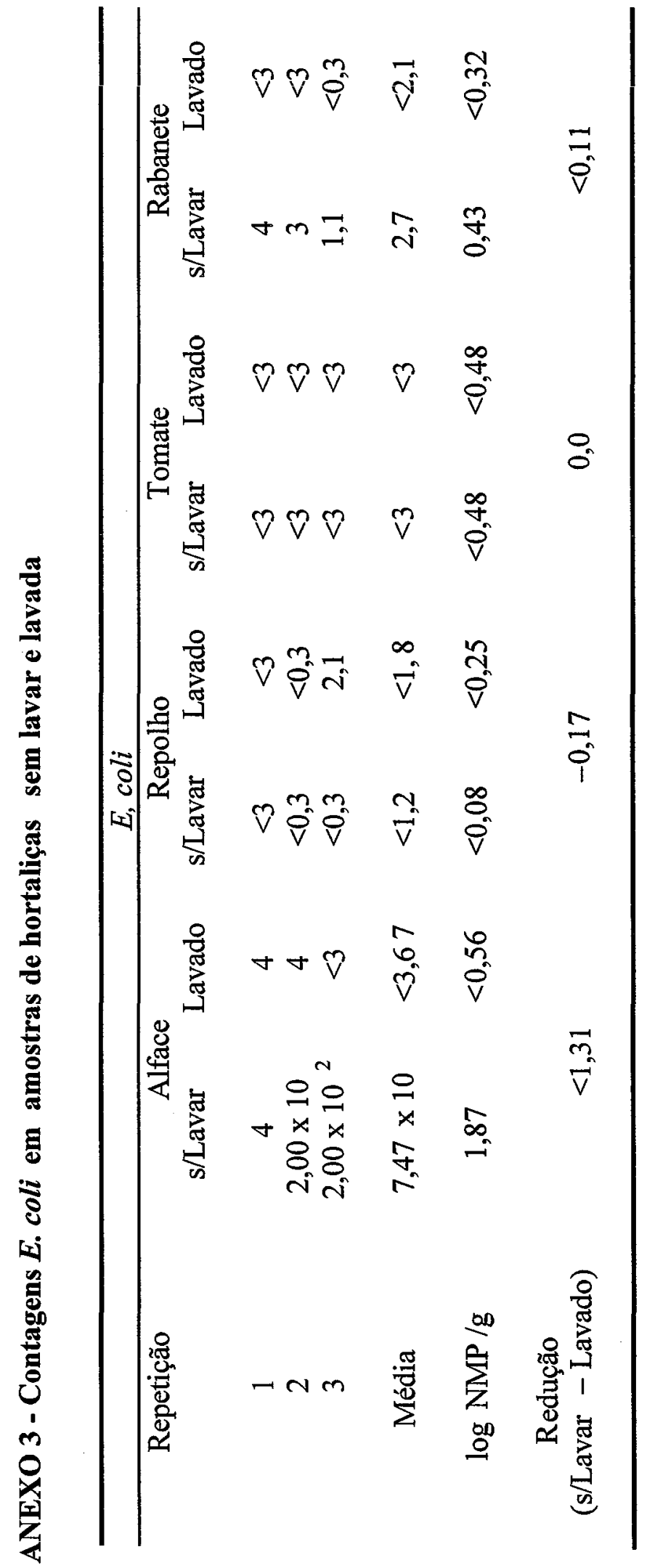




\section{ANEXO 4 - Contagens de mesófilos aeróbios em alface lavada, sanificada e lavada com vinagre}

\begin{tabular}{|c|c|c|c|c|c|c|}
\hline \multicolumn{7}{|c|}{ Mesófilos Aeróbios } \\
\hline & \multicolumn{3}{|c|}{ Caixa inicial } & \multicolumn{3}{|c|}{ Caixa final } \\
\hline Repetição & $\begin{array}{l}\text { Lavada } \\
\text { (L) }\end{array}$ & $\begin{array}{l}\text { Clorada } \\
\text { (C) }\end{array}$ & $\begin{array}{l}\text { Vinagre } \\
\text { (V) }\end{array}$ & $\begin{array}{l}\text { Lavada } \\
\text { (L) }\end{array}$ & $\begin{array}{l}\text { Clorada } \\
\text { (C) }\end{array}$ & $\begin{array}{l}\text { Vinagre } \\
\text { (V) }\end{array}$ \\
\hline 1 & $1,09 \times 10^{6}$ & $3,86 \times 10^{6}$ & NR & NR & NR & NR \\
\hline 2 & $1,79 \times 10^{6}$ & $9,3 \times 10^{5}$ & $2,66 \times 10^{5}$ & NR & $4,44 \times 10^{5}$ & $7,03 \times 10^{5}$ \\
\hline 3 & $4,8 \times 10^{6}$ & $4,1 \times 10^{5}$ & $1,79 \times 10^{5}$ & $4,9 \times 10^{6}$ & $4,22 \times 10^{5}$ & $4,9 \times 10^{5}$ \\
\hline 4 & NR & NR & $4,6 \times 10^{4}$ & $5,3 \times 10^{5}$ & $1,24 \times 10^{6}$ & $9 \times 10^{4}$ \\
\hline 5 & $3,6 \times 10^{6}$ & $2,01 \times 10^{5}$ & $8,66 \times 10^{4}$ & $1,07 \times 10^{6}$ & $7,36 \times 10^{5}$ & $1,16 \times 10^{5}$ \\
\hline 6 & $4,56 \times 10^{5}$ & $4,53 \times 10^{5}$ & $1,06 \times 10^{5}$ & $1,34 \times 10^{6}$ & $4,26 \times 10^{5}$ & $2,06 \times 10^{5}$ \\
\hline 7 & $3,0 \times 10^{6}$ & $2,73 \times 10^{6}$ & $9,0 \times 10^{5}$ & NR & $3,76 \times 10^{5}$ & $1,01 \times 10^{6}$ \\
\hline 8 & $1,19 \times 10^{6}$ & $1,81 \times 10^{5}$ & $3,3 \times 10^{5}$ & $9,5 \times 10^{5}$ & $5,23 \times 10^{5}$ & $5,4 \times 10^{5}$ \\
\hline 9 & $3,03 \times 10^{5}$ & $6,9 \times 10^{5}$ & NR & $4,36 \times 10^{5}$ & $4,03 \times 10^{5}$ & NR \\
\hline 10 & $3,36 \times 10^{6}$ & $4,6 \times 10^{5}$ & NR & NR & $2,63 \times 10^{5}$ & NR \\
\hline 11 & $7,86 \times 10^{6}$ & $3,86 \times 10^{5}$ & $1,35 \times 10^{5}$ & $2,8 \times 10^{6}$ & $1,57 \times 10^{6}$ & $5,86 \times 10^{5}$ \\
\hline 12 & $3,86 \times 10^{6}$ & $9,55 \times 10^{5}$ & $9,76 \times 10^{4}$ & $4,8 \times 10^{6}$ & $1,07 \times 10^{6}$ & $2,22 \times 10^{6}$ \\
\hline 13 & $7,9 \times 10^{6}$ & $1,1 \times 10^{6}$ & $6,43 \times 10^{5}$ & $1,11 \times 10^{7}$ & $1,18 \times 10^{6}$ & $5,56 \times 10^{5}$ \\
\hline 14 & $1,4 \times 10^{6}$ & $1,2 \times 10^{5}$ & $1,87 \times 10^{5}$ & $1,94 \times 10^{6}$ & $1,06 \times 10^{5}$ & $4,9 \times 10^{4}$ \\
\hline $\begin{array}{l}\text { Média } \\
\text { UFC/g }\end{array}$ & $3,12 \times 10^{6}$ & $9,60 \times 10^{5}$ & $2,7 \times 10^{5}$ & $2,99 \times 10^{6}$ & $6,74 \times 10^{5}$ & $5,97 \times 10^{5}$ \\
\hline$\underset{\mathrm{UFC} / \mathrm{g}}{\log }$ & 6,49 & 5,98 & 5,43 & 6,47 & 5,83 & 5,77 \\
\hline Redução & & $L-C=0,51$ & & & $L-C=0,64$ & \\
\hline $\log$ & & $C-V=0,55$ & & & $C-V=0,06$ & \\
\hline $\mathrm{UFC} / \mathrm{g}$ & & $\mathrm{L}-\mathrm{V}=1,06$ & & & $\mathrm{~L}-\mathrm{V}=0,7$ & \\
\hline
\end{tabular}

NR - Não realizado 
ANEXO 5 - Contagens coliformes totais em alface lavada, sanificada e lavada com vinagre

\begin{tabular}{|c|c|c|c|c|c|c|}
\hline \multicolumn{7}{|c|}{ Coliformes totais } \\
\hline \multirow[b]{2}{*}{ Repetição } & \multicolumn{3}{|c|}{ Caixa inicial } & \multicolumn{3}{|c|}{ Caixa final } \\
\hline & $\begin{array}{l}\text { Lavada } \\
\text { (L) }\end{array}$ & $\begin{array}{l}\text { Clorada } \\
\text { (C) }\end{array}$ & $\begin{array}{l}\text { Vinagre } \\
\text { (V) }\end{array}$ & $\begin{array}{l}\text { Lavada } \\
\text { (L) }\end{array}$ & $\begin{array}{l}\text { Clorada } \\
\text { (C) }\end{array}$ & $\begin{array}{l}\text { Vinagre } \\
\text { (V) }\end{array}$ \\
\hline 1 & $\geq 2,4 \times 10^{2}$ & 2 & NR & NR & $\geq 2,4 \times 10^{2}$ & NR \\
\hline 2 & $2,4 \times 10$ & $\geq 2,4 \times 10^{2}$ & $\geq 2,4 \times 10^{2}$ & NR & $1,1 \times 10^{2}$ & $1,10 \times 10^{2}$ \\
\hline 3 & $2,4 \times 10$ & $4,6 \times 10$ & $2,4 \times 10$ & $2,1 \times 10$ & 4,3 & $1,10 \times 10^{2}$ \\
\hline 4 & $4,6 \times 10$ & NR & 2,1 & $2,1 \times 10$ & $\geq 2,4 \times 10^{2}$ & $1,5 \times 10$ \\
\hline 5 & $2,4 \times 10$ & 4,3 & 2,1 & $1,1 \times 10^{2}$ & $2,1 \times 10$ & $2,4 \times 10$ \\
\hline 6 & $4,6 \times 10$ & $\geq 2,4 \times 10^{2}$ & $\geq 2,4 \times 10^{2}$ & $1,1 \times 10^{2}$ & $\geq 2,4 \times 10^{2}$ & $\geq 2,4 \times 10^{2}$ \\
\hline 7 & $1,5 \times 10$ & 9,3 & 9,3 & NR & 9,3 & 9,3 \\
\hline 8 & $\geq 2,4 \times 10^{2}$ & $1,5 \times 10$ & 9,3 & $1,1 \times 10^{2}$ & $1,1 \times 10^{2}$ & $4,6 \times 10$ \\
\hline 9 & $2,4 \times 10$ & 4,3 & NR & 9,3 & $2,1 \times 10$ & NR \\
\hline 10 & $\geq 2,4 \times 10^{2}$ & 9,3 & NR & NR & $1,1 \times 10^{2}$ & NR \\
\hline 11 & $\geq 2,4 \times 10^{2}$ & $\geq 2,4 \times 10^{2}$ & $\geq 2,4 \times 10^{2}$ & $\geq 2,4 \times 10^{2}$ & $\geq 2,4 \times 10^{2}$ & $\geq 2,4 \times 10^{2}$ \\
\hline 12 & $4,6 \times 10$ & $4,6 \times 10$ & $1,1 \times 10^{2}$ & $\geq 2,4 \times 10^{2}$ & $\geq 2,4 \times 10^{2}$ & $2,1 \times 10$ \\
\hline 13 & $1,1 \times 10^{2}$ & $1,5 \times 10$ & $\geq 2,4 \times 10^{2}$ & $4,6 \times 10$ & $2,1 \times 10$ & $1,10 \times 10^{2}$ \\
\hline 14 & $\geq 2,4 \times 10^{2}$ & $\geq 2,4 \times 10^{2}$ & $\geq 2,4 \times 10^{2}$ & $\geq 2,4 \times 10^{2}$ & $1,10 \times 10^{2}$ & $\geq 2,4 \times 10^{2}$ \\
\hline Média & $\geq 1,1 \times 10^{2}$ & $\geq 6,55 \times 10$ & $\geq 1,23 \times 10^{2}$ & $\geq 1,45 \times 10^{2}$ & $\geq 1,2 \times 10^{2}$ & $\geq 1,06 \times 10^{2}$ \\
\hline $\log$ & $\geq 2,04$ & $\geq 1,93$ & $\geq 2,09$ & $\geq 2,16$ & $\geq 2,09$ & $\geq 2,02$ \\
\hline Redução & & $L-C=0,11$ & & & $L-C=0,07$ & \\
\hline Log & & $C-V=-0,16$ & & & $C-V=0,07$ & \\
\hline $\mathrm{UFC} / \mathrm{g}$ & & $L-V=-0,05$ & & & $L-V=0,14$ & \\
\hline
\end{tabular}

NR - Não realizado 
ANEXO 6 - Contagens E.coli em alface lavada, sanificada e lavada com vinagre

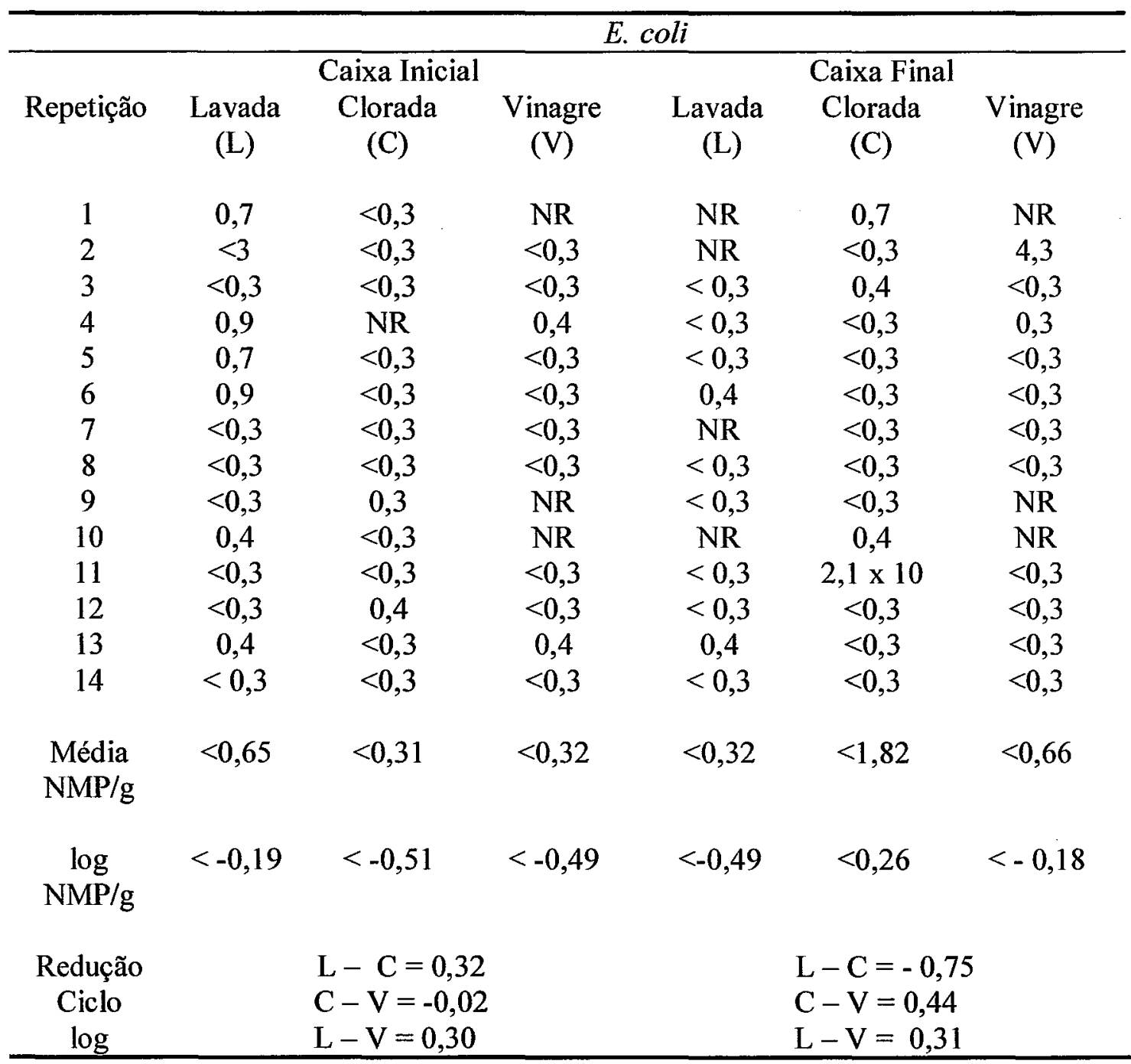

NR - Não realizado 
है
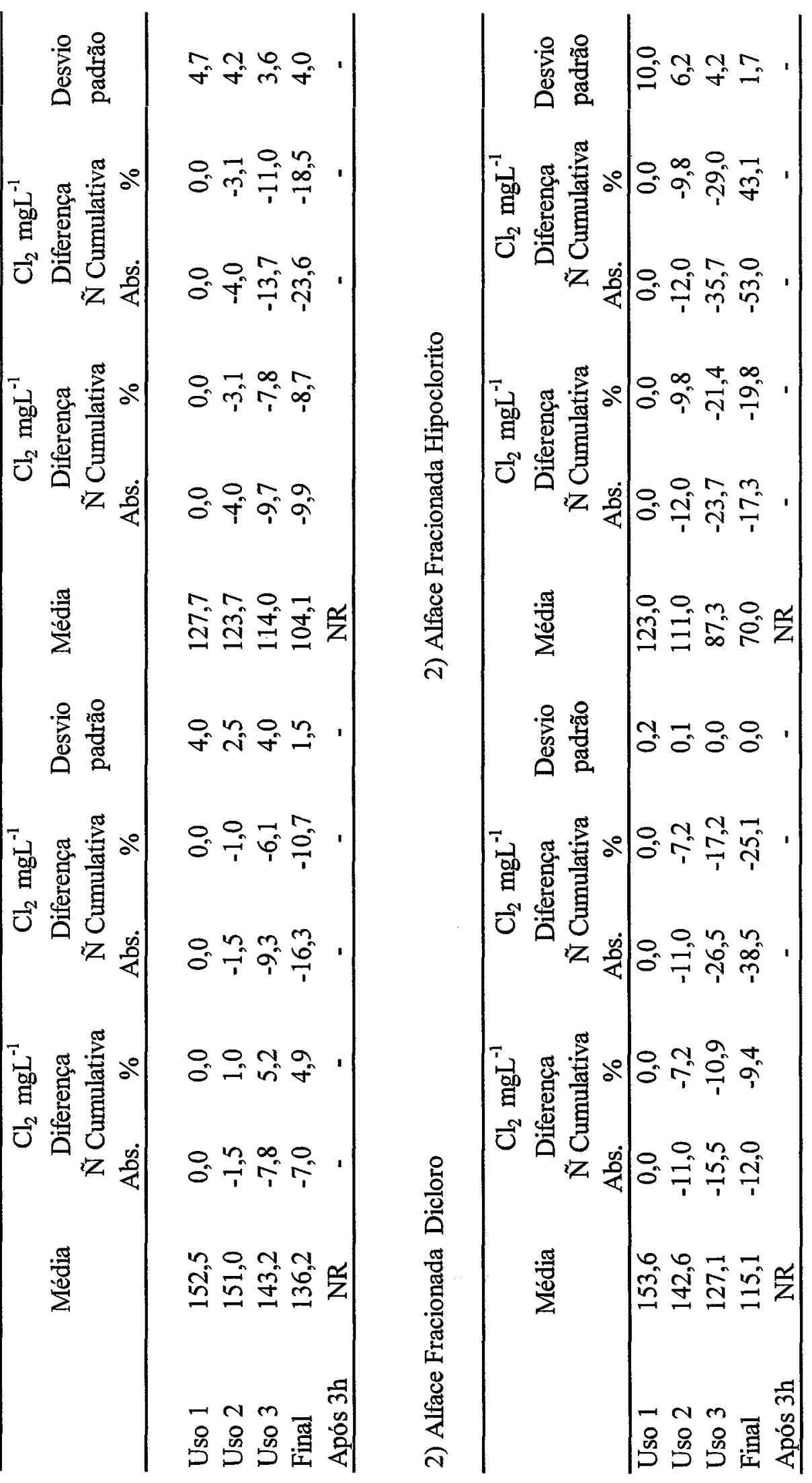


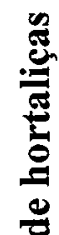

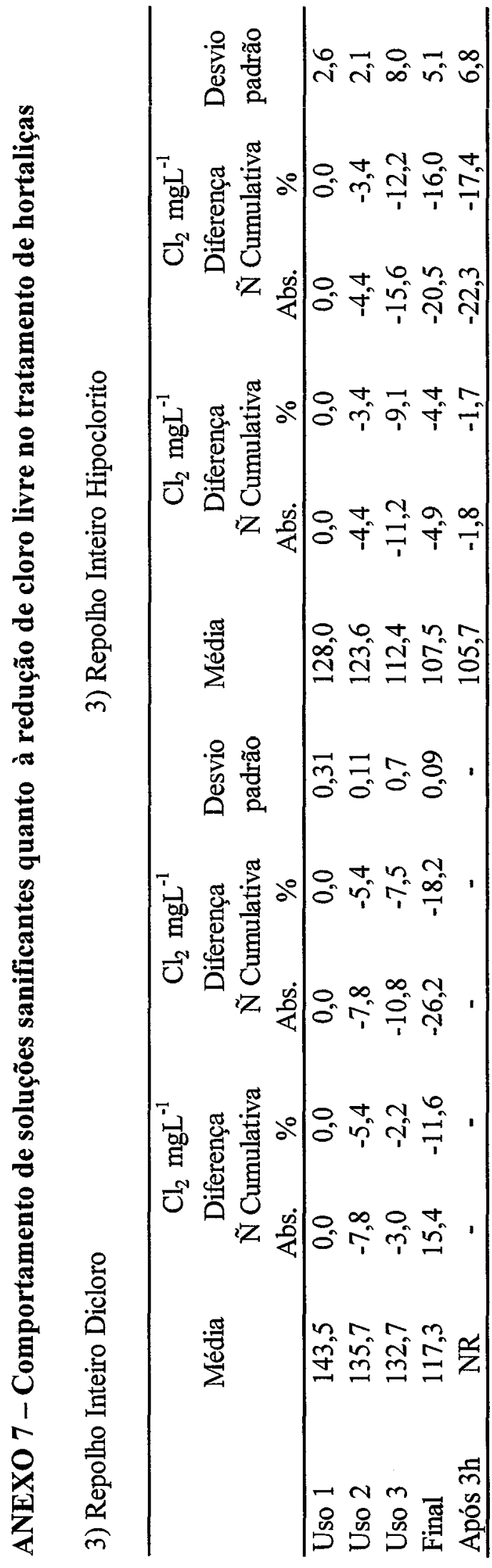

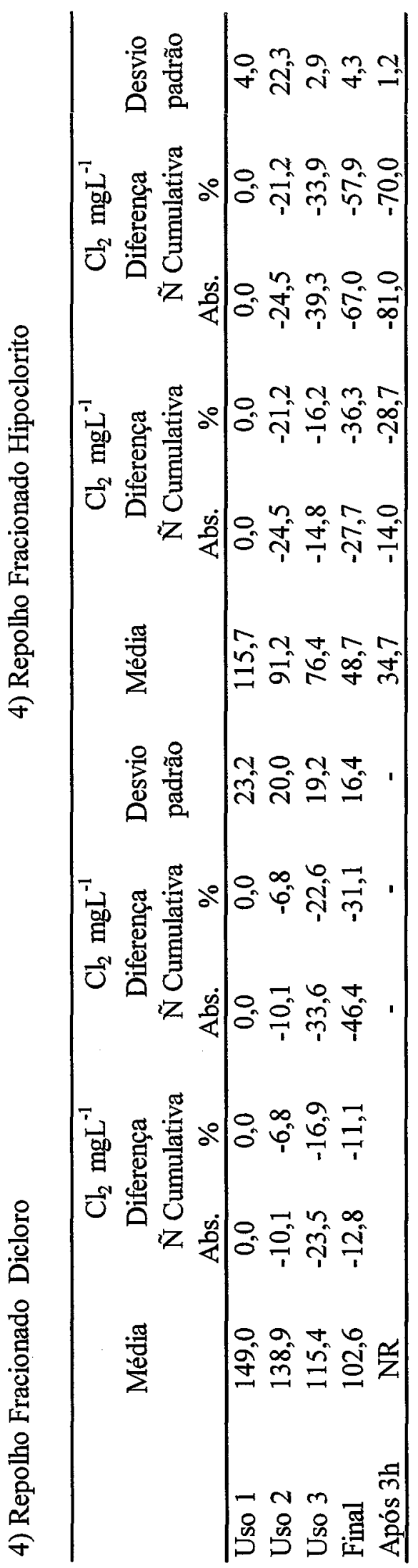


.

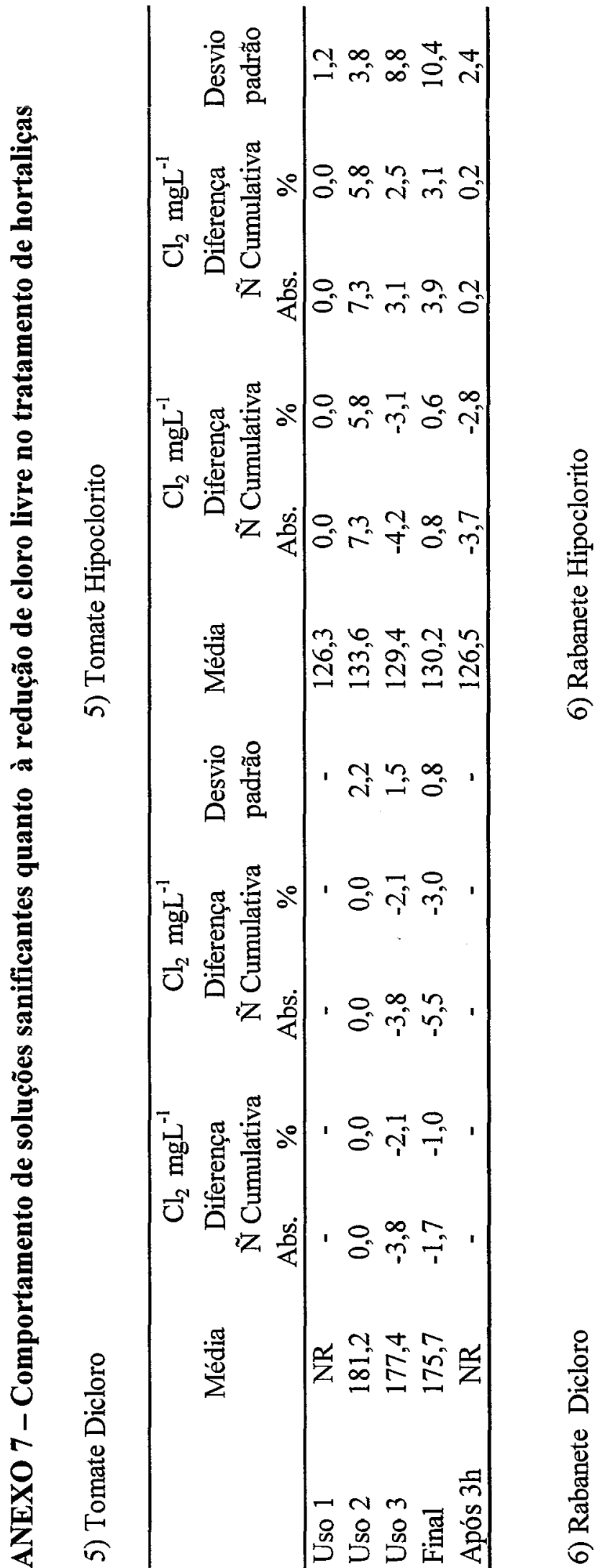

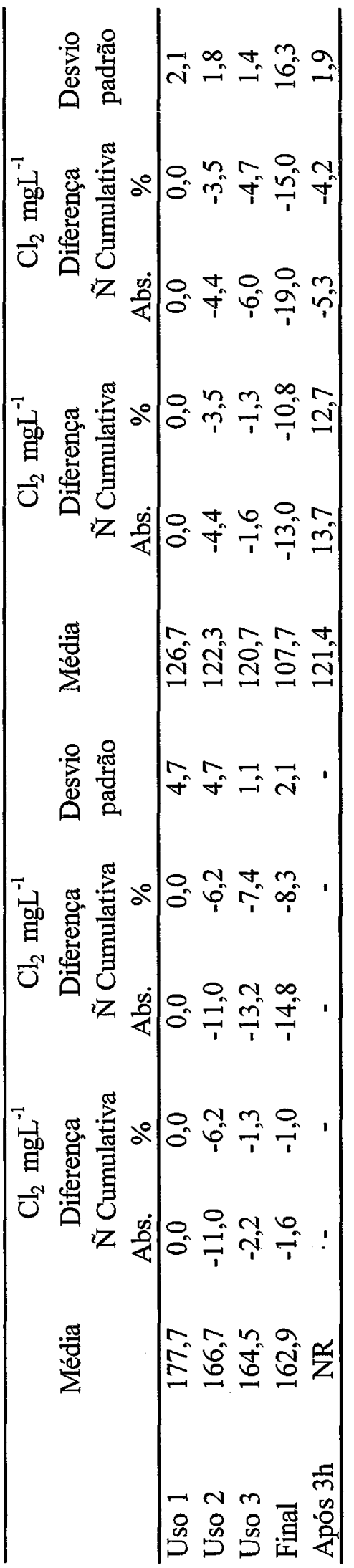




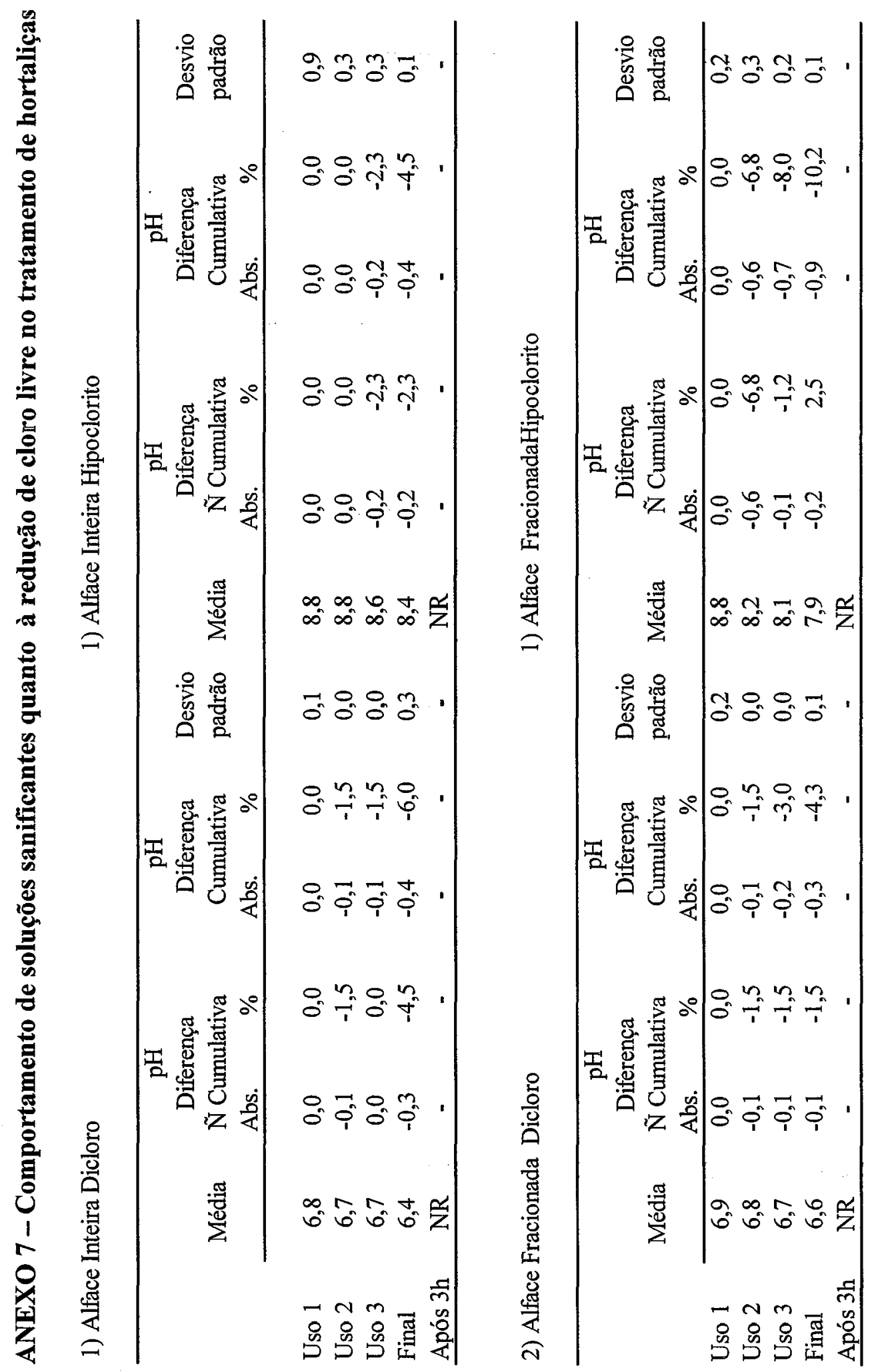




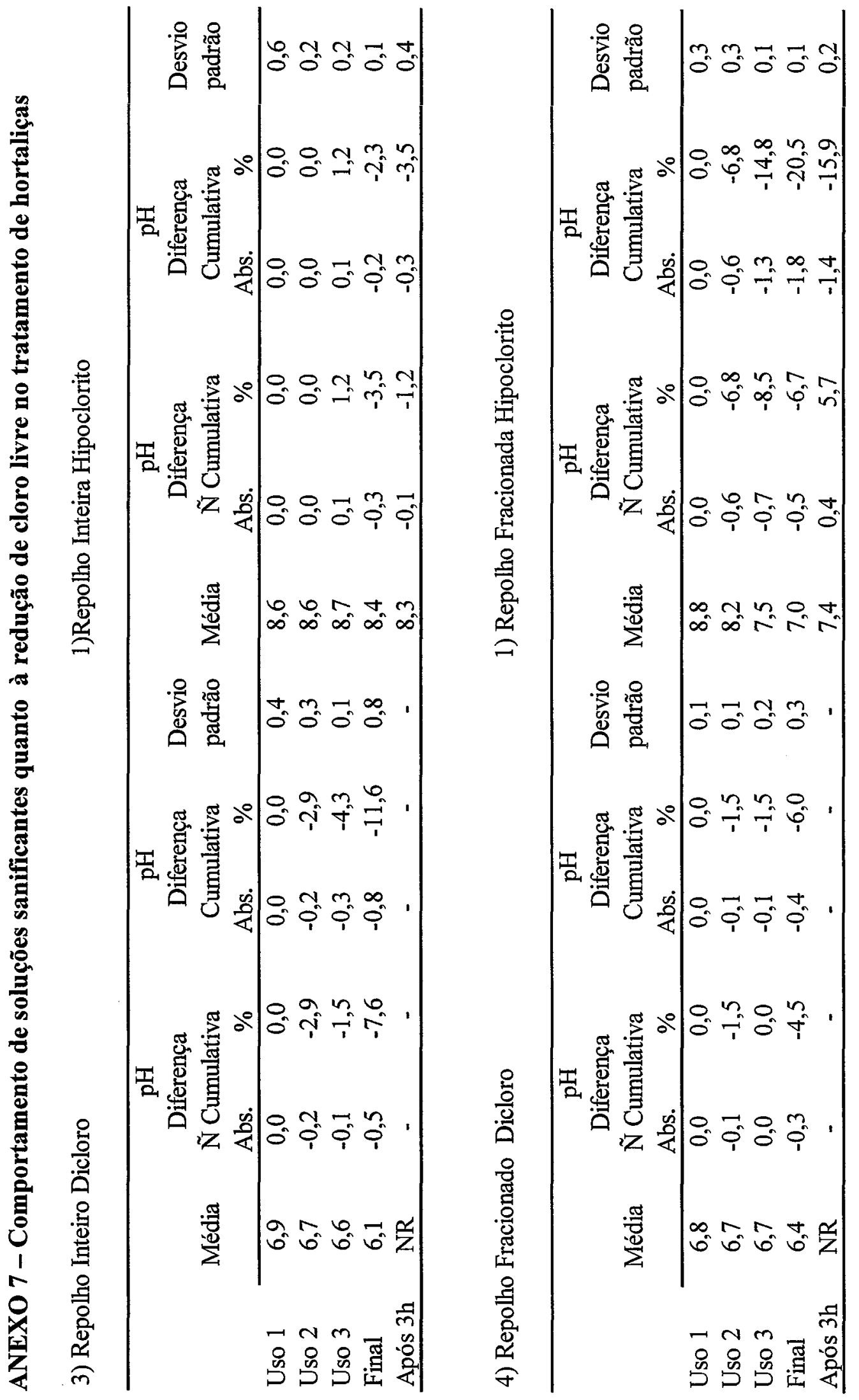




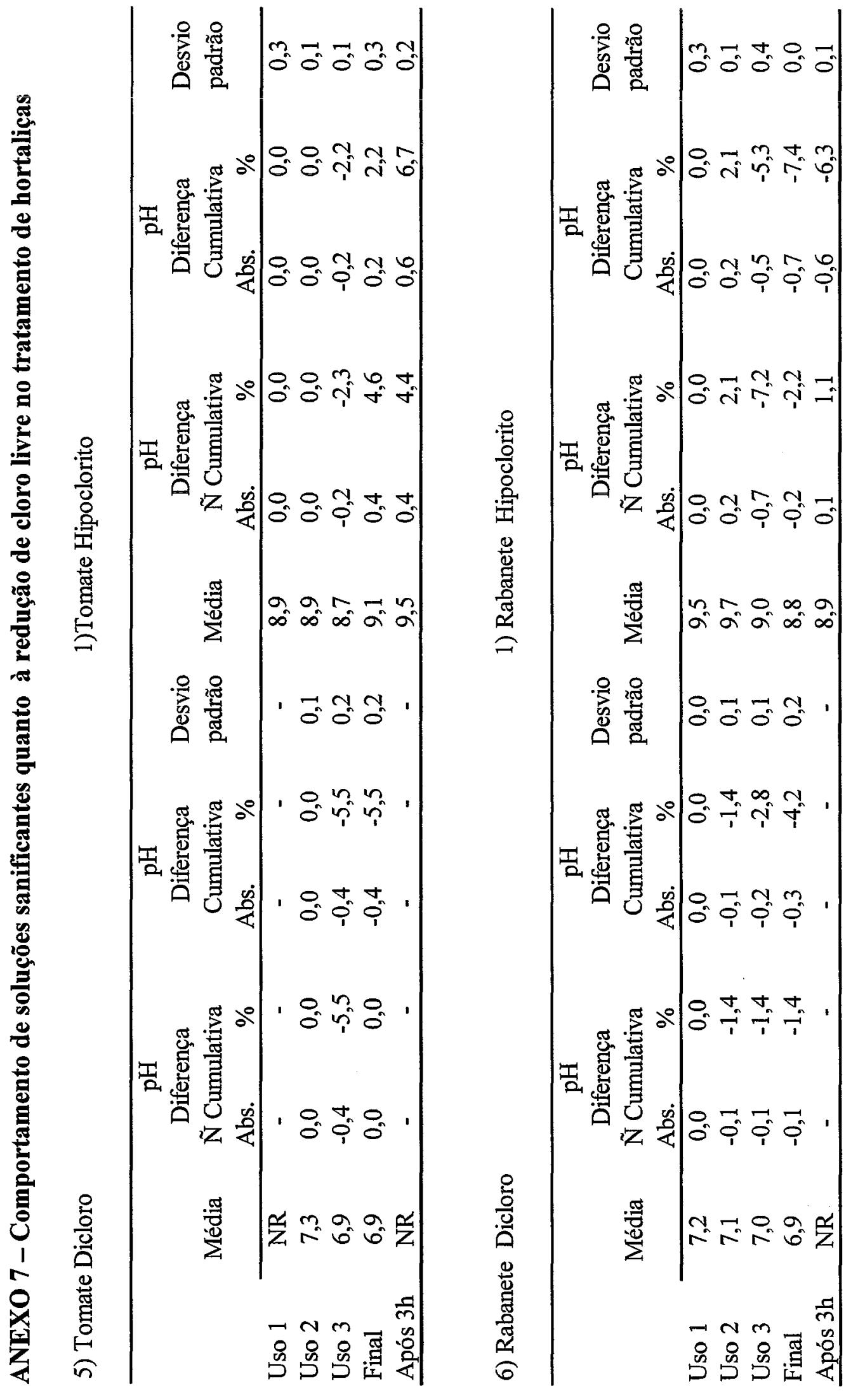




\section{REFERÊNCIAS BIBLIOGRÁFICAS}

ASSOCIAÇÃO BRASILEIRA DAS EMPRESAS DE REFEIÇÕES COLETIVAS (ABERC). Manual da ABERC de práticas de elaboração e serviço de refeições para coletividades. 9.ed. São Paulo, 2001.p.216

ADAMS, M.R.; HARTLEY, A.D.; COX, L.J. Factors affecting the efficacy of washing procedures used in the production of prepared salads. Food Microbiology, v.6, p.69-77, July 1988 .

AGUIAR, C.M.; FERRAZ, G.M.F. de A.; ALMINO, M.G. Avaliação do teor de cloro ativo das soluções à base de hipoclorito de sódio disponíveis no mercado do RecifePE. Pesquisa Brasileira de Odontopediatria Clínica Integral, v.2, n.2/3, p.80-88, maio/dez. 2002.

AMERICAN PUBLIC HEALTH ASSOCIATION. Compendium of methods for the microbiological examination of foods. 3.ed. Washington, 1992. 1219p.

BEUCHAT, L.R.; NAIL, B.V.; ADLER, B.B. et al. Efficacy of spray aplication of chlorinated water in killing pathogenic bacteria on raw apples, tomatoes, and lettuce. Journal of Food Protection, v.61, n.61, p.1305-1311, May 1998. 
BARUFFALDI, R.; PENNA, T.C.V.; MACHOSHVILI, I.A.; ABE,L.E. Tratamento químico de hortaliças poluída. Revista de Saúde Pública, v.18, p.225-234, 1984.

BEUCHAT, L.R. Ecological factors influencing survival and gorwh of humam pathogens on raw fruit and vegetables Microbes and Infection, v.4, p.413-423, 2002.

BLOOMFIELD, S.F.; MILES, G.A. The antibacterial properties of sodium dichloroiscyanurate an sodium hypochlorite formulations. Journal of Applied Bacteriology, v.46, p.65-73, 1979.

BRASIL. Minitério da Agricultura e do Abastecimento. Agência Nacional de Vigilância Sanitária (ANVISA). Resolução $\mathbf{n}^{\circ} 12$ de 02 de janeiro de 2001. Diário Oficial da União, n.7, jan.2001. Seção 1, p.45-53. Aprova os padrões microbiológicos sanitários de diferentes grupos de produtos alimentícios para fins de registro e fiscalização

BRASIL. Minitério da Agricultura e do Abastecimento. Agência Nacional de Vigilância Sanitária (ANVISA). Resolução $\mathrm{n}^{\circ} 12$ de 24 de julho de 1978. Diário Oficial da União, n.8, jan.2001. Seção 1, p.30-33. Aprova as normas técnicas especiais relativas alimentos e bebidas

EIROA, M.N.U.; PORTO, E. Evaluation of different chlorine based disinfectants and vinegar against Vibrio cholerae present in lettuce. Coletâneas do Instituto de Tecnologia de Alimentos, v.25, n.2, p.169-172, 1995. 
EIROA, M.N.U.; PORTO, E. Influência de diferentes tipos de vinagre e do hipoclorito de spodio na sobrevivência de Vibrio cholerae em folhas de alface (Lactucca sativa) artificialmente contaminadas e sobre a microbiota natural. Coletâneas do Instituto de Tecnologia de Alimentos, v.26, n.2, p.199-207, 1996.

FABER, J.M.; ZHANG, S. The effects of varius disinfectants against Listeria monocytogenes on fresh cut vegetable. Food Microbiology, v.13, p.311-321, 1996.

FERREIRA, M. da G.A.B.; BAYAMA, A.B.; MARTINS, A.G.L. de A. et al. Aspectos higiênico-sanitários de legumes e verduras minimamente processados e congelados. Higiene Alimentar, v.17, n.106, p.49-55, 2003.

FRANCIS, G.A.; THOMAS, C.; O'BEIRNE, D. The microbiological safety of minimally processed vegetables. International Journal of Food Science and Technology, v.34, p.1-22, 1999.

FRANCO, G. Tabela de composição química de alimentos. São Paulo: Atheneu, 1987. 230p.

GREENBERG, A.E.; RAND, M.C.; TARAS, M.J. Standart methods for the examination of water and wastewater. Washington: APHA, 1985. 1928p.

HAN, Y.; LINTON, R.H.; NIELSEN, S.S.; NELSON, P.E. Redution of listeria monocytogenes on green peppers (Capsicum annuum L.) by gaseous and aqueous chlorine dioxide and water washing and its growth at $7^{\circ} \mathrm{C}$. Journal of Food Protection, v.64, n.11, p.1730-1738, 2001. 
HURST, W.C. Sanitation of lightly processed fruits and vegetables. Hort Science, v.30, n.1, p.22-24, 1995.

INTERNATIONAL COMMISSION ON MICROBIOLOGICAL SPECIFICATION FOR FOOD. Microorganismos de los alimentos. 2.ed. Zaragoza, 1995. 332p.

JOHNS, N. Higiene de los alimentos: directrices para profesional de hostelería, restauración y catering. Zaragoza: Acribia, 1999. cap.1, p.1-29: Higiene de los alimentos e higiene general.

LAGAGGIO, V.R.A.; FLORES, M.L.; SEGABINAZI, S.D. et al. Avaliação parasitológica da alface (Lactuca sativa) consumida "in natura" no restaurante da Universidade Federal de Santa Maria, R.S.). Higiene Alimentar, v.16, n.97, p.6278, 2002.

LEITÃO, M.F.F. Limpeza e desinfecção na indústria de alimentos. Boletim do Instituto de Tecnologia de Alimentos, n.43, p.26-34, set. 1975.

LEITÃO, M.F.F.; MORAES FILHO, E.; DELAZARI, I.; ANGELUCCI, E. Eficiência de desinfetantes na redução da contaminação bacteriana da alface (Lactuca sativa L.). Boletim do Instituto de Tecnologia de Alimentos, v.18, n.2, p.201-226, 1981.

MACEDO, J.A.B. de. Águas para piscinas: importância do processo de desinfecção em água de piscina. Jan./Fev.2002. http://www.crq4.org.br (27 mar. 2003) 
MACEDO, J.A.B. de; BARRA, M.M. Derivados clorados de origem orgânica uma solução para processo de desinfecção de água potável e para desinfecção de indústrias. /Apresentado ao 6. Simpósio Ítalo Brasileiro de Engenharia Sanitária e Ambiental, São Paulo, 2002/

MARRIOTT, N.G. Principles of food sanitation. New York: An Avi Book, 1985. 290 p.

MARTINS, E. C., KUAYE, A.Y. Emprego do ácido peracético e outros sanitizantes na industria de alimentos. Higiene Alimentar, v.10, n. 43, p.5-8, maio/jun. 1996.

MAZZA, G. Alimentos funcionales-Aspectos bioquímicos y de procesado. Zaragoza: Acribia, 2000. 457p.

MENG, J.; DOYLE, M.P. Introduction: Microbiological food safety. Microbes and Infection, v.4, p.395-397, 2002.

MOKGATLA, R.M.; GOUWS, P.A.; BRÖZEL, V.S. Mechanisms contributing to hypochlorous acid resistance of a Salmonella isolate from a poultry-processing plant. Journal of Applied Microbiology, v.92, p.566-573, 2002.

NASCIMENTO, A.R.; M FILHO, J. E.; BAYAMA, A. B. et al. Sanitização de saladas "in natura" oferecidas em restaurantes self-service de São Luiz, MA. Higiene Alimentar, v.16, n.92-93, p.63-67, 2002. 
NASCIMENTO, M.S.; CATANOZI, M.P.L.M. Avaliação comparativa de tratamentos químicos na sanitização de frutas e hortaliças. Araraquara, 2002. 79p. Dissertação (Mestrado) - Faculdade de Ciências Farmacêuticas, Universidade Estadual Paulista "Júlio de Mesquita Filho".

NASCIMENTO, M. da S.; SILVA, N. da; CATANOZI, M. da P.L.M. Emprego de sanitizantes na desinfecção de vegetais. Higiene Alimentar, v.12, n.112, p.42-46, 2003.

NEVES, M.F.;CHADDAD, F.;LAZZARINI, S.G. Alimento: novos tempos e conceitos na gestão de negócios. São Paulo: Pioneira, 2000. 98p.

NGUYEN-THE, C.; CARLIN, F. The microbiology of minimally processed fresh and vegetables. Food Science and Nutrition, v.34, n.4, p.371-401, 1994.

NGUYEN-THE, C.; PRUMIER, M. Involvement of pseudomonas in the deterioration of "ready-to-use" salads. International Journal of Food Science and Technology, v.24, p.47-58, 1989.

NICOLETTI, M.A.; LÓPEZ, M.F.B.; MAGALHÃES, J.F. Determinação do prazo de validade de soluções comerciais de hipoclorito de sódio expostas a níveis variáveis de luminosidade. Revista do Instituto de Ciências da Saúde, v.13, n.2, p.59-62, jul./dez. 1995.

NICOLETTI, M.A.; MAGALHÃES, J.F. Influencia del envase y de factores ambientales en la estabilidad de la solución de hipoclorito de sódico. Boletín del Oficina Sanitaria del Panamá, v.121, n.4, p.301-309, out. 1996. 
NOGUEIRA, M.; SCHOCKEN-ITURRINO, R.P. Avaliação da qualidade higiênicosanitária de hortaliças produzidas e da água de irrigação e lavagens em hortas da cidade de Jaboticabal-SP. Jaboticabal, 2002. 56p. Dissertação (Mestrado) - Faculdade de Ciências Agrárias e Veterinária, Universidade Paulista "Júlio de Mesquita Filho".

OLIVEIRA, C.A.F. de.; GERMANO, P.M.L. Aspectos sanitários da contaminação de hortaliças por enteroparasitas. Comunidade Científica da Faculdade de Medicina. Veterinária e Zootecnia da Universidade de São Paulo, v.16, n.1/2, p.27-32, 1992.

OLIVEIRA, E.C.M.; VALLE, R.H.P. do. Aspectos microbiológicos dos produtos hortícolas minimamente processados. Higiene Alimentar, v.14, n.78/79, p.50-54, 2000 .

PAIVA, J.G. de; GUTZ, I.; SAMPAIO, J.M.P.; SIMÕES, W. Determinação do teor de cloro livre nas soluções de hipoclorito de sódio. Revista Brasileira de Odontologia, v.46, n.1, p.10-16, jan./fev. 1989.

PARK, C.M.; BEUCHAT, L.R. Evaluation of sanitizers for killing Escherichia coli O157:H7, Salmonella, and naturally occurring microorganisms on cantaloupes, honeydew, melons and asparagus. Dairy Food and Environmental Sanitations, v.19, n.12, p.843-847, May 1999.

PINTO, G.; ROHRIG, B. Use of chloroisocianurates for disinfection of water. Journal of Chemical Education, v.80, p.4-44, 2003. 
PORTO, E.; EIROA, M.N.U. Listeria monocytogenes: ocorrência em hortaliças, resistência aos sanificantes e sobrevivência em alface (Lactucca sativa) minimamente processada e acondicionada em atmosfera modificada. Campinas, 2001. 188p. Dissertação (Doutorado) - Universidade Estadual de Campinas.

PRATA, L.F. Higiene de alimentos e as necessidades contemporâneas. Higiene Alimentar, v.14, n.74, p.13-16, 2000.

PREGNOLATO,W.; PREGNOLATO, N. Normas analíticas do Instituto Adolfo Lutz. São Paulo: Instituto Adolfo Lutz, 1985. 533p. v.1.

RICHTER, C.A.; NETTO, J.M.A. Tratamento de água. São Paulo: Edgard Blücher, 1995. 332p.

SANT'ANA, A.; AZEVEDO, D.P.; COSTA, M. da et al. Análise de perigos no processamento mínimo de vegetais. Higiene Alimentar, v.16, n.101, p.80-84, 2002.

SÃo PAULO (Estado). Portaria CVS-6 de 12 de março de 1999. Diário oficial do Estado, 12 mar. 1999, v.109, n.47, p.24-27, 1999. Seção I. Aprova o regulamento técnico sobre os parâmetros e critérios para controle higiênico-sanitário em estabelecimentos de alimentos.

SAPERS, G.M.; SIMMONS, G.F. Hydrogen peroxide disinfection of minimally processed fruits and vegetables. Food Technology, v.52, n.2, p.48-52, Fev. 1998.

SILVA, N.; JUNQUEIRA, V.C.A.; SILVEIRA, N.F.A. Manual de métodos de análise microbiológica de alimentos. São Paulo: Varela. 2001. 300p. 
TAKAYANAGUI, O.M.; OLIVEIRA, C.D.; BERGAMINI, A.M.M. et al. Fiscalização de verduras comercializadas no município de Ribeirão Preto, SP. Revista da Sociedade Brasileira de Medicina Tropical, v.34, n.1, p.9, 2001.

TORRES, E.A.F.S. Estudo das propriedades desinfetantes do ozônio em alimentos, Higiene Alimentar, v.10, n.42, p.18-23, 1996.

WILEY, R.C. Frutas y hortalizas minimamente processadas y refrigeradas. Zaragoza: Acribia, 1997.250p. 